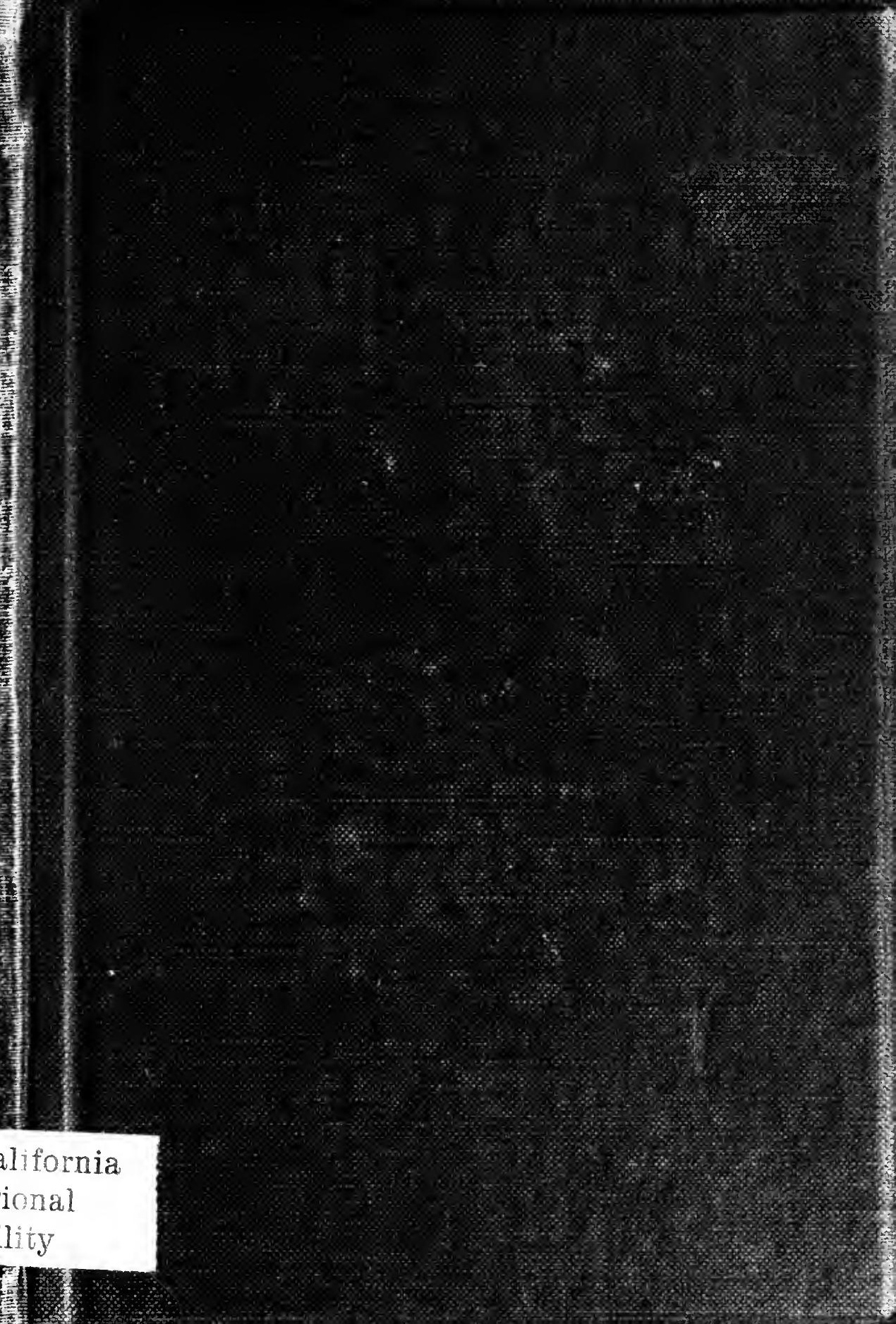


Digitized by the Internet Archive in 2007 with funding from

Microsoft Corporation 
UNIVERSTTY of CALIFUREL $A \mathrm{i}$

4.OS ANGELES

LIBRARY 



\section{OCCUPATION THERAPY}

A MANUAL FOR NURSES

BY .

WILLIAM RUSH DUNTON, Jr., B. S., M. A., M. D. Assistant Physician at Sheppard and Enoch Pratt Ifospitals, Towson, MId.; Instructor in Psychiatry, Johns Hopkins University

"Occupation is the very life of life. "-Harold Bell Wright

PHILADELPHIA AND 1ONDON

W. B. SAUNDERS COMPANY 
Copyright, 1915, by W. B. Saunders Company

Reprinterl May, I01 8

Reprinted August, 1025

PRINTEO IS AYIHICA

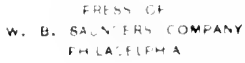




\section{PREFACE}

Tirs little book is the outgrowth of a series of talks which were given to the nurses at the Sheppard and Enoch Pratt Hospital. The manner of its arrangement is based on the course in occupation as it is there given. Yet I have constantly had in mind the nurse in charge of a private case who is responsible for the oecupation of her patient without having an oceupation teacher or director who can advise her as to the best method. I have tried to emplasize the basic principles of orenpational therapy and have given ehiefly those forms of work which may be useful to the private nurse.

It is impossible to give directions for all oceupations and crafts without expanding the book to an abnornal size, and it is merely desired to point the way to the nurse whose inclinations and those of her patient lear to a developuent of special forms. Timerous references are given to books and articles on special subjerts.

1 chapter on the Nurse in the 1Iospital has hem 3 added and points ont the chief differences between the oceupation of a patient in the lospital and one moler. special eare. It is believed that if the nurse hals some knowledge of the origin and history of the work in hand that it may be made more interesting to the paltient. In pursuance of this belief certain interes ing data has heen made a part of the following chlipters. 
The nurse should, howerer, realize that much more of interest may be leaned from other soures. She is uraed to provide herself with an armentarimm which should eomsist at least of the following:

Plaring ards.

I ominoes or card dominoes,

(riblatge board,

Sicrap look with puzzles and catches,

One or more picture puzzles.

and may well include also

$A$ bed table (see p. 121 for directions in making).

Studies in Invalid Ocenpation by Susan F.

Trace. Beston, 1!10. Whiteomb \& Barrows.

She is also ureed to cultivate a particular eraft in order that she may herself have a hobly and also that she ma! have special aldility in instrueting lier patient.

$$
\text { IV. R. Intrex, In. }
$$

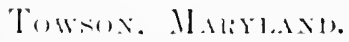




\section{CONTENTS}

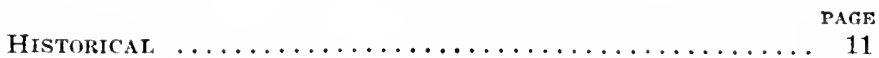

Horbies a.d Thifir Valce . . . . . . . . . . . . 21

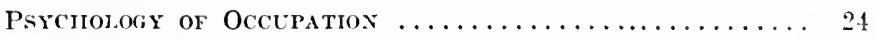

MeCHAXISM OF Reconery by OCCUPATIOX ........... 27

Tine Nurse ix the Hospital ............... 34

Ptzzles, Catciles, Etc. ................. $3 \mathrm{~S}$

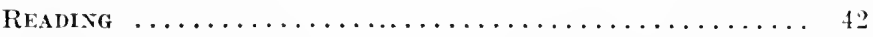

Pitysical Exercistes $\ldots \ldots \ldots \ldots \ldots \ldots \ldots \ldots \ldots \ldots \ldots \ldots \ldots$

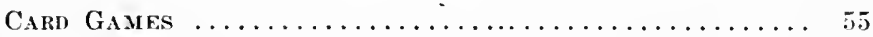

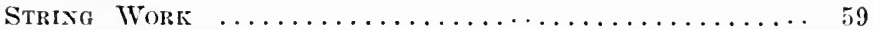

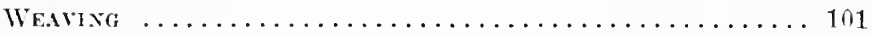

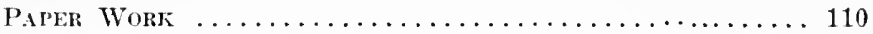

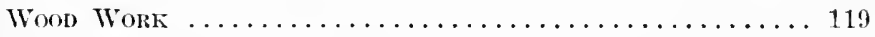

Pictike Plzzles . . . . . . . . . . . . . . . . $12 S$

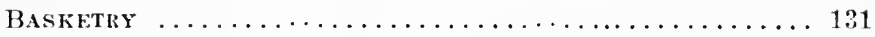

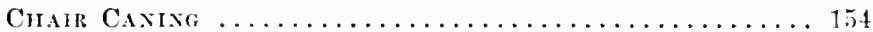

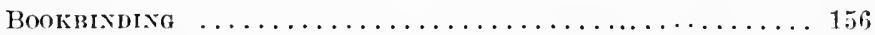

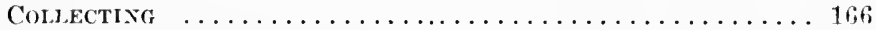

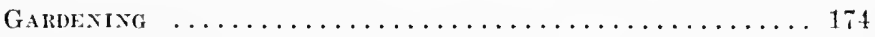

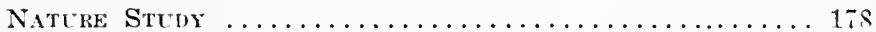

Stexildag axn Block Prixtixg . . . . . . . . . . . 179

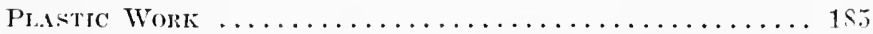

Drawiag axi Pantixg ................... 192

Metal, Wokk ......................... 200

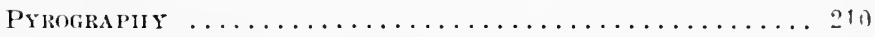

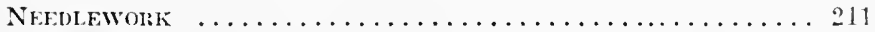

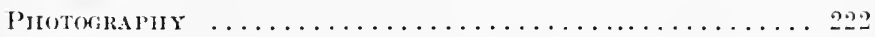

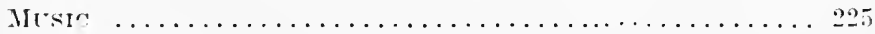

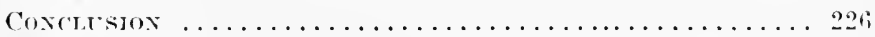

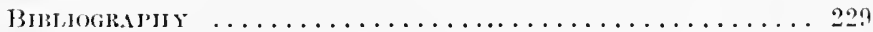

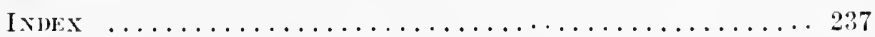





\section{Occupation Therapy}

\section{HISTORICAL.}

While eonsiderable has been written upon the history of ocrupation as a therapentic measure in the care of mental eases, it is impossible to give eredit to any plysician as having been the first to apply it, or to name the form of oeenpation so used. Probably its beginning was so gradual, and yet so general, that it is impossible to give any one person eredit as diseoverer, or dignify any form of ocenpation as having been first nsed to restore a mind diseased. Possibly the eredit helongs to a number of patients, each one of whom found a tranquillizing inthenee in work easually undertaken and so eontinned it in the form originally begmun, or in other ways. The physician, if he was intelligent, noted the cause of the improvement which ensued and alpplied the remedy to other eases. Probably most psuchiatrists past middle age have had such experience. Orcatimally we have had the hig men of peychiatry witinge of their experienees and of the value of ormpation or work as a therapentic measure. Notahle instances 
are Isaac Ray and Lander Lindsay, but too often such opinions have heen buried or dismissed with few words in anmual reports where they are inaccessible after a few rears.

This is proved ly the fact that one of the papers by 1)r. Ray originaly appeared in his report to the Corporation of Butler IIospital for 186.5, and was reprinted in the Joumal of Insamity. 'That other men in other hospitals were alive to the importance of oecupation is shown by the following note for which I am indebted to Miss Edith Kathleen Jones, Librarian at Mrean IIospital: The importance of various forms of diversion, and especially of mamal oceupation, has been rexognized from its (MeLean Hospital) very beginning.

In his report for 152: Dr. Wrman writes, "the anusements provided in the establishment for lumatics, as draughts, chess, backgammon, nine-pins. swinging, sawing wond, wardening, reading, writing, music, etc.. divert the attention from unpleasant subjerts of thonght and afford cexeredse both of body and mind (and) have a powerful offect in tranguillizing the mind. loreaking up wronge associations of icleas and induring correct habits of thinking as woll as acting."

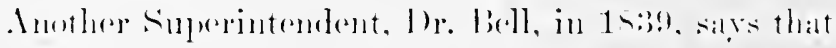

1 Ray, I. Labor in Principal Hospitals for Insane in cireat Lritain. Franee and Germany. Am. Jour. Ins., 1846, 11, 1) :35\%. Ray, I. The Lahor Question and Hospitals for Incurables. Ameriran Journal of Insanity. 1sif, Kxil, 1. 439.

- Lindsay, W. Lander. Reprint form lhe Repert of dames durrays koyal Asylum, Perth, soothant. for 1stin-1. Mhl.

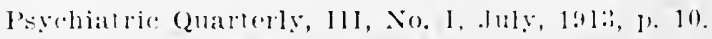


"the experiment of mechanical labour was here first introdnced, and the safety, expediency and immense utility of putting tools into the hands of the patients entirely and satisfactorily decided." And again, speaking of occupation as a means of cure, "there is probably" no other institution in the world where the value of this has been more fully tested than here." Althongh later. owing to the class of patients received at MeLean, meclanical and agrienltural labor was abandoned for "some form of busy idleness," yet each superintendent has done his share in developing this method of treatment. For the men, since 18.34 there has been a carpenter's shop in which woodearving and cabinet making have been taught; while the women lave had lessons in drawing and painting and have done varions forms of fancy-work.

In 18:36, according to the report for that year, 50 patients worked in the carpenter's shop 6 hours a day and nuade $72: 36$ candle boxes which were sold for sinot.06. Iater the boxes were not sold, thongh they contimued to he made. In 1s:;6, " 100 cords of woor were carted hy pationts from what to house, and 200 cords were sawed. split and piled."

$T_{n} 1910$ two roons in the women's armmasiun were preparred for industrial ocenpation of a somewhat ditferent trpe: a teacher of handicratts was engaged. and instruction is now given daily in baskety, leather-work. lalco-making and wearing.

There are now twolve hand lomes. In 1!1:3-1t an addition was built on to the woment sermunatum, pro- 
viding space for these looms. It is well lighted by windows and skylight. Under it is the room used for pottery making, and a kiln has been set up in a disused kitchen. In appropriation has just been made for a similiar enlargement of the men's grmnasium, in order to provide additional oceupations for them. The women are now tanght wearing, basketry (reed and raffia), leather-work (tooling. coloring, making), pottery, modelling, casting, knitting. "rake" knitting, crocheting, embroidery lace-making (pillow and erochet). sewing, bead work, tatting, stencilling, sawing picture pu\%zles, painting (portrait, still life, coloring pictures, coloring cards for holidays).

In the very interesting Descriptive Aecount of the Friends' 1 sylum for the Tnsine. 1A1:-1918, Dr. Robert II. Chase says. "Xo feature in the treatment of the insane is more highly valued than ocenpation, systematically applied and judieionsly carried out. Work is a law of our nature which demands expression in the insane no less than in the sane. To muderstand this one hats only to reflect npon the depresinge effeet of inate tion. then turn to the satisfartion and strength that result from the agrecable use of one's mental and pherient pewers. It maty be seen that from the begimninge

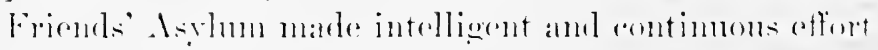
to give the pritients the benetit that enomes from empley-

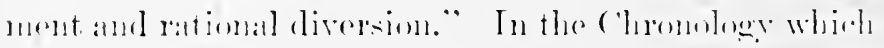
is in the same volume are fomml malny erents beatringe

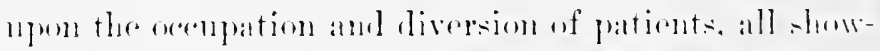
ing that the hropital anthorities were imbled with the 
idea that oceupation was a valuable form of treatment.

Fortunately the value of work, occupation, diversional occupation, or whatever name may be applied to it, in helping the sick mind to recovery has been better recognized in recent years, and with this recognition lias come a desire for a better understanding of how occupation aids and the best ways in which it may he used. This is easily proved by a reference to the bibliography on page 229.

With increased use of occupation it soon became apparent that there must be persons specially trained to carry out this treatment if it is to be sucessful. Credit for first giving systematic training in occupation must be given to Miss Susan E. Traley who gave the first course in Invalid Occupation at the Adams Tervine near Poston in 1906. Soon after, or in 1910, she published her book entitled Studies in Invalid Ocenpation. which has given a great impetus to occupational therapy. Miss Trary's hook was, however, largely written for the teachere of ocenpation courses, and that part which applied especially to the mentally siek was written by Tly. E. Stanley Abbott of the MeTean ITospital. The intreduction, however, by Dr. Daniel II. Fuller, then superintendent of the Adanns Nervine, is an adniralle exposition of how nervons and mental (aises may be benetited lycerenpation.

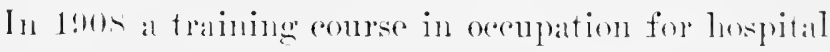

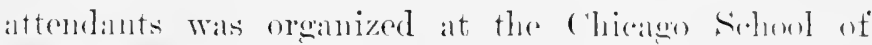
('ivies and Philanthropr. Miss Tulia Lattlone and Rabhi Hirsech had been menulers of the state bealrd of 
Control and had been shocked by the idleness on the wards of the state hospitals. Feeling that public interest should be aroused in state institutions and that surh idleness should not exist, Miss Lathrop and Rabli IIirsch resigned from the Board of Control and organized the course. It was a most execllent one and inchnded inexpensive raflia work with instruction in oldfashioned veast dyeing by Prof. Wartz; book-binding and pasting work; illuminating; stencilling, knotting and weaving; grmnasties and playground work, ete.

The work of Miss Traey so impressed Miss Saral T. Parsons, Superintendent of Nurses at the Massachusetis Creneral IIspital, that in the Spring of 1911 a comrse in orenpation was given at the Training school of that hospital muder Miss Tracy's direction.

I'robully the first nurses' orcupation conrse in a hospital for mental diseases was that wiven at the Sheppord and Finoch Pratt IIospital in the Fall of 1911. A personal note may perlaps be parioned liere. This hospital was first opened for patients in I lecember, 14!1. and in Angust, 15.5. I had the honor to be appointerd an Assistant Physician, and have been commeted with the hespital to the present. Dr. Edward X. Pimsh. the Superintendent, had alway's recomnized the value of ocenpation als a remedial meisure and hatd done all that he could to furtleer it ly giving pationts fac ilitios in the

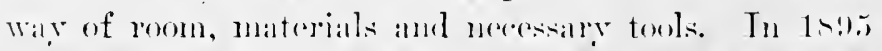
one man had quite a well-titted shep for netal workinge.

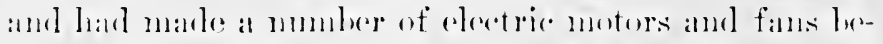

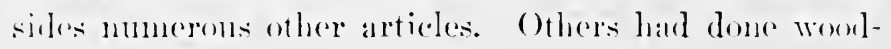


work. Another man had assisted in the ponltry yard. These are but a few of numerous individuals that I recall. A printing office was opened soon after my arrival, which has since become a fixture and is under the entire charge of a patient. Besides doing work for the hospital, a number of charities have been its beneficiaries. In 1903, when raffia work was first introduced, a nurse was sent to learn its use, and in turn tauglit many patients. Dr. Brush had for some time been searehing for a person who was fitted to teach our paltients some arts and erafts, and in 190.5 found a properly qualified instructor in Miss Grace E. Fields. T"nder her instruetion beautiful specimens of copper, leather and weaving were made by patients, and gradmally more homely oceupations were arlded. Some of her especially interesting experiences have been recorded by Miss Fields in the American Joumal of Insanity. ${ }^{1}$ Regular classes in such oecupations as looklinding, steneilling, lloek printing, metal work, wood work, illuninating. needle-rork, reed and raffia work. wealving, ete., have been and are being given. There are at present eleven teachers, of whom two give their full time and the remainder part time to this work. Occupation is regarded as one of the most valued theratpentic measures. I library, with a librarian in rewnlal attendance. and regular lectures. concerts, ote. als well als athletices of varions sorts, afford different varieties of

1 Fields, Grace E. The Effect of Ocrupation rpon the Individual. American Journal of Insanity, IxrII, July, 1!11, p. $11 \% 3$. 
oerupations. This personal aleoment is given in order that the reader may appreciate the value which is placed upon ocerpation hy those charged with the cure of mental diseases.

Alout the same time and during the same month (Octoler. 1911). Miss Rieba G. Cameron, Superintendent of Turses at 'Tamnton State I Iospital, began a course in oecupational training for her murses. Miss Cameron hias no record of the exact date of her first class, and as that at the Sheppard and Enoch Pratt Hospital was given ()etober 10.1911, she has very eraciously waived any raim to priority. Miss (ameron has an admirable method of instruction. Bolieving: as do many of 11. that occupation is the most valuable therapentic agent in the care of the insane, she personally gives this (omrse to the jumior murses, in ordor that they may early in their training realize its inportanee, and that the fationts may also benefit ly laving trained attention. six murses are given instruction in the morning and in the afternoon each nurse instructs a gromp of pationts in the same form of work. This method is sald to work admiralily.

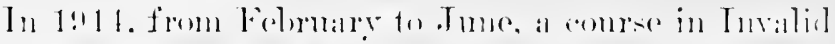

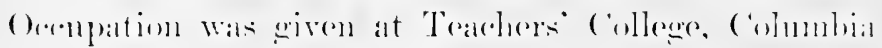

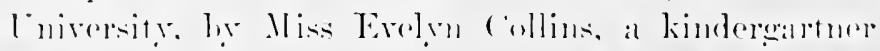

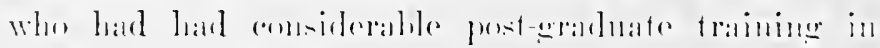

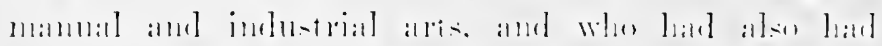

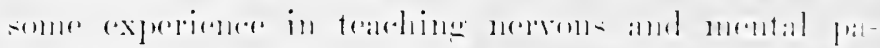

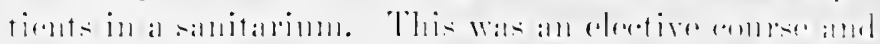

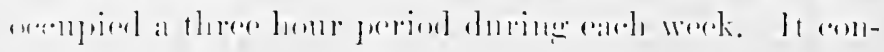


sisted of lectures, practical work and demonstrations of the forms of handieraft which have been found to be most popular. This course is given each year.

At the Jolns IIopkins Ilospital, as a part of her training, the nurse is on duty for three months at the Menry Phipps Psychiatric Clinic, during three weeks of which she is given special instruction in oceupation by Mrs. Eleanor Clark Slagle, ${ }^{1}$ who has had extensive experience in this work, having been connected with the Chicigo Sehool of Civies and Philanthropr, and having oranined the occupation work in a number of hospitals. The nurse practically has individual attention for four and a half hours daily, a total of eighty-one hours. She is not taught a number of oeeupations. but thoroughly learns the principles underlying the work. Reed and raffia, simple carpentry, wearing and needle-work are ahont all of the crafts which it is possible to take up in the linited time. The traning which she receives is hroad in that she is tanght that occupation consists of more than craft training, that all forms of diversion and ammsement may he used to aid in the recovery of the paticnt.

It the present time (Tovemher. 1911) these are all of the training courses in which oceupations are inchoded that are known to me. I number of hospitals and sanitaria, however. train their murses in a lese fou-

1 Since the ahove was written Mrs. Siagle has talen charew of the Oerupational centre of the Illinots Nental Hyeneme

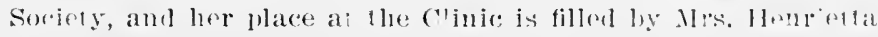
G. P'rice. 
mal and, unfortunately, less thorough way, the murse acquiring what she may through observation. It is practically impossible for her to gain a knowledge of hasic principles under these circumstances, and a lecture or two early in her training would be of a great help to both her and to the patients nuder her charge. It is generally conceded that oceupation is the most valuable single therapentic anent that we have in the (are of the mental and nervons sick, and it seems but reasomable that the nurse, who am aid so much in its application, should be tanght its principles early in here conse. 


\section{HOBBIES AND THEIR VALUE.}

On the other hand, there are quite a number of alble psychiatrists who do not place so high a value upon oecupation. In most cases this seems to be due to the fact that not personally having a liking for mannal work of any sort they cannot appreeiate how much it may mean to others. The eriticisms of some of these men have been most helpful to those of us who value occupation, as it makes us more critical of our own work.

IVith lut a moment's reflection it can readily lo understood that an ocenpation which will appeal to one individual will not to another. We probably all know a professional man who has as a hobly gardening, or perhaps photography or carpentry. I dentist of $11 y$ acquaintance makes clocks. In oculist spends his spare hours during the winter in making a tishing rod. which he tries ont during his summer vacation.

Those who have read the Vailimal Tetters of Rohert Louis Stevention may recall that in one of them he speaks of haring exhalusted himsolf phrsically by doing some garden work which he might have had some one else do for six pence while le wats eaming almost als many pounds by lis writing. This hals always reement to we to be all excellent illustration of how strone the craving for a mannal oecupation may be in a mental 
worker. Tere was Stevenson in the last stage of consumption, a man pre-eninently doing intelleetual work, deriving great pleasure and satisfaction from going out and weeding lis garden for a conple of hours. Persomally, I know that after my day's work at the hospital an hour or two in the garden with cultivator or hoe will often relieve me of a headache when resting upon the poreh will not. The physiological explanition is quite simple. We all know that blood flows in an increased quantity to the organ that is aetively functioning, its need of nourislmont and the exeretion of waste products being areater; therefore, it is but natural that after a prolonged period of mental activity the brain cells should experience a certain amount of fatigne of which we are conscions, and by muscular aetivity we not only give our lrains a rest from mental work by ceasing to do it, but we relieve the cells of actual physieal work by diverting the increased hlood current to other organs. It would be easy to find instances of this desire for a elange in the form of work. and "The Inoblies of Cireat Men" would make a very entertaining study: It would eertainly be interesting to compare the different methods they lad of coming off their perdestals. We are apt to invest our heroes with halos and ansider them as belonging to a rale different from colrolvers on that it is comforting to find that they are

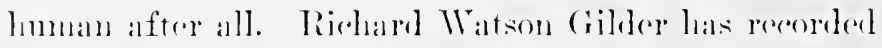

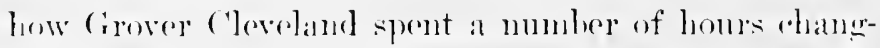
ing a broken multiplying red to a simple one. Ho

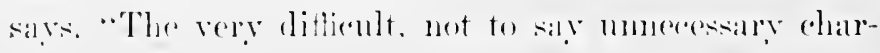


acter of the labor (he must be the possessor of twenty reels in all:) appeared to give him pleasure, and nothing more than the production of something simplethat quality so characteristic of his mental habit."

But another indiridual may prefer music. or to study the Latin poets, as does one celebrated neurologist. In other words, an intellectual occupation is desired rather than a manual one. Sometimes we ean hardly dignify the hobby by the term intellectual, as the late Chief Justice Fuller relaxed by reading dime novels, and an eminent internist during his vacation reads the light novels which have been published during the previous winter.

Those having it, whatever the hobby may be, are fortunate in having something which serves them as a safety valve and prevents their brooding and worrying over the petty amoyances of the day"s work.

We must, therefore, study earefully to learn what form of oceupation is most suitalle for our patient, and if $n$ specific directions have been given by the phy- $^{\text {thy }}$ sician it is the duty of the nurse to do this. 


\section{PSYCHOLOGY OF OCCUPATION.}

It must be remembered that usually the emotions are profoundly disturbed, the patient being depressed, elated or apathetie. Ribot has shown that the power of attention, both spontaneous and voluntary is dependent upon the emotion. and we ean freenuently best help our patient by traning the attention. This can most easily be done ly arousing lis interest in sonething. Which may be accomplished in valrious wirs. Frequently it may he accomplished by asking that something he done as a personal faror (e. g., sopting out eancelled stamps, folding pajers, arranging rlippings, etr.) or that something he made as a gift for one of whom the patient is fond, or by doing something musual in his presence and persuading him to do it. The tact and ingenuity of the numse is often most sererely tested in getting a patient started on oxerupattion. As a rule the effort shomld le direceted to alrouser the patient in something with which he is mufamiliall.

Maving sneereded in arenting onr pationt is attentiom, we must be careful not to do larme be allowing him to berone fatignerl. Wre must remember that his. fereer of fixing his attention is weak, and we must

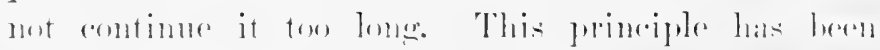

1 The Psychology of Atrention. Translation, 18\%?. The Open court I'ublishing (oo, chicago. 
reeognized by educators for years and is the reason for the short lesson periods with frequent short recesses, and for the short working periods in certain rocations, such as telephone girls and the girls who inspeet the little steel balls which are used to form ball bearings. This fatigue may be aroided by a change of the form of oceupation.

The primary purpose of oceupation may be said to be to divert the patient's attention from mpleasant subjects, as in the case of one depressed. Or in a case of dementia praceox where the subjeet is given to day-dreaming or so-ealled mental rumination, occupation is given to keep the patient's train of thought in more healthy chammels. In a case of mild excitement ocenpation will keep the patient's mind more continnonsly on one subject than is possible if he has not this stimulus to control his attention. In cases of marked exeitement it is usually impossible to use oceupation in treatment which is usually direceted toward securing rest. When convalescence is begm oceupation will be of value.

In cases of dementia of various sorts the purpose may be to re-edncate. to train the patient to develop the mental processes ly edurating the hands, eyes, muscles, ete., just as is done in the developing child.

Another purpose of oceupation may he to give the patient a hohby whieh may serve as a safety valve and render the recurrence of an attack less likely.

Still another purpose which is less often resorted to is that of giving the pationt a means of livelihood after 
leaving the hospital, it heing deemed wise to give up the former rocation. A sehool-teacher, whose visual defect had fored her to give up her position, was so unfortunate as to suffer an attack of depression. During this she was taught basketry and was especially direeted to work by touch rather than by sight, in order to eliminate ere strilin. She dereloped sufficient skill so that her work had a market value.

It is the opinion of some that the patient shomld be instructed in a craft until he lats sufficient skill to take pride in lis proficienery. While this is proper, I fear lest some of its adrocates lose sight of the fact that specialism is apt to canse a narrowing of one's mental outlook, and also that the individual with a knowledge of many things lats more interest in the world in general. I believe it is, therefore, well for the patient to have other oecupations hesides a craft. bearing in mind that orecupation is not restricted to crafts alone. Gamnes, excreises. music, reading. ete., are guite as important. hest is secured and fatigne is avoided by change. The patient should have a major interest and sereral minose ones to direct his thonght in different ehalunels. It is well to adnpt al regular sehedule if the physician dees not anrange one. 


\section{THE MECHANISM OF RECOVERY BY OCCUPATION.}

The mechanism by means of which a recovery is brought about has been the subject of considerable inquiry. It may be summed up by the word substitution, or if one prefers, replacement. It is well known that but one idea can oceupy the foens of the attention at a given time. Our depressed patient who is brooding orer the fancied sin lie believes lie has eommitted pays little attention to what is going on about lim. IRepeated efforts to get him interested in something may fail, but success comes after a time, and we find him watching a baseball game with interest. II is attention is so taken up with the desire for the home tean to make the wimning run that for a little time the depressive idea is driven from the focms of attention, and is replaced by the idea of haseball. Other interests maly be given to him and accepted until at last he regains better control of his attention and can voluntarily drive out the depressive thomehts. Possibly the accompanying diagran which was originated ly Tl. Farrar. and used in amother comnection, may help to make this

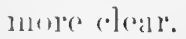

It is helieved that this diagran is of stede value in

1 Dr. Clarence B. Farrar. The Naking of Psychiatric Rereords. American Journal of Insanity, Vol. LXII, p. 479, Jan1:ary, 19mi. 
understanding mental processes that the entire legend which accompanied it in Dr. Farrar's paper is given here, althongh it is somewhat long and is not necessiny in the present instance. We are especially interested in the circle $A$ which represents the focns of the attention or the conscions idea. In cases of depression this circle becomes small, owing to the inability to roluntarily tix the attention. In cases of excitencut the circle becomes enlarged and ideas slip through it with great rapidity. In cases of dementia the circle is ragged and ideas are not clearly formed. A little study, thought and observation will prove these statements. Hence it is easily understood how occupation helps the patient by training the attention.

\section{SCHEMA TO ILLCSTRATE THE PSYCHOLOGIC ANALYSIS.}

Centripetal or sensory paths are represented in blue;

centrifugal or motor paths in red;

central or intrapsychic paths in hlack,

The cereloral hemispheres are represented hy the polygom $\mathrm{S}^{\prime}$ ¿C $\mathrm{II}^{\prime}$.

S any peripheral sense orcan: r. !.. the retina.

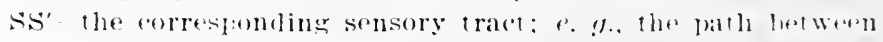
llue retina and ellnelus.

$\mathrm{S}^{\prime}$ - the seat of primary sensation corresponding to the sernse organ S: t. a.e the cortex of the ealearine fisstlre.

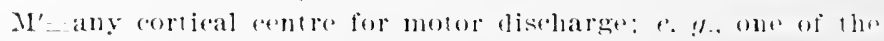
several centres of the proemtral gyrus, or blecos's (onvolution.

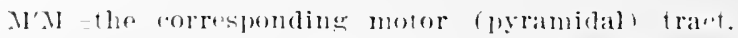

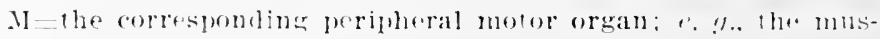
cles of articulate syerech. 
SS'MIII = ihe sensori-motor reflex ars. This is the pure reflex arc which represents the cord reflexes, likewise the reflexes of animals which do not manifest the phenomena of consciousness, and may finally stanil for the first unconscious reflex of the infant.

$A=$ the focus of conscious attention; likewise the seat of identification and interpretation of the primary sense perceptions received at $\mathrm{S}^{\prime}$. A. may therefore be called the seat of secondary sensation, or apperception. A. is also the centre through which takes place the reactive process known as a conscious voluntary psychomotor discharge, or act of the will so called.

$\mathrm{S}^{\prime} \mathrm{A}=$ the psychosensory tract.

Lesions in $\mathbf{S S}^{\prime}$ or $\mathrm{S}^{\prime} \mathrm{A}$ produce respectively peripheral or central

$$
\left.\begin{array}{l}
\text { an- } \\
\text { hyp- } \\
\text { par- } \\
\text { hyper- }
\end{array}\right\} \text { xesthesia. }
$$

$A \lambda I^{\prime}=$ the psychomotor tract,

Lesions in $\mathrm{All}^{\prime}$ or $\mathrm{Ml}^{\prime} \mathrm{Al}$ produce respectively central or peripheral

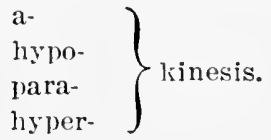

SAM = the psychic reflex arc. the are of normal conscious psy(hosensori-motor activity as displayed in man and in those animals enclowed with associative memory. The broken line is drawn in to separate the higher and lower nervous phenomena,- the fields respectively of psychism and reflex antomatism. Animals possessing only the primary nervous mechanism indicated below the line may be callod protopsychics. those possessing the upper segment as well. mettpsychics. Neural processes involving only the lowel are may be spoken of as pure refleres. those involving the npuer are, as reactions. 
C.- the seats of menory pictures: association centers. Images received at $\mathbf{S}^{\prime}$, interpreted and classified at $A$. may he said to enter into relations with similar images already present in their respective memory centres. C. may therefore be taken to represent the seats of tertiary sensation.

$A$--Border consciousness, the inner circle representing the threshold. The relations to each other of the two circles $\mathrm{A}$. and $\mathrm{A}^{\prime}$. may be illustrated by comparing the inner circle to the pripil of the eye which dilates and contracts, and the area of the outer circle to the iris. Thus images lovering beyond the lhreslyold may le said to become matter of conscions appreciation by the enlargement of the circle $A$. to include them.

$\mathrm{CC}, \mathrm{CA}^{\prime}, \mathrm{CA}^{\prime} \mathrm{ACA}^{\prime}$, etc. $=$ Thought processes. Aets of associative memory. Lesions in these trasts produce

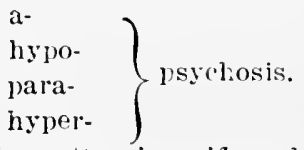

In normal resting attention, if such a condition may be assumed, the status montis may be said to be represented by the schema as it stancls. the focus of consciousness $A$, being in direct connertion with the receiving center $S^{\prime}$ and the discharging centre $\mathrm{N}$ '. The centres of latent menory pictures C1.., on the other hand, while in direct communication with the border of conscionsness $A$ ', as indicated in the diagram, are nevertheless not, in the assumed resting condition. d:rectly connerted with the centre of ronscions attention $A$. (iven this condition, a normal sensori-psychomotor phenom'hon might he deseribed taling place as follows: A primary sonse impression is reepived al $S^{\prime}$ and transmitted to $A$. At this point memory pictures between which and the imfression orenying A. psychic tropisms may be said to exist, are awaliened perhaps at $C:$ and $C$. The ronnections $C: A$ and ('A are at once established and we have the complete

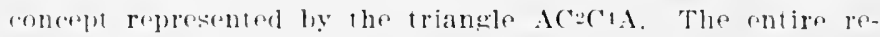
active phenomenon would therefore he indiated thess.- 
$\mathrm{SS}^{\prime} \mathrm{A}$ (AC'CiA) M'M. Such a phenomenon may be called a conscious process.

The concept $\left(\mathrm{AC}^{2} \mathrm{C}^{4} \mathrm{~A}\right)$ has now become a unit and may he represented henceforth perhaps by $\mathrm{C}^{3}$.

If now on the next occasion when a sense impression having a psychic affinity for $\mathrm{C}^{3}$ reaches $\mathrm{S}^{\prime}$, a state of preoccupation be assumed, the psycho-sensory impulse may be stopped at $\mathrm{A}^{\prime}$ and be at once shunted off without traversing A. at all. The reaction may take place in a similar way and we have the phenomenon $\mathrm{SS}^{\prime} \mathrm{A}^{\prime} \mathrm{C}^{3} \mathrm{~A}^{\prime} \mathrm{II}^{\prime} \mathrm{NI}$. This would constitute a subconscious process.

Assuming in the next place a still greater abstraction of consciousness, we may conceive of psychic events which not only do not pass through the focus of consciousness but which do not eren impinge upon the border consciousness, and are therefore perhaps not re-suggestible. Such a phenomenon would be represented by $\mathrm{SS}^{\prime} \mathrm{C}^{3} \mathrm{M} \mathrm{I}^{\prime} \mathrm{M}$, and might be spoken of as a paraconscious process. All the elements of consciousness must be assumed to be variants, and the area of the circle $A^{\prime}$ may vary within wide limits. The processes described as subconscious and paraconscious may differ from each other, therefore, only in degree.

Finally we have the unconscious processes of the regetative and automatic functions, represented by the lower arc $\mathrm{SS}^{\prime} \mathrm{MI} \mathrm{MI}$.

It will at once ve seen how both the variations in normal mentality and the various pathologic states can be graphically represented by slight alterations in the several centres or connecting lines of the sehema. For example, in a normal psychic state the horder consciousness $\mathrm{A}^{\prime}$ may be compared with a filter through which pass to $\mathrm{A}$. only those memory inpressions which have a necessary affinity with the inage at the time orrupying the focus of consciousness, all other memory inages heing repressed in the subconscions sphere. In the state of the so-called maniarel flight. on the other hand. the filterfunetion of $A^{\prime}$ may be said to be defective or al. sent and a sreat variety of centes stands at onee in eonneetion with $A$. This condition wonld be represented by extend-

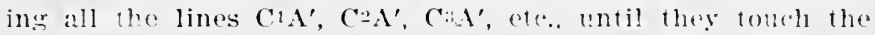




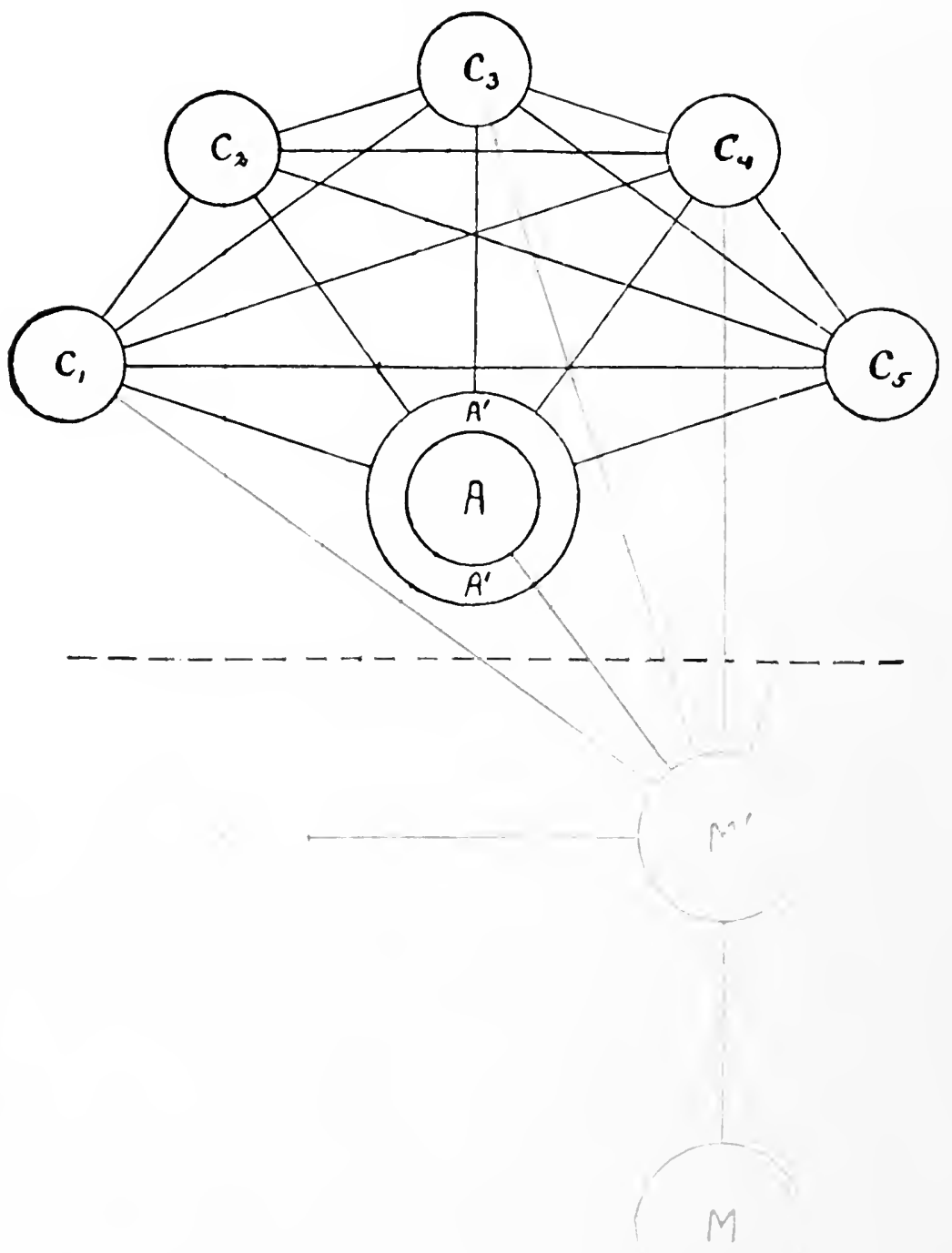

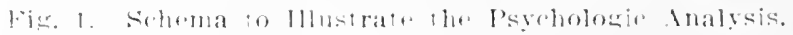


inner circle, or, what anounts to the same thing, hy conceiving the circle $A$. dilated until it coincides with $\mathbf{A}^{\prime}$.

Other pathologic variations will readily suggest themselves.

Aceording to Bertschinger, ${ }^{1}$ reeovery in eases of dementia praecox, or sehizophrenia, as some prefer to call this condition, takes place in three ways, one of which is by desymbolization; that is, subeonseious thoughts are brought into accord with the facts of exterual reality. Surely there is no better way of accomplishing this than by manual occupation. Experience easily proves this, and Dr. Smith Ely Jelliffe, in an admirable article, has recommended that "in the general run, books should be neglected for oceupations in the nature of manual and museular training." Other authors might be eited but it seems mnecessary.

1 Bertschinger, H., Heilungsversuche bei Schizophren. Allgemeine Zeitschrift fuer Psychiatrie. Band 68, 1911, p. 209.

2 Jelliffe, Smith Ely. The Signs of Pre-dementia Praecox: Their Significance and Pedagogic Prophylaxis. American Journal of Medical Sciences, Vol. CXXXIV, p. 157, August, 1907 . 


\section{THE NURSE IN THE HOSPITAL.}

The murse in the hospital has eertain advantages and disalliantages which are not met with by her sister who is specialling a case in a home. Among the first mal be mentioned the possibility of ocenpying the patients in "gangs"-here, eximple is a great incentive. Patients are less apt to sit by idly when their conpanions are working. Then, too, it is much easier to cause patients to forget themselves in games where there is more competition than is possible in twohanded games. In the latter the patient is very apt to think that he has alsolutely no chance to win, and is less likely to make the effort. The chief disadvantage is that there is less opportunity for individual attention. and in certain case's this is especially unfortmate.

["sually in hospitals there is a director" of oceupattion, often one of the physicians, who superintends the varions industries and rrafts, and seleets the kind of ocroupation that the patient shall have. The nurse may feel that this lessens her responsibility in occupying the patient who rofuses to do the work preseribed, but if she is really anderentions she will know that such is not the rase. and if she fails to get a pattient interesterd in a prescriberl oxerupation. it is her duty to diseoser the reasom. and, if pussille. to find another in which the pationt will be interesterl.

In hospitals it is importunt that things should more 34 
on a regular sehedule in order that everything should work smoothly and that there be no confusion. This becomes so much a matter of habit to us that we may fail to realize how beneficial this regular life may be to patients, but it is generally conceded that in the majority of eases, and especially in dementia praecox, a regular life has much to do with improvement or recovery. For this reason it is important that classes or oecupation periods be conducted on a regular schedule. This is usually arranged by the director, but it is the nurse's duty to see that the schedule is lived up to.

The question of rewards is one which is important and concerning which it is desirible to have some accurate information which the nurse ean often obtain better than anyone else. Do patients work with more interest if there is some prize offered? What form should this take? Should it be some tangible tritle or should it be the granting of a privilege? These are hut few of the questions which have been asked and which have not yet been answered anthoritatively. It would seem, lowever, that as a rule the granting of a privilege is better than a small prize. thomgh it may be well to hold an occasional party at which the patients make things in competition for a prize, such ats a box of eandr, ornament, ete. The idea of competition is stimulating to some persons and discomraging to others. so that it seems that a judicions mixtme of the two methods may he best.

In some hospitals there are at times special elasses conducted under the direction of a non-resident teacher 
who is an expert in her eraft. Such a person may in the enthusiasm for the work lose sight of the special ohject of oceupation therapy, which is to develop the initiative of the patient and not to make hin a trained craftsman. The last is a very secondary olject.

It is a good plan for the director or teacher to keep, record of the likes, dislikes, and capabilities of the patients in the form of a card index. $\perp$ form for one of these cards which has been suceessfully used is shown below, but may possibly be better adapted to local eonditions by sone changes. The charge nurse can do much to aid in keeping these cards accurately.

\section{OCCUPATION CARD.}

Name ............ Former Occupation ....... (Indersere oceupations in which patient expresses an interest.) ('rocheting. Sewing, Tatting. Knitting. Brawn-work, (quilting, Embroidery, Wraving....... Other Oceupations! . . . . . . . . . . . . . .

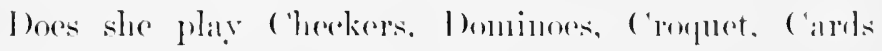
(IIhat (iames)

Has she mosieal ability! ((iive full details.)......

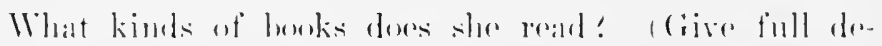
tails.)

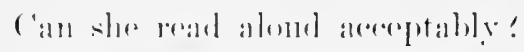

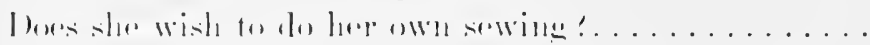

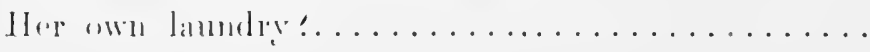


Would patient be helpful in teathing or assisting other patients in classes or groups ?............. Do you know of any other special interest or ability?

(Reverse.)

Does patient write a good hand ?......... Does she need to wear glasses?.......... Is she willing to work in sewing-room, laundry or other department for a half day ?......... For a whole day ? . . . . . .

Make a note of all special requests for materials; of spontaneous efforts at oceupation, or of other facts helpful in planning therapeutic employments.

A record of the patient's attendance, manner of work, interest, ete., should also be kept by the teacher of the particular class attended, and these records should form a part of the patient's elinical history when discharged, as from them may be derived information of considerable value to the physician. It seems better that these should be in the form of frequent notes and comment rather than a set form, as in the latter case much that is of interest may be lost. Miss Field's patper, previously referred to, gives an admirable example of what may be done. 


\section{PUZZLES, CATCHES, ETC.}

It will be well for the nurse to start her oceupation armamentarium by collecting a number of catches and puzzles and placing them in a scrap-book, which she is directed to make later on page 160. Their espe"ial value is that they may be used to first muage the attention of the patient, canse him to take an interest in the nurse, and accept more willingly the suggestions made for other forms of oceupation.

Pieture puzzles, the disseeted or cut up pictures, which have heen so popular in present years are always of ralue and should he freely used. lireetions for making them will be found on pages 12s-1:30.

The following atches are offered becalse they have been found usoful. but there are a great number which are as good and which the nurse may find to be as uneful.

If the lint mint :

If the li . putting :

Ins-If the grate be (erreat $T$ ) empty put conal on (colom). If the grate he full. stope (period full stop) putting (ool ons.

To whom and where womld the postontioes somd a letter addrexiol thins:

$$
\begin{aligned}
& \text { Mrowed } \\
& \text { Johnt } \\
& \text { Malss }
\end{aligned}
$$

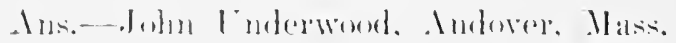

$$
34
$$


What did the Frenchnin mean when he wrote these?

$$
\begin{array}{ll} 
& P \\
\mathrm{~J} & \mathrm{~J}
\end{array}
$$

Ans.-Jai a-petit. Jai somper (sous p).

If you know that your patient is somewhat familiar with Latin, he may lo asked to translate the following:

I Sabilli, leeres ago

Fortibus es in aro

Nos es billi Thebe dux

Buthew usent. Thewust rux.

Ans--I say, Billy, here's a go,

Forty lusses in a row.

No, sez Billy, they be durks.

But they wisn't; they was trucks.

Ilow do you pronounce Phtholognyrrh?

Ans-Tumer. Phth=T as in phthisis, ole ar ats in "olonel. gn= 11 as in ginat, yrrh=er as in myrrh.

\section{MATCH PUZZLE.}

1 good puzzle game can be played with matchess. It will eallse a great deal of anusement. The thestims to be solved ane these:

1. Arrange ten matches so als to make at mam ont of them.

$\therefore$ ()ut of eleven matches make wire. 
3. Arrange ten matehes so as to make a monkey out of them.

t. Take nine matches and make a donkey out of them.

5. Turn eleven matches into seven dozen.

6. Make a loat out of seven matehes.

7. Arrange ten matrhes so as to make only two.

S. Make a tub out of seren matches.

Ans.- The matelies are arranged to form letters and words. Thus the answer to 1 is M MI. four matehes forming the $\mathrm{X}$ and three for both 1 and $X$, a total of ten. The only exception is 6 . where a crude boat is outlined. I further eateh is the substitution of a synonym in : and t, as APE for monkey, and ASS for donkey. The answer to 5 is expressed in Roman unmerals, as LXXXIV. (See Fig. 2.)

\section{WHAT CITIES ARE THESE?}

.1l of these are eities in the T". S. exoept 17, 18 and 23. 17 is in China, 18 in Great Britain, and $2: 3$ is in Aralial.

1. Where all have been.

2. A great engineering feat.

3. An improvement on the ship which grounded on Momnt Ararat.

4. A military defence, and a Paris dressmakir.

5 A rity whose end and aim is 5. Chicago. "go."
1. Boston.

2. Wheeling. West Virginia, on the Ohio.

A. Newark.

4. Fort Worth. 


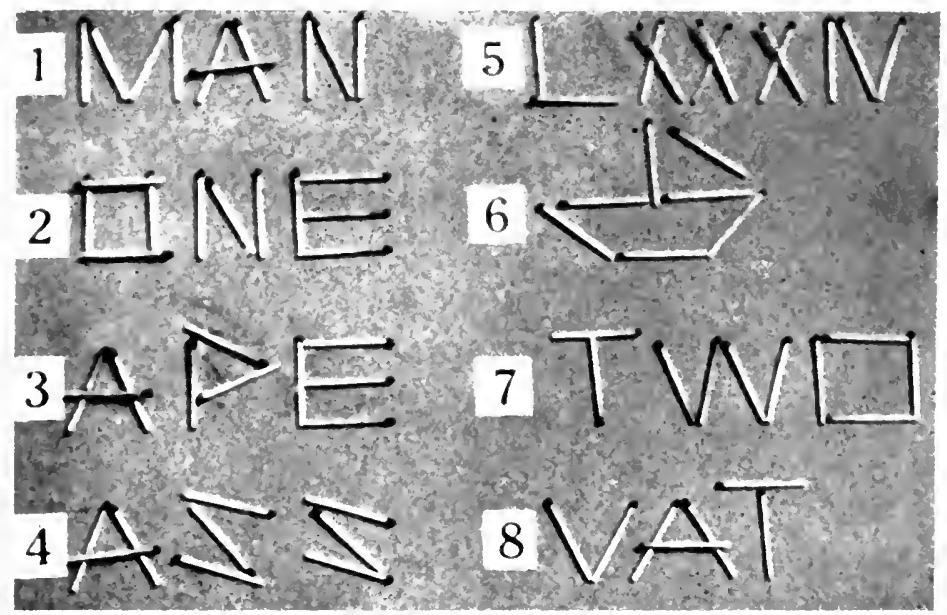

Fig. 2. Answers to Mateh louryles. 


$$
\text { , }
$$


6. Our board of city fathers, also a 6. Council Bluff. precipice.

7. An accldent whlch results in a 7. Sioux Falls. ducking.

8. An exclamation, an appeal to 8. Omaha. maternity, a laugh.

9. An opera encore.

10. Named from the king of France

9. Sing Sing. who reigned from 1226 to 1270 A. D.

11. A deceased farmer who was twice dictator of Rome.

12. Named for an ancient city whose downfall after a long seige avenged the abduction of a woman.

18. A place for the lingerers.

14. A famous father.

15. A high place, and what all children love.

16. A superlative and rushing 16. Grand Rapids. water.

17. A girl's nickname, and rela- 17. Nankin. tions by blood or marriage.

18. A purely American product, and 18. Cornwall. a continuous structure.

19. A girl's name, and a Roman 19. Saratoga. garment.

20. Harmony.

21. Not a short twig.

20. Concoril.

21. Long Branch.

22. Divide the soil.

22. Cleveland.

23. A noted blade.

23. Damascus.

24. A match of the ollen time.

24. Flint.

25. Unparalleled surgery.

25. Lansing.

26. Adam's Ale.

26. Clear Water.

These last two series are exerellent herante they lead the solver on from one to the next. 


\section{READING.}

It is very important that the nurse learn to read well. If her voice is harsh or shrill, or her pronunciation is had she should strive to orereome these defects. The first by listening to other's speak and so edueating her ear to detect what tones, inflections, etc., are pleasing and unpleasant and then by listening to herself correct her faults after noting them. In reading, as in singing, the simplest and probally the best method is to listen to one's self rather than try to achieve the mechanical stunts in which some teachers delight. If the nurse notes that she is prone to mispronounce words she should regularly read the dictionary and so learn their proper accentuation. Although, like the Irishman, she may find it rather "desnltory" reading.

The choice of what is to be read must be left to the nurse's tact, and it is very difficult to give any general rules which will apply to the majority of cases. Sometimes when the patient is mute and depressed the physician orders the nurse to reald for half an hour from a certain hook, possibly a dull one. The recurrence of this cach day at a regular time may finally irritate the patient. who wishes to be mudisturled in his misery, so that he begs the nurse to stop. when a bargain can be made that he shall speak. Or, the book heing less dull. the patient may gradually show an interest, even beg for a longer reading. to leam if the villatin really gets 
her. Tere lie may be persuaded to read to himself, or some other advance may be gained. About the only rule that can safely be made is that the book must be entertaning, and even this only applies when the reading is done for diversion and not for a special purpose. such as is noted above. There are so many good books that a choice does not seen difficult, but when actually confronted with the necessity of picking out a volmme which will annse or divert and yet not contain anything which will bring up an unpleasant association. the task becomes difficult. One would hardly pick out the "I.unatic at Large," and yet it would be much more entertining and diverting to a peevish lady who has become depressed through having alienated her husland than would a "sweet pretty" love story. The nurse should know sonething alout the book she reads either from her own or others' knowledge of it. In a hospital the librarian is alle to give information about suitalle looks. When there is no librarian to consult, the murse's tact must aid her in a choice, althongh she will get much help from a list conpiled by Miss Jones, entitled, "A Thonsand Pooks for" the Tospital Lilirary," the foreword of which rontains many helpful hints and which is also intersporsed with brief comment on the works named.

There are a mumber of hooks, poems, ete. which may be helpful to patients. Olie who was depressed said

1 Jones, Edith Kathleen. A Thousand Books for the Hospital Library. 1913. American Library Association Publishing Board, 78 E. Washington Street, Chicago. 25 cents. 
that what started her on the road to recovery was reading "Success comes in cans, failure in can'ts". in the daily motto frame on her ward. The following poem might he helpful, especially if the book of the same title should be on hand.

\section{EVERYBODY IS.}

Way down deep within their hearts

Everybody's lonesome.

Far within their secret parts

Everybody's lonesome.

Makes no difference how they smile,

How they live or what their style:

Once in every little while

Everybody's lonesome.

People first in big affairs-

Even they are lonesome.

llaybe like to put on airs:

Just the same, they're fonesome.

Men for whom existence blends

Every good: who gain all enls,

Still reach out their hands for friends;

Everybody's lonesome.

Women, silk-clad, jeweled fine.

Yes, they, too, are lonesome.

When their grems the brightest shine,

They are just as lonesome,

Some must serve and some commant

All still seek, with groping hand,

Love, and friemls whe l'vilkstixis;

Everyludy's lonesome. 
Though your gift of friendship's small, Everybody's lonesome.

It may answer someone's call;

Someone who is lonesome.

Give and give with might and main,

Give your hands and join the chain;

And your gift will be your gain,

Some time when you're lonesome.

- Detroit News.

It is difficult for us to realize how much the emotion fear enters into and controls our daily lives because ats arule it is subconscions and we do not recognize it without thought and self-exanination. We do not speak to the stranger beside us on the cal because we fear that he will think us presuming, or may answer in a way to humiliate us or hurt our feelings. We do not leelp the old woman pick up the rontents of her spilt market basket heeanse we fear lest we appear ridiculous to some passing acquatintance. It is fear which canses many people to become reserved, stiff, dignified, ete. It also "auses many young people to berome what l)r. Iforh has alled "shut in." That is, they are afrail to express their enotions lest they be ridionled. and aradually, as a refuge from their lonely isolated life. they hegin to live a drean life and in time al provehosis. denentia pracenx. derelops. Sometines a boxk, such is "Everylordy"s loneseme" or something olse which maly he read, may make an impression and lead to at more healthy manner of thomght.

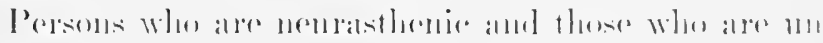
der the inthence of some healing fald, such als (hris 
tian Scienee, New Thought, ete, may be lead into normal ways of thinking by reading a little book ealled "The Conquest of Nerves" 1 by Dr. Courtney. There are quite a number of other books which may aid patients in mental training such as those by Annie Payson ('all, ${ }^{2}$ and others. ${ }^{3}$

Mental development may be fostered also hy a reading course, or if the patient is able, by some course of study perhaps. 'The nurse nust remember, however, that she is not a teacher but a fellow student, and this attitude should be held no matter what form of work or play is going on. Participation is emphasized by Miss Tracy and is a cardinal principal.

It is an excerllent plan to have some form of reading matter within reach of the patient so that he may amuse himself if he so desires. The illustrated periodicals are esperially useful for this purpose.

I reading rourse in the history of art. or of buglish or American literature, may do much to awaken the convalescent patients' interests. 'There are many books

1 Courtney, .J. W. M. I). The Conquest of Nerves. New York, 1911. The Narmillan ('o.

a Call, Annie Payson. Power Through Repose. As a Matter of course. The Freedom of Life. Boston, Little. Brown and company.

$\therefore$ Cahot. Richard $\therefore$ What Men live IBy. Work, May, Iowe. Worship. Boston, 1914, Houghton, Miflin Co.

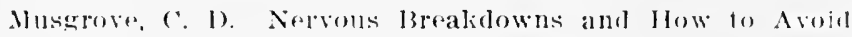
Them. Now York, 1914, Funk \& Wagnalls co.

Walton, Geo. L. Why Worry? Phila.. J. I3. Lippineott Co. Same. Those Nerves. Phila., d. B. Lippineott Co. 
on these subjects, too many to name here, but the forlowing list suggests a number of works which are conparatively simple and which are not too elaborate. These or substitutes can probably be procured from the nearest library.

\section{ART.}

Reinach, Solomon. Apollo. An illustrated manual of the History of Art throughout the Ages. New York, 1910, Chas. Scribner's Sons, $\$ 1.50$.

Ars Una: Species Mille. A new Universal and International Series of Art Manuals. These are written by various authorities on the art of various countries and are excellent. Chas. Scribner's Sons.

Masters in Art. A series of monographs published from 1900 to 1909 by Bates and Guild Company, Boston, Mass. Single issues and complete volumes probably can be procured. These are most interesting, and ten plates illustrate each artist-subject.

Artist-Biographies. A series of thirty biographies published in the late 70 's by James $R$. Osgood and Company, Boston. These are not illustrated but are good.

Masterpieces in Colour. Edited by T. Leman Hare. New York, F. A. Stokes Co., London, T. C. and E. C. Jack. These monographs are very good.

The Painter's Series. New York, F. A. Stokes Co. Each gives sixty miniature reproductions of the artist-subject's works. 25 cents each.

Bell's Miniature Series of Painters. London, Geo. Bell \& Sons.

\section{ENGLISH LITERATURE.}

Brooke, Stopford. A Primer of English Literature. New York, D. Appleton and Company. This is very short, but is an excellent introduction to the subject, or may be used as an outline.

Beers, Henry A. An Outline Sketch of English Literature. 
New York, 1886, Chatauqua Press. This is more interesting than the above as it is not so very brief.

Other excellent books have been written by Newcomer, Halleck and Brooke, and are used in schools.

\section{AMERICAN LITERATURE.}

Nichol, John. American Literature. A Historical Sketch, 1620-1880. Edinburgh, 1882, Allam and Charles Black.

Simons, Sarah E. Syllabus of American Literature. This is an excellent guide for suggested readings. Unfortunately no publisher is noted and I do not know how it may be procured.

Newcomer, Halleck and Brooke have also written textbooks on American Literature.

If any of the above seem to be too ambitious an undertaking, a substitute may be found in one of the following courses, which were very kindly given me by a teacher of literature. After going through one of them the patient may desire to extend the reading and may he persuaded to take up either the English or American literature. It adds interest if the nurse can interpolate bits of collateral reading either about the author or his subject. l'ictures may be used to assist in fixing subjects in the associative menory. Those series of prints known as Perry Pictures. Brown Pictures, or ('osmos Pictures can be procured very eheaply. An atlas may make a hook of travel. or even fiction. more interesting, for example Kate Douglas Wiggin's Cathedral Courtshipe or the Williamson's Motor Matid, or the chanffour and the Chaperone. will be more interesting if the routes tratrelled are shown graphically before us. 


\section{BRIEF LITERATURE COURSES.}

I. Short Story Course.

The Lady or the Tiger?-Stockton.

The Ian Without a Country.-Hale.

Marjorie Daw.-Aldrich.

The Gold Bug.-Poe.

Twice Told Tales.

Great Stone Face, etc.-Hawthorne.

Sketch Book.-Irving.

II. Dialect stories dealing with provincial life in different sections of our country.

1. Negro.

Meh Lady, or Marse Chan.-Thos. Nelson I'age.

Uncle Remus Tales.-Joel Chandler Harris.

2. Creole.

Old Creole Days.-Geo. W. Calle.

3. Indiana.

The Hoosier Schoolmaster.-Edward Egglesion.

4. Dutch Life.

Knickerbocker's History of New York-Irving.

5. Middle West.

Hamlin Garland's Stories.

6. Extreme West.

Bret Harte's stories.

The Luck of Roaring Camp.

Tennessee's Partner.

Fitzgerald's stories.

7. New England.

New England Nun.-Sara Orne Jewett.

The Revolt of Mother-Mary E. Wilkins.

8. The Brittany French.

The Unknown Quantity.-H. VanDylie.

9. Western Canada.

Ralph Connor's Stories.

10. Prince Edward Island.

Anne of Green Gables.-Mont gomery.

11. Mountaineers.-Fox. 
III. Children's Stories.

Just So Stories.-Kipling.

Tanglewood Tales.-Hawthorne.

Uncle Remus.-Joel Chandler Harris.

Nonsense Books.-Edward Lear.

Also books by Sara Cone Bryant. Beatrix Potter and Lewis Carroll.

IV. The Ghost Stories of different Nations.

Japan, Germany, etc. (This course would be suitable for very few mental cases whose mental make-up must be well known before it is suggested.)

V. The Fairy Tales of Various Literatures.

VI. Indian Legends and Folk Lore.

Hiawatha.-Longfellow.

Ramona.-Helen Hunt Jackson.

VII. Present-day fiction that is worth while.

VanDyke, Quiller-Couch, Arnold Bennett, F. H. Burnett, K. D. Wiggin, Kipling, Waller, Porter, Bosher, etc.

VIII. The Evolution of the Novel.

Defoe, Swift, Richardson, Fielding, Austen, Sterenson, Dickens, Thackeray, Howells, James, etc. (Heavy course.)

Nineteenth Century Novelists of Englant.

IX. American Humorists.

Lowell-Bigelow Papers.

Holmes-Autocrat of the Breakfast Tahle.

Mark Twain-Innocents Abroatl, etc.

Artemus Ward.

Bill Nye.

X. Literature reflecting historical epochs.

Scott, Muhlbach, Bulwer-Lytton, Dixon, Churchill, F. Hopkinson Smith, Charles F. Major. 


\section{PHYSICAL EXERCISES.}

Besides th 2 passive movements, massage, ete., that the nurse learns in her general course, it is necessary for her to liave a knowledge of calisthenies. It is well known that unless a part is exercised the motor nerves supplying that part will atrophy, and for this reason active exercises are frequently ordered for mental cases. Sometimes the patient goes to a grmnasimm for the exercises. but this is frequently impossible and it is well if the nurse knows ealisthenic exercises which she can teach the patient and which can be carried out in the lome. Snall hand-books giving very good directions can be procured from athletic goods stores, usually at a cost of ten cents. Larger books can also be bought. one being My System, 15 Minutes' Work a Day for Iealth s Sake, by J. P. Müller (New York, G. E. Stechert \& ('o.); or How to get Strong and IIow to Stay So, by William Blaikie (Tew York. 1598, Inirper (f Brothers). The nurse can watch the newspapers and periodicals and. with the articles on exercising which so often appear in them, make a very good mannal of her ewn. In especially good article was by $1 \mathrm{~m}$. J. Cromie. ${ }^{1}$ which appeared in the Oullook. The article is well worth reading. lnt for the benefit of these whe

1 ('romie, W'm. J. Eight Minutes' Common Sense Expreist' for the Nervous Woman. The Outlook, July 25, 1914, p. Tist. 
camnot procure it the fullowing directions are copied by permission.

First Exercise. Secure a Turkish towel of sufficient length to enable you to take a wille reach. The towels used in the illustrations are made of two ordinary Turkish towels sewed together. Take a wille grasp as in position A. Pull strongly upon the towel, up on toes, raising the arms above the head, as in B. Lower to A. This exercise develops the calves of the legs, the arms, the back, and explands the chest. (See Fig 3.)

second Exercise. From position A pull upon towel and bend knees as in $B$. This movement reduces fat on the hips and is a good balance exercise. Do not lean forward or backward, but lieep erect as in figures. (See Fig. 4.)

Third Erercise. From a pull on towel (lower trunk forward, as in B), bend forward to a stoop-stand position. This corrects round shoulders and flat chest, and stretches all the muscles of the upper body. The hips, shoulders, head, and arms should be in a straight line. Practice in front of a mirror. (See Fig. 5.)

Fourth Exercise. This exercise is performed in four counts or parts. From ordinary standing position, as in first exer(ise, position $A$, count 1 ; charge, as in $A$, right legr forward. On count 2 pull on towel, twisting boty to the right, as in 13. On counl : return to gosition $A$, and on count 4 return to siarting position. The same, left leg forwarl, twist to left. This exercise gives strong waist museles and reduces fat in this region. 13oth heels should be kept solidly on the floor, and rear leg straight. (See Fig. 6.)

Fifth Ererrise. On count 1, from slarting position, raise the arms alove the head, chatring to the right side, as in $A$. On count 2, licep the weight of the hody upon the right leg. lending to the right as in 13 . On comnt is return to position A. On count 4 return to starting position. Perform the same to the left side, benting to the left. Bend only the "harging leg. This "xercise is sometimes called the "liver squerer," and it stretches every muscle in the boty. (See Fig. 7.) 


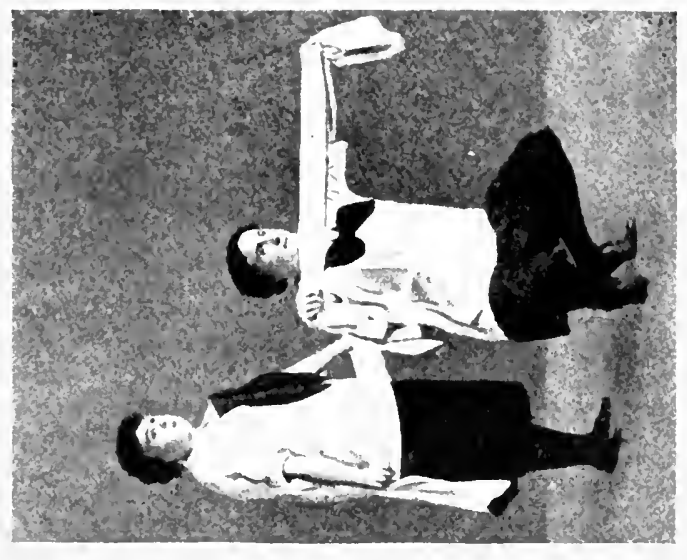

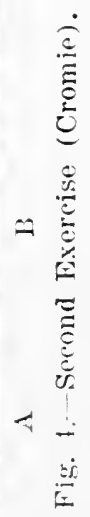

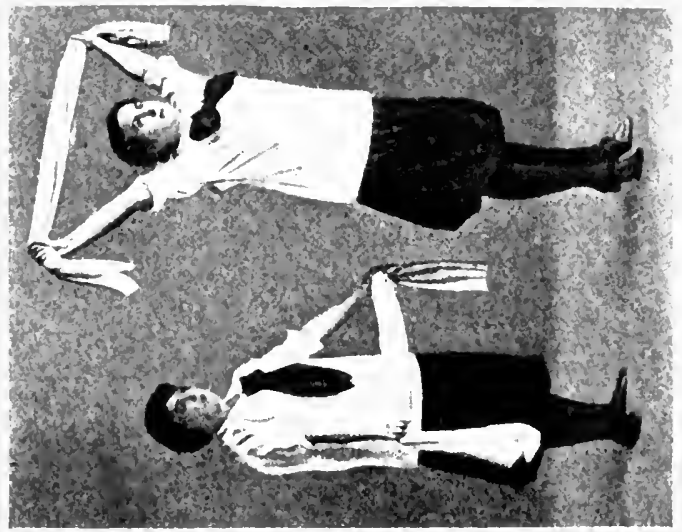

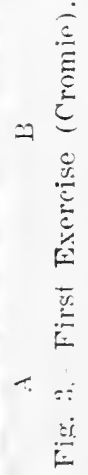




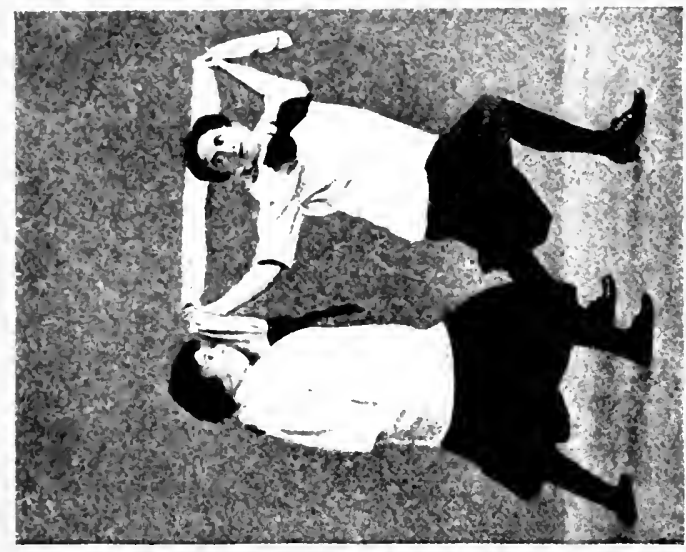

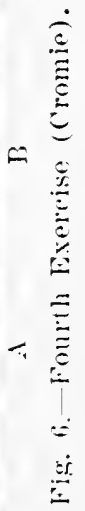

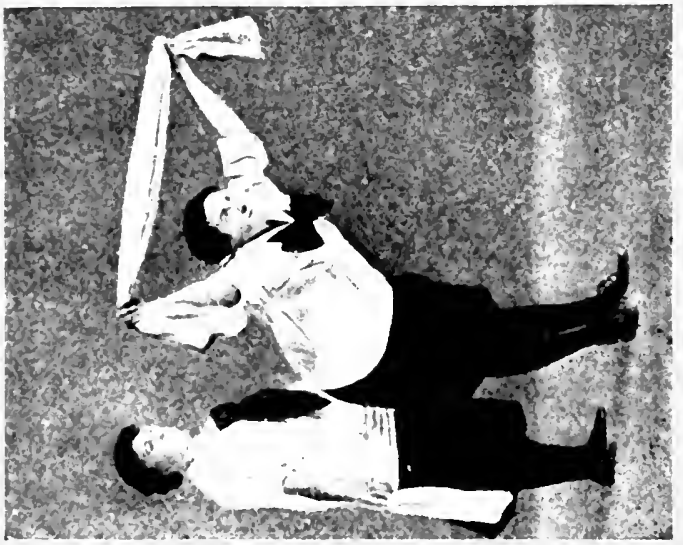

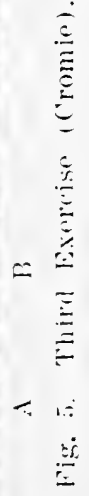



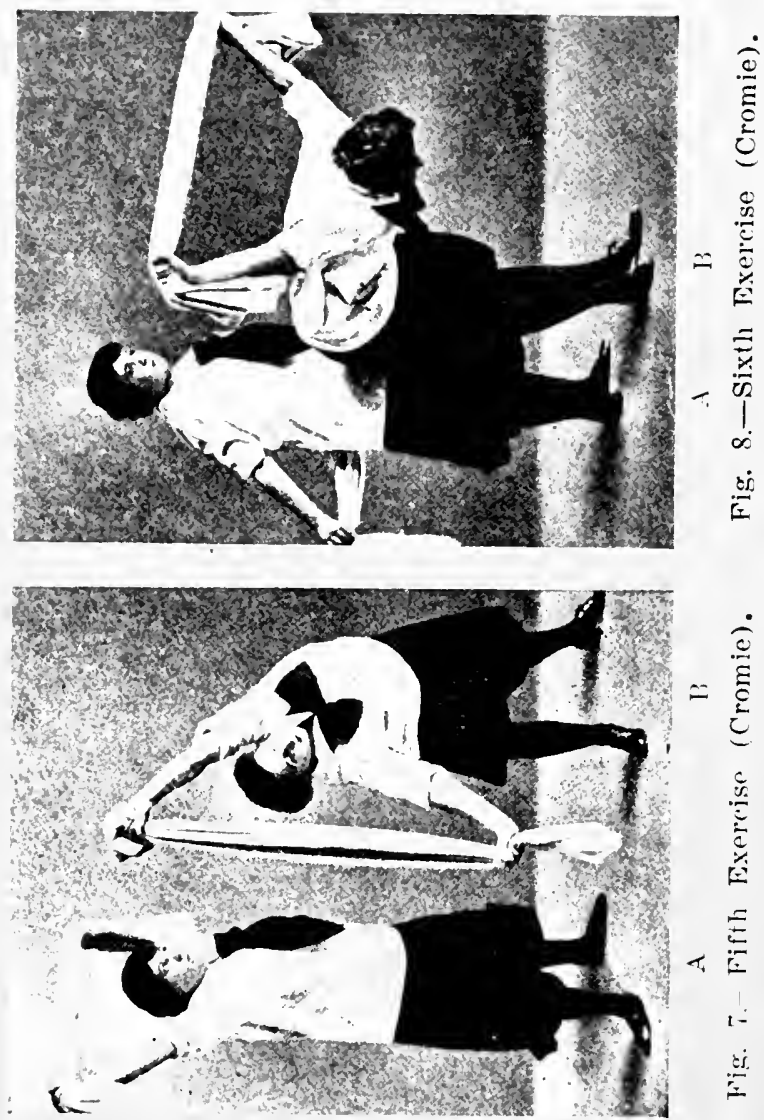

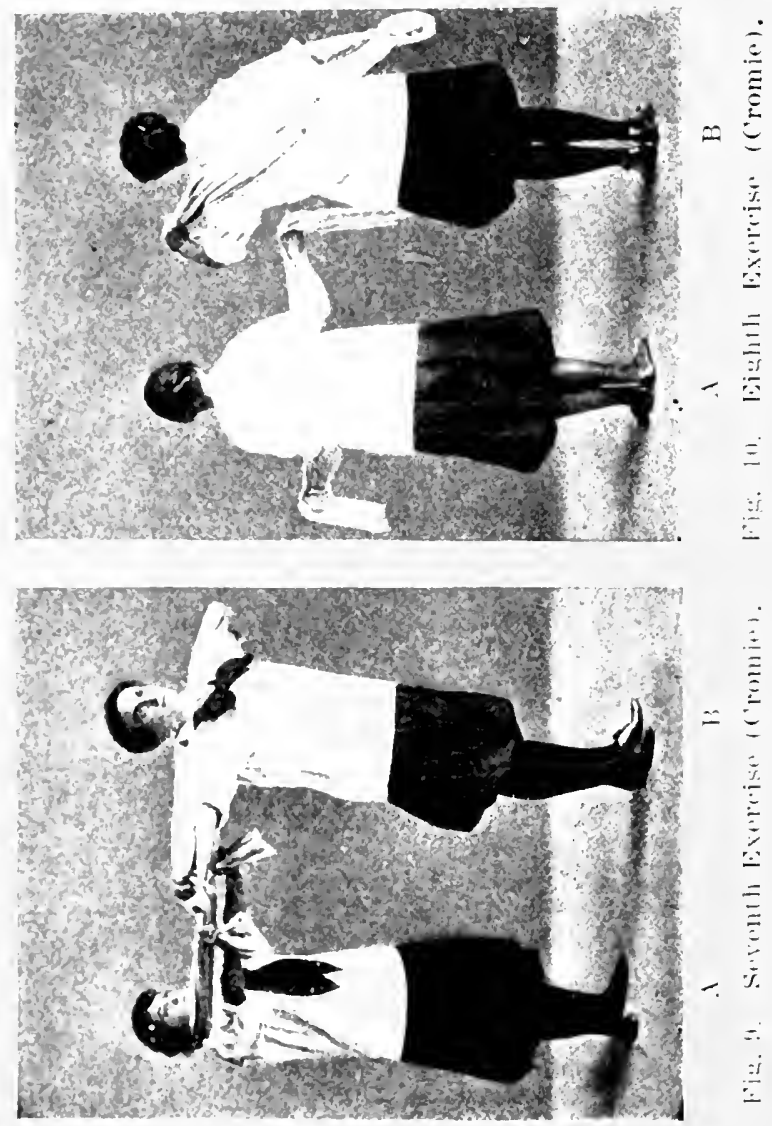
sixth Exercise. Grasp the towel in the rear, as A. Pull on the towel, bend forward, bringing arms up, as in $B$. When $A$ is again reached, bencl backward. This is a good exercise for the abdomen and back. (See Fig. 8.)

Seventh Exercise. Finish the exercising with a deepbreathing movement. Towel back of neck, arms together in front, as in A. Arms back as in B, taking a deep breath while so doing, breathing out from $B$ to $A$ position. (See Fig. 9.)

Eighth Exercise.-Take a sponge or towel bath by saturating either article in a basin of cool water. Wring the water out and quickly wash all parts of the body. Follow this witl a dry rub. Saw a dry, coarse towel across the back, as in A, Exercise 8; then up and across the back, first one side, then the other, as in $B$. Rub all parts of the body until it is in a glow. You are then ready for anything the day may demand of you. (See Fig. 10.)

Simple exercises without apparatus are best, and aro more raluable if they can be done to music, which is usually possible in this day of mechanical music. Rhythmie dancing would appear to have great ralue, but seems to be a little too diffieult for any but a professional teacher.

Sometimes the simple elothing which is necessary for freedom of movement makes a self-conseions patient embarrassed, so that this must be overcome. There womld appear to he eneat possibilities in this rhythuic dancing.

The nurse shomld have some knowledge of ordinary sorebety dalloeses and especially should she be able to play temis and golf in order that she may act as alversary. lu all playgromed anues competition is desirable as it brings out the hest that is in the children, and it wonld 
seen that many mental patients might be helped in this same way. A knowledge of other ontdoor sports may also le desirable, for in nursing. as in everything else, the more one knows the greater the resoures within one. Participation is important even in the ordinary simple exercises, and the nurse should comnt alond in order that the patient may learn to do the exereises rhythmically. 


\section{CARD GAMES.}

"Those inventions of the Devil," as the English Puritans called cards, lave probably been the instruments of quite as much good as harm in the world. Card games are great helps in mental training, and the nurse should have a number at her command with which to divert her patient. There are so many of these ganues that it is not an easy matter to select them, but there are a few which seem to be especially important for the nurse to know. It is well to know a few simple tricks also, as, like eatches and puzzles, they may serve to arrest the attention of the patient and make possible further occupation of this sort.

The listory of playing-eards is quite interesting. They are generally believed to have come from Isia, and in a Chinese dictionary. published in 1678 , it is said that they were invented in 1120. There is a tratdition that they have existed in India from what the otd colored woman called times immoral, and that they were invented by the Brahmans. Very ancient round cards are preserved in some musemms. Their invention has also leen aseribed to the Figrptians and to the Arabs. Tust when they were introduced into Europe is doulteful, Thut in the accomnt hooks of .Tohamul. Duchess of Brabant, there is an entry under date of May 14, 1:36! als follows: "Civen to Monsieme and Iartan four peters. 1 wo florins. value eight and al halt 
moutons, wherewith to buy a pack of cards." It is believed that cards eame into general use in Europe about the end of the 1tth century. Whenes they cance is a matter of conjecture. Py some it is belierod they came to Italy from Aralia, by others to Spain from Ifrica with the Moors. The Crusaders may have introduced them.

Cards have been mentioned in laws, edicts and sermons. In 1:397 the working people of l'aris were forbidden to play at temis. bowls, dice, cards, or ninepins on working days. In 1+2:3 St. Bemandino of Siena preached a celelrated sermon against cards at Bologna.

The use of cards for other purposes than gaming dates from 1509, when a Francisom friar published an exposition on logic in the form of a pack of cards. Grammar, geography and heraldry soon followed, and to these was applied the name "scientiall eards." This hrancle las been much developed in recent years, and rhildren are taught a knowledge of anthors. birds animals, ete., ly means of eald games.

There have been several histories of playing-eards written. but most of the ahove is abstracterl from the Eucrelopedia Srittanica. in which there is a very interesting article containing many other farts and a biblingraphly. There is an exeenlent anllection of playing-ards in Jemorial Ilall, Fairmomnt Park, Philatdelphia, which is wortle a visit hy one interested.

A Simple Card Trick. Take niur atrde and la! them down singly, farene un there piles. tolling the pationt to select one withont maming it. 'Then ask him in 
which pile it is. Gather the piles without mixing, being careful to remember in what position relative to the other two that the named pile lies. Again lay them out in three piles, again ask the patient to point to the pile in which the selected eard is, and if the first numed pile has been laid out last, the named card will be the top card, if laid ont second it will be the middle card. an if laid ont first it will be the bottom eard. The selected card may be said to be found perpendienlarly by the first layout and found horizontally by the second. The trick may be made to appear more diffieult by taking a larger number of cards, always the square of the number of piles.

There are a great many other simple eard tricks which may prove of value, but it is the games which are more important.

In order not to extend this book too greatly the murse is adrised to buy a book on card games, such as that published ly the Tnited States Playing Card Company, of Cincinnati, entitled The Official Rules of Card Games, and which may be bought for twenty-five cents. This is not so complete as Hoyle. published by I)ick and Fitzgerald for 50 cents, but is adequate and is rerised realry,

There are many forms of Patience or Solitaire. wrer one bundred and twenty-five having been published. and it is difficult to say whirh of these is the hest. Some of them differ very slightly. I believe that the following ane the best to learn at first heralluse they may he said to be graded. Baker's Dazen heing guite cans. 
Rainbow more difficult, and Klondike or Canfield still more difficult. Special books on solitaire may be purchased. but the I'. S. Card Games gives all of the above and more.

It is generally eonceded that Cribbage is the best two-handed card game. It has the advantage of being simple, of not requiring any special skill to play it. The method of scoring is easily learned. Cribbage hoards on which the scoring is done can be easily made. but they can be bought quite cheaply; and the nurse is advised to provide herself with one. A very attractive little folding one is made ly. Daniel Jow \& Co. of Salem, Mass., and costs fifty cents.

Euchre, Draw Poker, ean he played by two or more and should he learned. I knowledge of Whist, Bridge. Anction and Five ITundred may prove convenient.

Fan Tan, a form of solitaire for from three to ten persons is a splendid game for ward use.

Dominoes.-Dominoes is not generally considered a ward game. lut as the pack of aurl dominos made hy the I. S. Playing Card (ompany is the most conrenient form for the nurse it may pruperly be placed in this chapter. The munsual form may serve to at onde exeite the interest of the patient. Directions for playing several games with dominoes aecompany each pack. These come in two sizes. one of the ordinary playing"ard size and the other smaller, $133 \times 23$ inches. The latter is recommended. 


\section{STRING WORK.}

The material for this may be found in every household. If the family is improvident and has no string box. the nurse has only to ask the cook for the string from the parcels the groeer's boy brings, or the female relatives for that from packages from the department store, and she will have an ample supply. If the patient is a single gentleman without cook or female relatives almost any store will be glad to give a ball of string for a consideration. The eommonness of this material makes knowledge of how to use it especially valuable.

String is a general term applied to thin eord or stout thread and is derived from the Latin stringere, which means to draw tight. The Old English form is streng, the Danish streng, the German strang.

Our savage forefathers, not having grocers, or department stores, were obliged to use tendons or strips of hide from animals, vines, twigs, etc., for the purposes which we ordinarily use string.

Commercially we have twines, lines, eord, and rope. Twines and lines are forms of string. Cord is between string and rope in thickness (romng rope, as a friend of mine ealls it), and the name is derived from the Latin chorda, French corde, meaning the string of a musiral instrument. Rope inchdes all varicties of cordage having a cireumference of an inch or more. 
Sitring is usmally made from rotton or linen, while rope is made from cottom, hemp (which makes the lest ), and jute which is used ehielly ats a diluent for the more expensive herup. Jute cord in a variety of eolors is nsed in kindergarten work and may be purchased from stores supplying these materials. liope is made from yom, which is twisted filme, twisted so that it will hold together. One or more yims in three groups are twisted in the opposite direction to form rope.

\section{STRING FIGURES.}

Probiluly all of us have played the game known as ('at's c radle, lut muless we have heen so fortumate as to read a most interesting book by Mrs. ('aroline Furness davae on String Figmes we have not realized low murh interest is attached to it mor how mamy of these string figures there are. The game is knowu all orer the world, and the same figme may be fommd in widely different localities muder different manues. lior example, the figme kmown as "The Leashime of lat

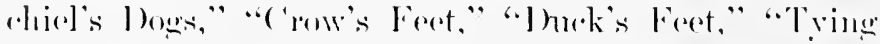

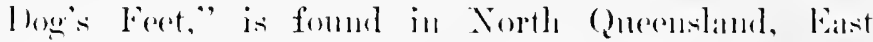
Ifrira, Sorth Amerieas, and the british Isles. It rall also be male in a dozen different ways. It is poubable that the worel ('at's is a corruption of atrele and that

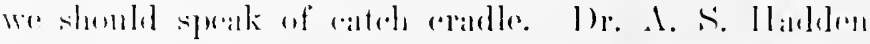

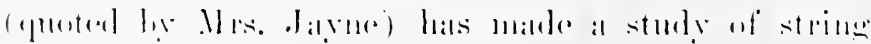

1 String Figures. A Study of Cat's-('radle in Many Lands

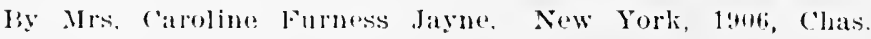
Scribner's suns, $\$ 5.00$. 
figures from an ethological standpoint and has divided them into two types, which he ealls the Asiatic and the Oceanic. The string figures of the North American Indians belong to the latter type. The chief difference is in the opening. In the Oceanic type the strings do not pass over the back of the hand, but back of thumb and little finger and across the palm. This is called opening A. In the Asiatic type the string passes around the hand as in the real cat's cradle, and is called opening $B$.

The descriptions which follow are copied from Mrs. Jayne's book by permission of the publisher's.

String figures are made with a piece of string abont six feet long, the ends of which must be tied together to form a single loop ahout three feet long. In some races a thong of skin is used; in the islands of the Pacific a cord male of cocoamt fibre, or of humam hair fincly plaited. serves as a string. I woven cord whichl does not kink as easily as a twisted eord will prowe most satisfactory; unfortunately, it camot be splieed. the ends therefore must be knotted in a small sflualre knot or laid together and bound round with thread.

1ll string games begin with an opening, the olject of which is to get the original loop so arringed on the hauds that a mumber of seeondary loops shall eross from the fingers of one hand to the finger's of the other. when the hands are held in what is alled their nsulal pmition. namely, with the palms facing eateh other, and the fingers directed upward. 


\section{REAL CAT'S CRADLE.}

As Dr. Iraddon has pointed ont, the familiar game of cat's eradle probably had its origin in Asia, whenee it was introduced into Europe; it has also spread to some extent anong the Asiatic islands. It is well known in China, Korea, Japan, the Philippines and Borneo: and it may be known in . Java, ('elebes and Australia. It is apparently known in Mieronesia, Polynesia, and to the Anerinds. In Enrope it is recorded from Austria. (iermany, the Netherlands, Demmark, Sweden, Switzerland, France, and England. From France it has spread into Torthern Ifrica, for I)r. IV. II. Furness found several little Arab girls in the tapestry school in Algiers who played it exactly as we do; they leamed it in a French school. Of conrse, it is probably known in all farts of the world which have felt the influence of European (*ulture.

IVe have not lreen alle to find any reeord of the time or mamer of its introduction into England, lout this untst have happened within eomparatively recent years. ats there ale no refereneess to it in the older literature. Moreover, no satisfaretory explanation of the name

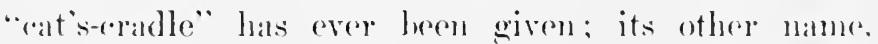

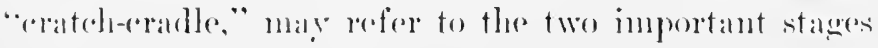
of the ganne: the "manger" (a crateh) and the "oratle."

In Sonthern china cat's cradle is known ats Kang sok woll rope: in Swatow the name means ".stawne

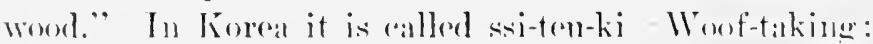
and in Jilnan. Aral ito tori- lloof pattern String-tak- 
ing. In Germany it has rarions names: $A$ bheben=Taking off ; Faden-abheben='Taking off strings ; Fadenspiel=String game; Hexenspiel = Witeh's game, and Auf-und Abnehmen=Picking-up and taking-off. In Holland it is known as Afpakken: Dradenspel=Taking-off: String game; In France and Algeria as la scie.

Two persons and one loop of string are required for the game of "Real Cat's-Cradle," which is played by the persons alternately taking the string off each other's hands to produce eight definite figures, which have been given distinctive names, as follows: 1 , Cradle; 2 , Soldier's Bed; 3, Candles; 4, Manger; 5, Diamonds; 6, Cat's Ere: 7. Fish; 8, Clock. For convenience in describing the game the players will be called " $A$ " and "B." The terms "near," "far," "right," and "left" describe the position of the strings as seen by the person from whose hands the figure is being taken.

\section{(I) Cradle.}

Synonym: Sang-tou-ton-ki=cover for a hearse (Korea); le bercean (France); Wasser (Brabant).

First: "I" takes the string and passes the four fingers of each hand throngh the untwisted loop, and separates the hands; then with the thumb and index of the right hand he turns the left near string away from him across the left palm, and then toward him across the back of the left hand, bringing the string to the right between the left thmmb and index. In the same manner, he turns the right near string once around the 
right hand. There are now two strings across the back of each hand and a single string across each palm.

Second: Opening $A$ (picking up the palmar string with the middle finger). There is now a loop on each middle finger and two strings across the back of each liand; the "Cradle" being formed by a straight near string, a straight far string. and the crossed strings of the middle finger loops (Fiz. 11).

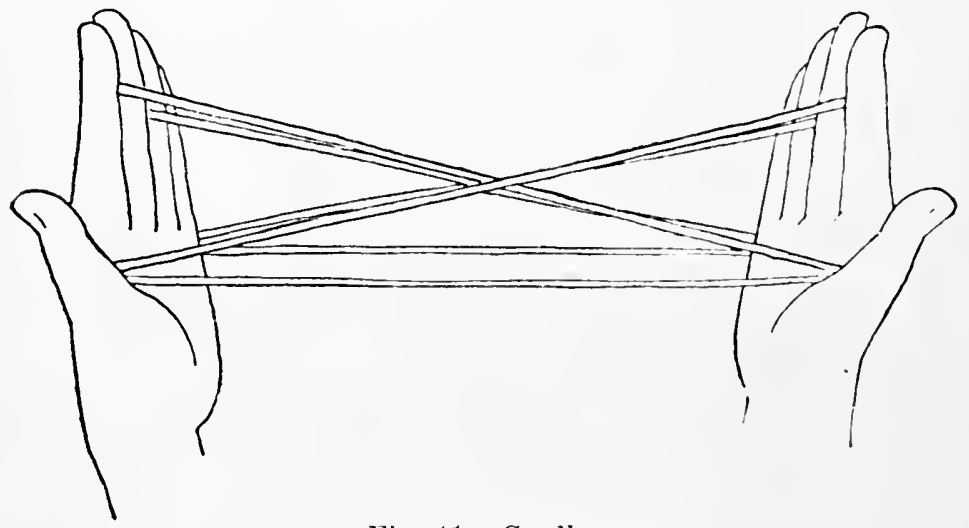

Fig. 11.- Crarle.

\section{(2) Soldier's Bed.}

Synonyms: Pa-tok-hpan- Chess board (Korea); nekomata = momtain cat into which a domestic cat is suppesen to transform itself ( Japan) : die Sehere (Bra-

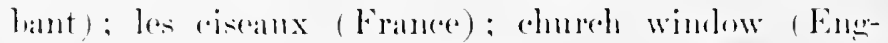
land): fish poud (. Americat).

"I," puts his left thmmb away from ".l" under the right near middle finger string and his left index away 
from " $\mathrm{A}$ " under the left near middle string, and then, by bringing the thumb and index together, picks up between their tips the two near middle finger strings just

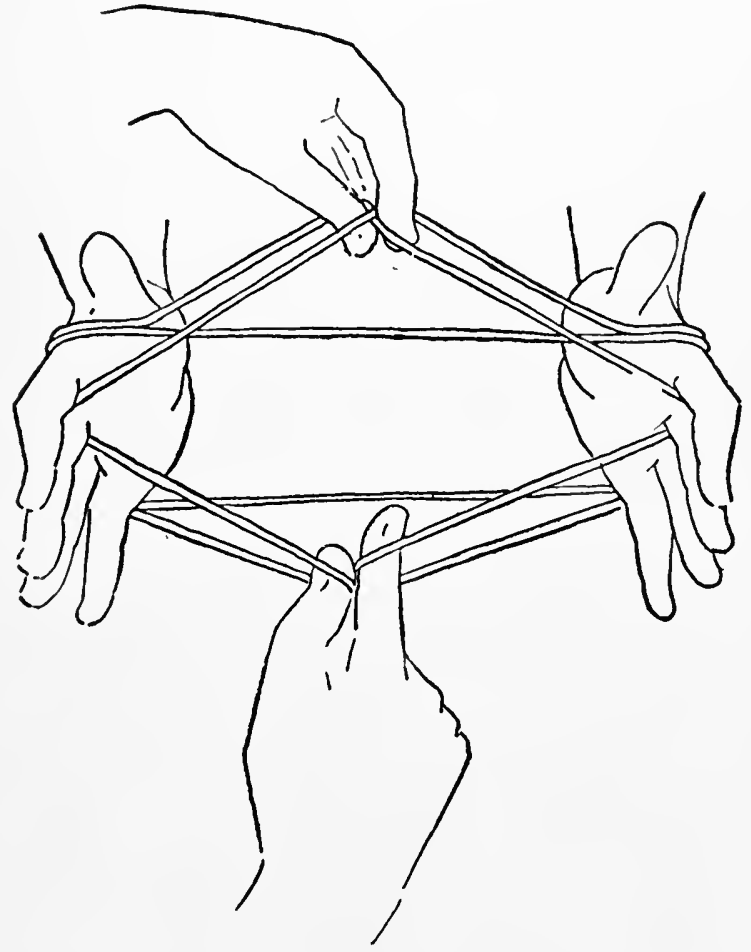

Fig. 12.-Soldier's Bed.

where they cross at the near side of the fignre. In the same mamer he picks up the two far midlde finger strings, by putting the right thumb toward ".l" under 
the right far middle finger string. and the right index toward " 1 " under the left middle tinger string, then bringing the thumb and index together to hold the two

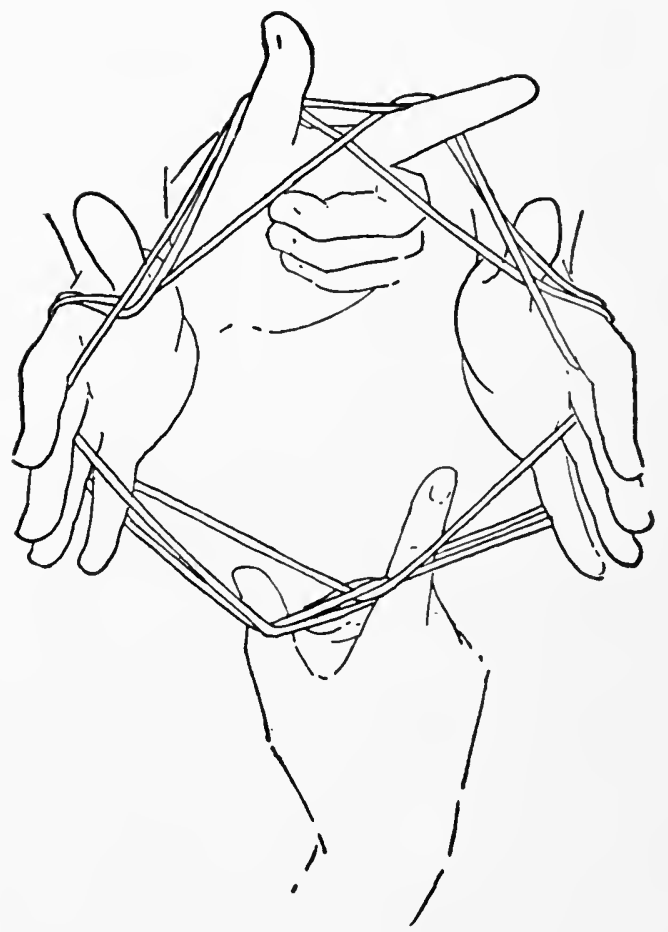

Fig. 1\%.

strings where they eross at the far side of the figure. Now separating his hands, drawing the right hand awa from "I" and the left hand toward "A" (Fig. 12), he alries the thmmh and index of eareh hand still 
holding the strings, around the corresponding side string of the figure and up into the eentre of the figure (Fig. 1:3); then, by drawing his hands apart and separing the index fingers widely from the thumbs, he removes the figure from " $A$ "s" hands and extends the Soldier's Bed (Fig. 14). There is a loop on each thumb, a loop on each index, and a string passing across the bateks of the thumb and index of each hand. The fignre

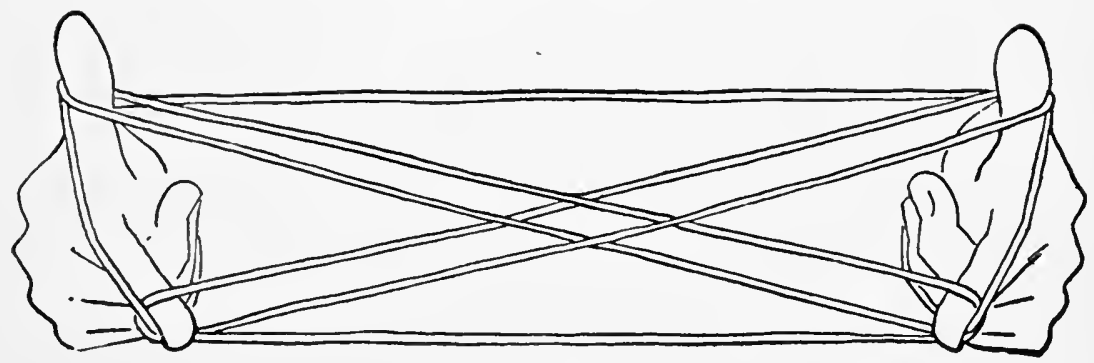

Fig. 14.

is formed of the fomr finger lonps crossing in the mistdle. a straight near string and a straight fin string.

\section{(3) Candles.}

Symonỵms: Tjye-ka-rak - chopsticks (Korea): Kioto a musical instrmment, or geta no hat = the two pieces

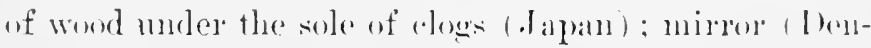
mark): les cluandelles (France): die (ieige (brabant).

" 1 " inserts his left index from above into the loft thmub loop. near the centre of the figme, and his loft thmul, from allwe into the right thmul, lowp. and thene 
bringing the thuml, and index together. picks up between their tips the near thumb strings just where they aross. In like manner, by inserting the right thumb, from allove into the right index loop and the right in-

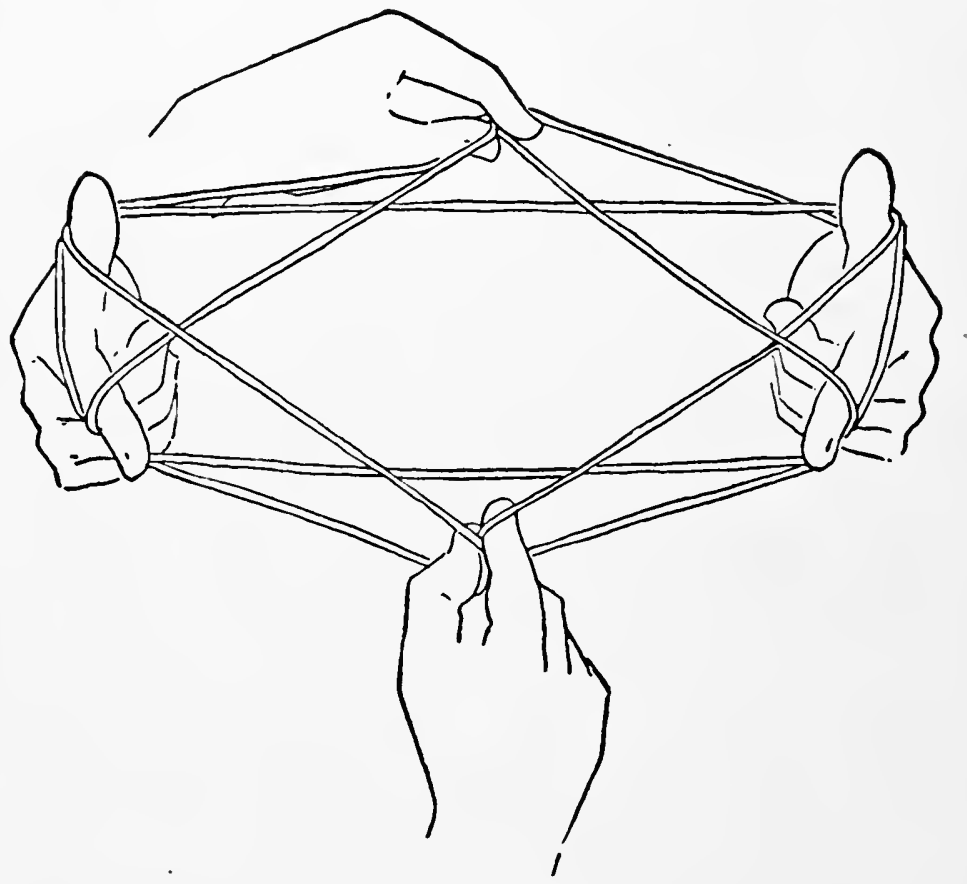

Fir. 15-canclles, !.

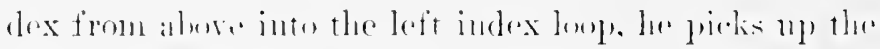
two fall index strings where they eross. He then sep alrates the hands-drawing the right hatud awaly from "I," over. and palst. the fall straight string, and the left 
lound toward "P" over, and past, the near straight string ( Fin. 15); and finally puts the thumb and index of each hand (still holding the strings) mder the corresponding side string and from below into the centre of the figure, when, by drawing the hands apart and separating the index fingers widely from the thumbs, he takes the figure from "B's" hands (Fig. 16). There

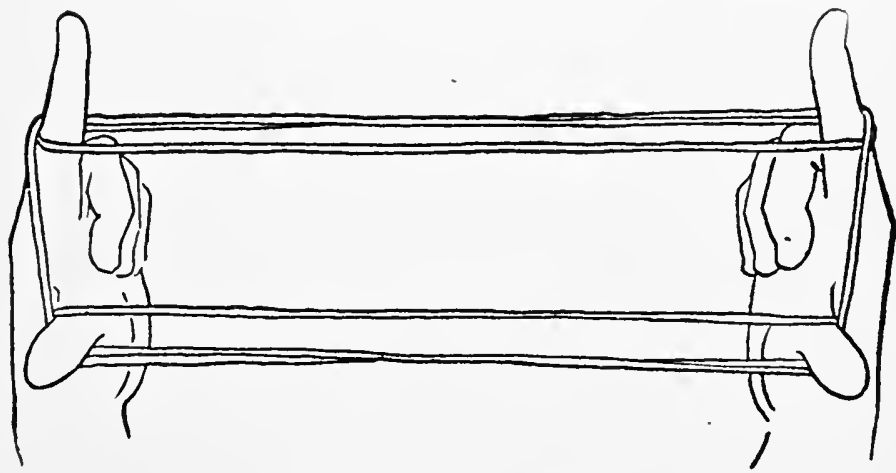

Fig. 16.-Candles, II.

is a loop on each thumb, a loop on each index, ant a string passing across the backs of the thumb and index of earlh hand: the "Candles" leeing formed by a straight single fatr thumb string. a stratight single neatr index string. and straight double far index and near thmul, strings.

\section{(4) Manger.}

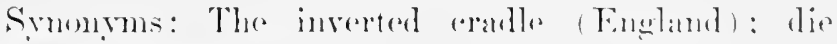
Wiege (Brahint). 
" $B$ " turns his left hand with the palm facing upwarl. and takes up in the bend of the little finger the near" index string, and draws it over the strings toward " $\Lambda$;" then turning his right hand with the palm up, he takes

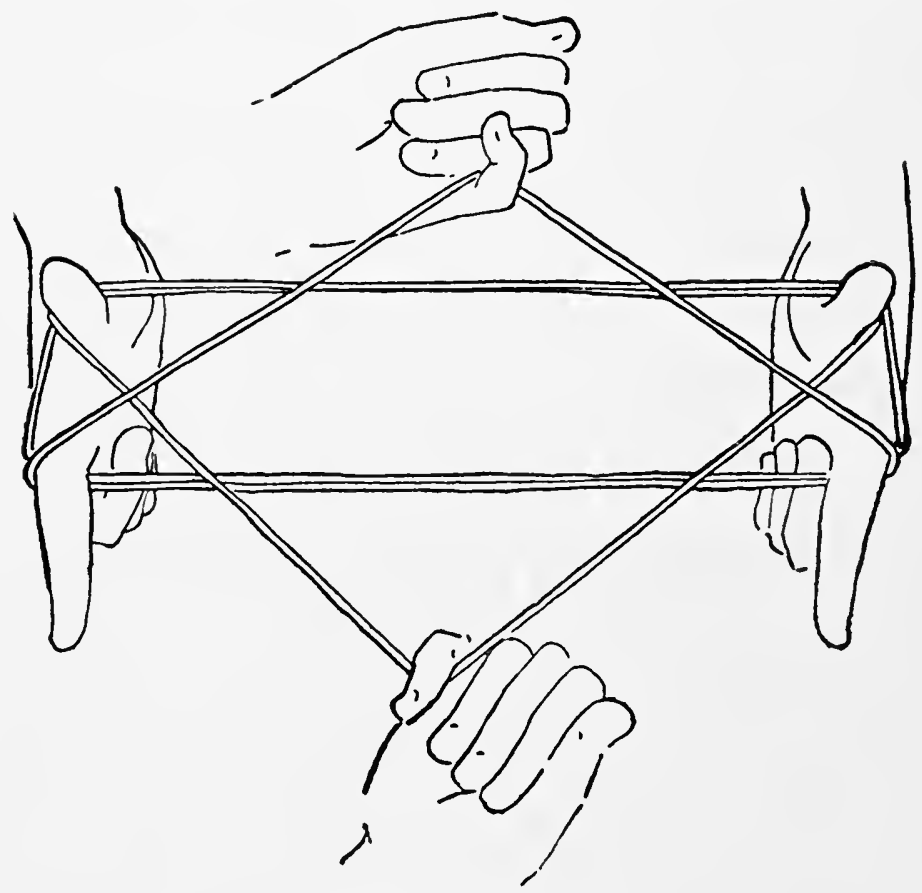

Fig. 17.-Wanger, I.

up in the bend of the right little finger the far thumb string and draws it over the other strings away from "A" (Fig. 17). Closing the little fingers on the pallus. he passes the left thumb and index from the near side 
under the two near thumb strings and up on the far side of them, and at the same time passes the right thumb and index from the far side under the two far index strings and up on the near side of them (Fig.

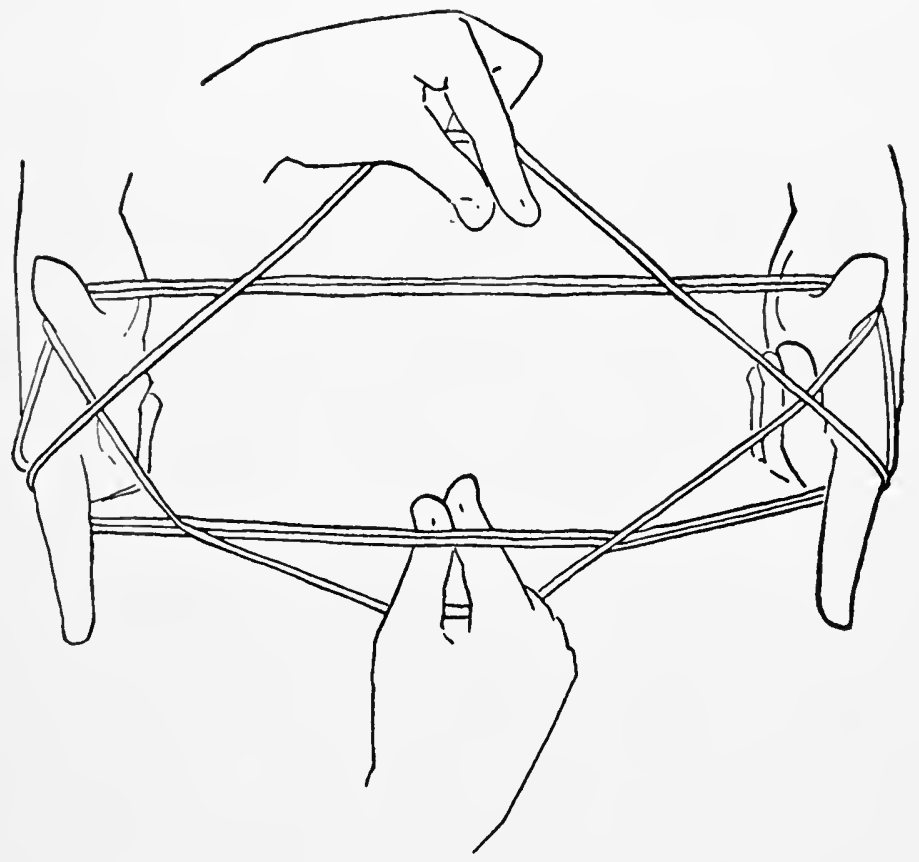

Fig. 18.-Manger, II.

1-). Them, drawing the hands apart, and sepanating the index fingers widely from the thumbs, he takes the figure froun "As" hands (Fig. 19). The now has two string's passing aromss the backs of the thmmb and index 


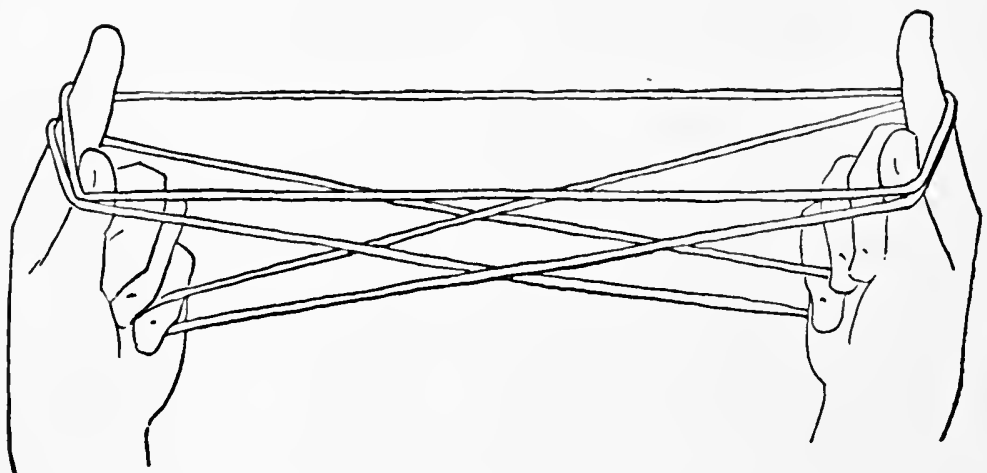

Fin. 19.-The Manger, III.

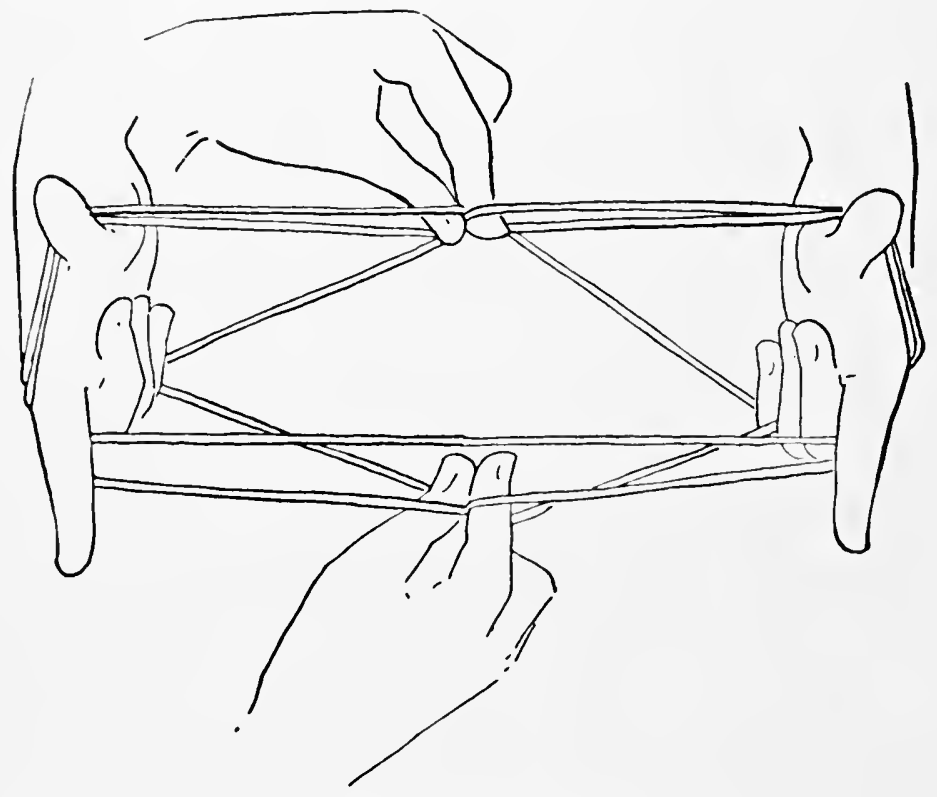

Fig. 2n,- Diamonds, I. 
of each hand and a loop held to the palm by each little finger. The form of the "Manger" is the same as that of the "Cradle" only inverted.

\section{(5) Diamonds.}

Synonyms: Soldier's Bed again (England); les earreanx (France).

" $A$ " now takes the "Manger" from "IS's" hands in the same way as " $B$ " took the "Cradle" from his hamels. but the thumb and index of each hand (holding between

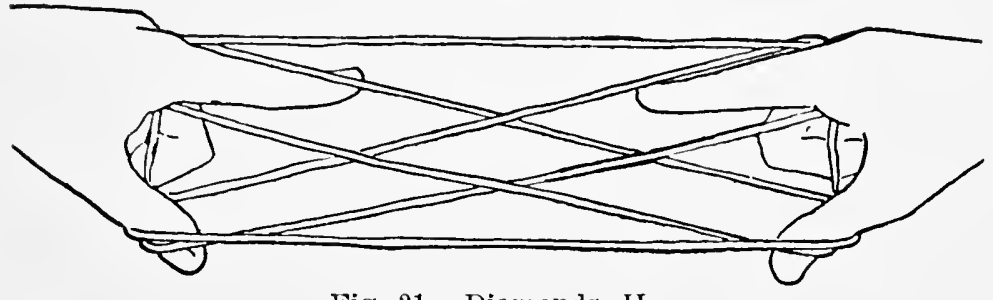

Fig. 21.-Diamonds, II.

their tips the two erossed strings) are bronglit up around the corresponding side string and down into the centre of the figure (Fig. 20 ) ; them, when the hands are drawn apart and the thumbs and index fingers widely sip arated, he forms a figme exantly like the "Soldier"s Ped." lont it is leeld with the fingers pointing downward (Fig. :21).

\section{(6) Cat's Eye.}

Srononyms: Sol-nom-kil = Cow's Eyco-ball (Komeil): umano me-Ilorse-eye (Jipan); diamonds (England). 
"I," takes the figure from "A's" hands in the same way as " $A$ " took the "Soldier"s Bed" from " $B$ " to form the "Candles" (Fig. 22); but, althongh he has a loop on each thumb, a loop on each index, and a string pass-

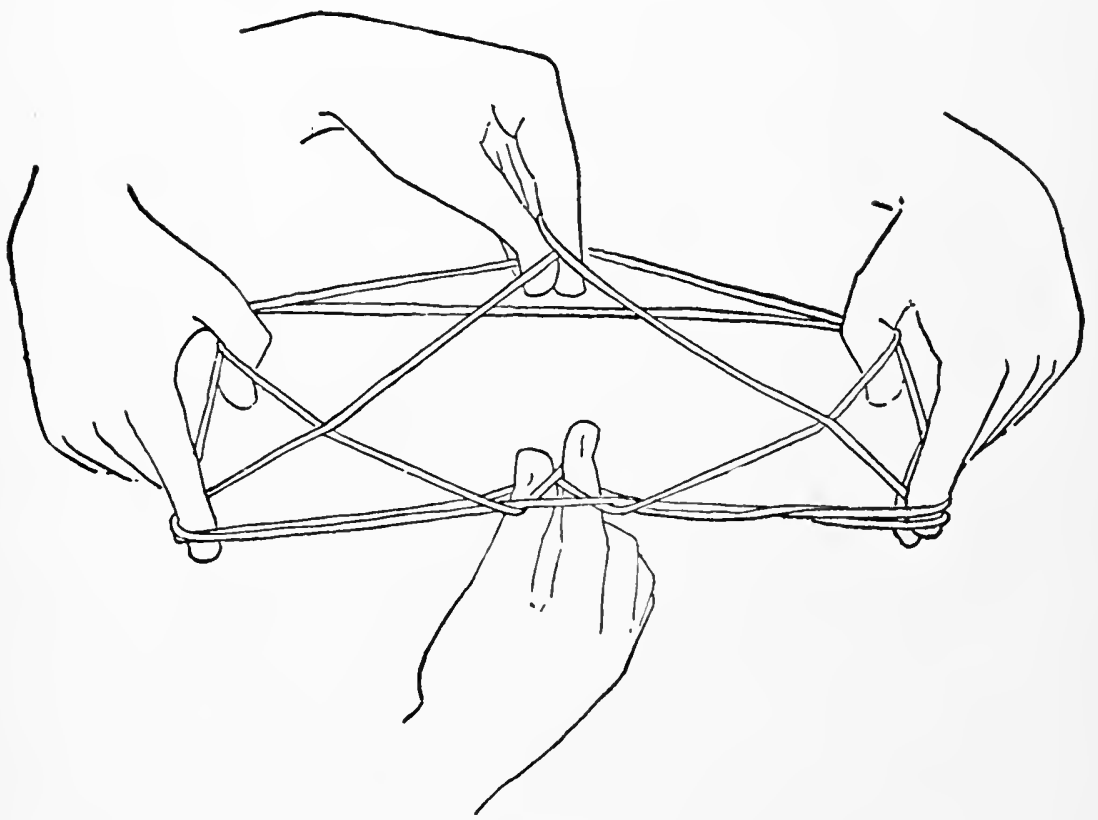

Fig. 20.-Cat's Eye.

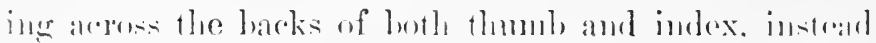

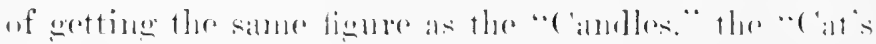

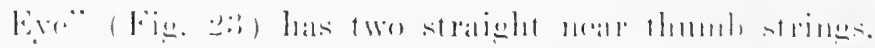
two straight forl index stringes and aresced far hommb string forming a central lozenge and four triangles, 


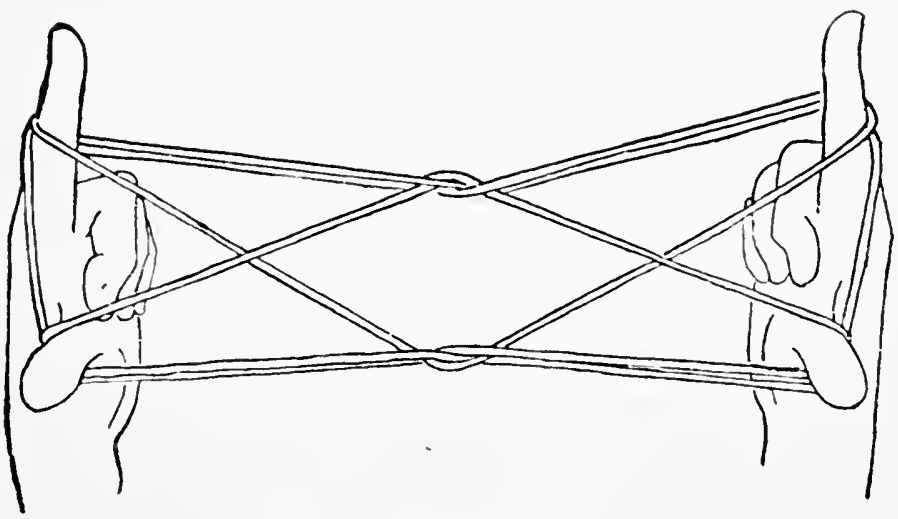

Fig. 23.-Cat's Fye, II.

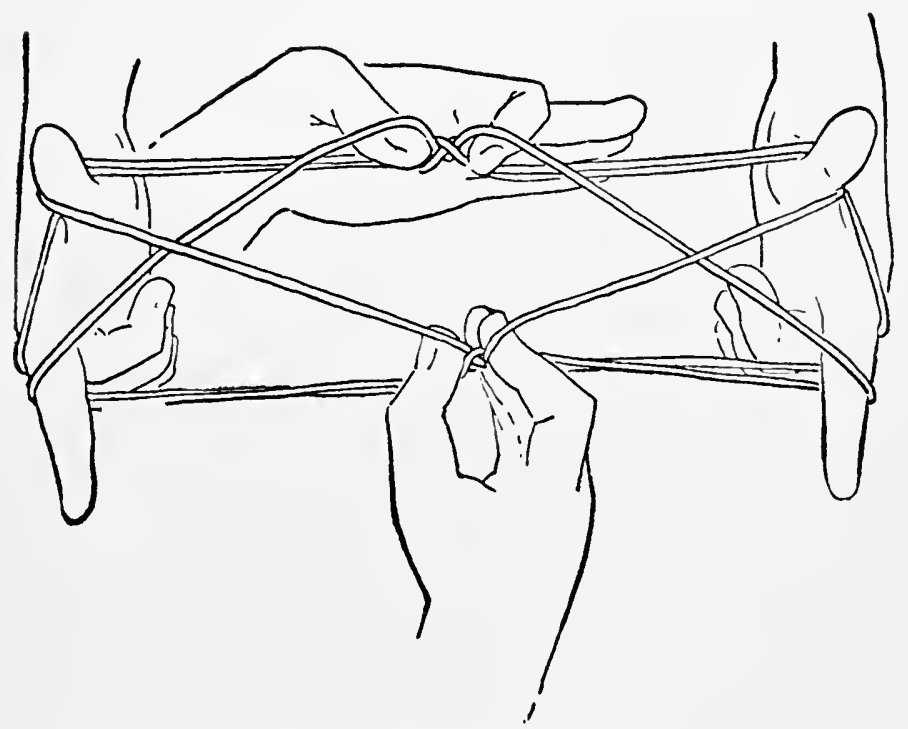

Fig. 24.-Fish in a bish, I. 
produced by the thumb and index loops, which may be alled the near and far right, and near and far left triangles.

\section{(7) Fish in a Dish.}

Synonyms: Tjyel-kon-kong-i=Rice-mill Pestle (Korea) ; tsumumi=a :Insieal Instrument (Japan).

"A" inserts the right index from above into the far left triangles, and his right thmub from alove into the far right triangle, his left index from above into the

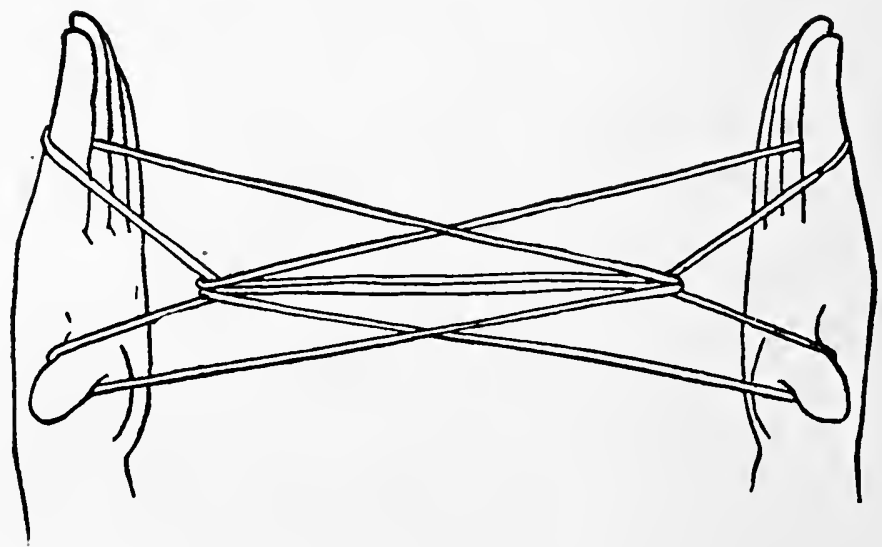

Fig. 25.-Fish in a Dish, II.

near loft triangle and his left thmul from alvowe into the near right triangle: then turning the thumbs and

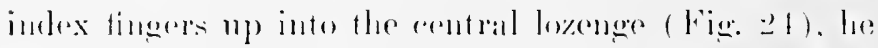

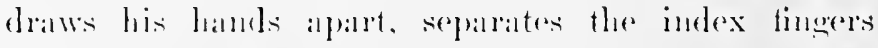
widely from the thmmbs, and takes the figmee from

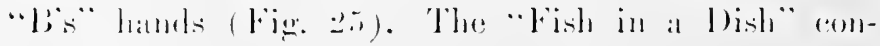


sists of a large central lozenge, divided lengthwise by two straight strings; and right and left near and far

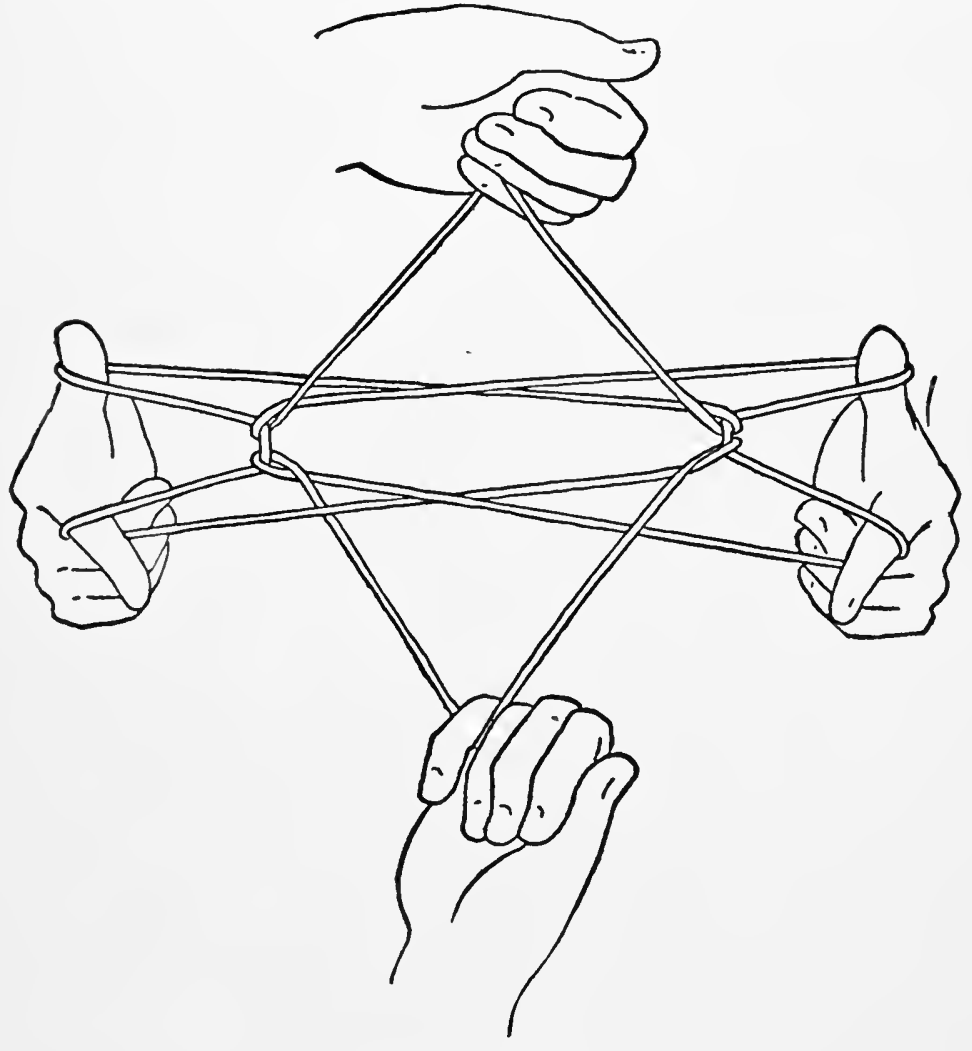

Fig. 26.-The Clock.

triangles. There is a loop on cach thumb and a loop on aach index, but nu string passing aceoss the backs of both thumbs and index. 


\section{(8) Clock.}

My father, Dr. IIorace IIoward Furness, tells me that as a child he ended the game of "('at's-cradle" by forming the "Clock" from the "Fish in at I)ish," in the following nammer:

First: "B" arranges the two strings which pass from

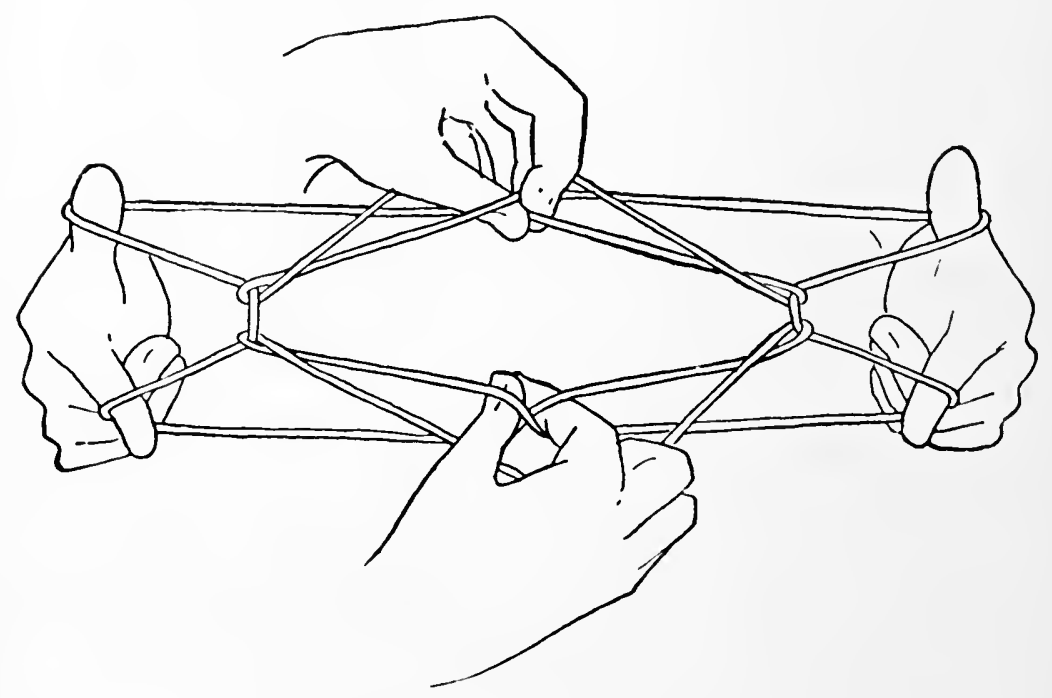

Fig. 27.-Clock.

side to side thronght the entral lozenge so that. wh-

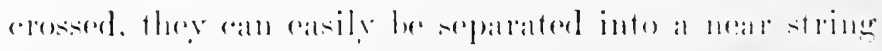
and a falr strine.

Serend: "T?" now turns his heft hand with the palm far.ing upward, and picks up in the bend of the lof little 
finger the near string which passes through the central lozenge, and draws it over the other strings toward " $A$;" then turning the right hand with the palm facing upward he pieks up in the hend of the right little finger the far string which passes through the eentral lozenge. and draws it over the other strings away from ". 1 " (Fig. 26). Putting the right thmb from above into the right far triangle, the right index from above into the left far triangle, the left thumb from above into the right near triangle, and the left index from above into the near triangle, "P" turns the thumb and index of each hand toward the centre of the figure and up into the central lozenge (Fig. 25), when, by drawing the hands apart, and separating the thmmbs widely from the index fingers, he takes the figmre from ".l"s "hands (Fig. 25).

When the figure is held vertically it is supposed to represent a tall clock.

The "Real Cat "s-cradle" is capahle of some vartiation: The Philippine Liano Moros at the St. Lomis Exposition always passed from the (6) " "at s Fye" back to the (t) "Mranger" without any intervening steps, ats follows: The "(at's Wive" is on "A's" hands. "ll" pieks up in the bend of his right little finger the string" which passes between "A "s" left thmml, and index. and lifts that string off ". " $s$ " left index only": in like manner he picks up in the bend of his left little tinger the string which passes leetween ". 1 "s" right thmuls and index, and lifts that string off " $A$ 's" right thmub only" ; then, still holding each string in the bend of the little 


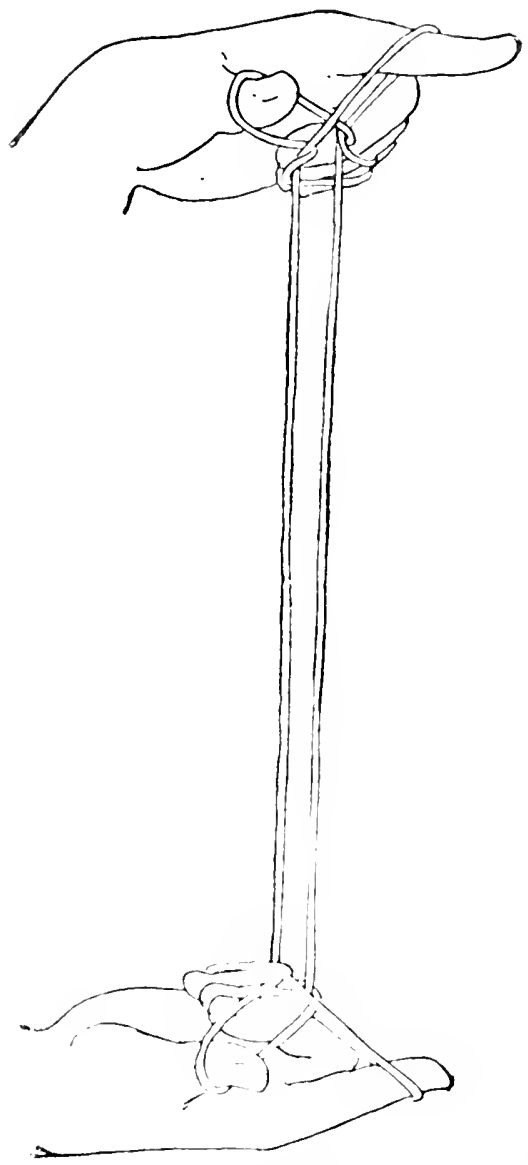

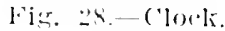


finger, "B" puts his right thumb and index (held close together) down into the figure, near " $\mathrm{A}$ 's" left hand, and then up into the central lozenge, and thus picks up from below on these fingers the crossed strings of that side; in the same way " $\mathrm{B}$ " puts his left thumb and index down near " $A$ 's" right hand and then up into the central lozenge, and thus picks up from below on these fingers the crossed strings of that side. The figure is now taken off " $\lambda$ 's" hands and extended as the "Manger." This may be the way that the Koreans, according to Dr. Weir, pass from the (6) "Cat's Eye" to the (3) "Candles." Apparently Japanese and Koreans pass from the (3) "Candles" to the (6) "Cat's Eye" (see Culirr, 2, p. 30), but I do not know how it can be done without an intervening figure. It is possible to jump from the (1) "Cradle" to the (3) "Candles" ly picking up the erossed strings as if for the "Soldier's Bed," but putting the fingers down into the figure, and separating the hands; then the "Candles" are held, of course, with the fingers pointing downward. We can pass direetly from the (2) "Soldier's Bed" to the (6) "Cat's Eye" ly picking ne the crossed strings from below, lninging them armul the side strings and down into the centre of the figure, and then separating the hands.

\section{KNOTTING.}

Tn his exeellent little loxk on Knotting and Splicinge. Mr. Panl X. Mashelek sals: "From the beginning man-

1 Knotting and Splleing Ropes and Cordage. By Paul $N$. Hasluck, 1909, Cassell. 
kind must always have used some kind of knot to join animal sinews, plant fibres, or hide strips which, in ancient days were the prototypes of the varieties of (a)rdage now enployed." Ile further states that as lives and property have leen sacrificed ly ill made knots it is important that all of us should know how to make knots best suited for our purpose. Most of us have probably seen some aceident dne to a faulty knot, even though it was nothing more serions than a loose show string or the spilling of the contents of a lundle of fresh laundry.

The nip is the most important thing about a knot, and is the part which is pinched by the pull on the come and which holds the knot.

A bight is a loop formed when a rope is bent hark on itself.

I have selected the following nine knots (Fig. 29) : at being the most important from the standpoint of ocentpation, as all of them. aside from any special use which they may have, are nseful in making ormandental or useful articles of string. At the same time the first five ane clissed as useful knots and the last four as fancy knots. There are. luwerer, many other useful and omamental

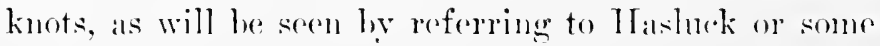
other book.

Probahly the simplest knot is the overhand knot which is most frecpuently used to puresent the end of al rope or ard from mutwisting, or mulaying, as it is terlonically called. It is made by bending the rope hatek to form a loop or light, passing it under and orer the 


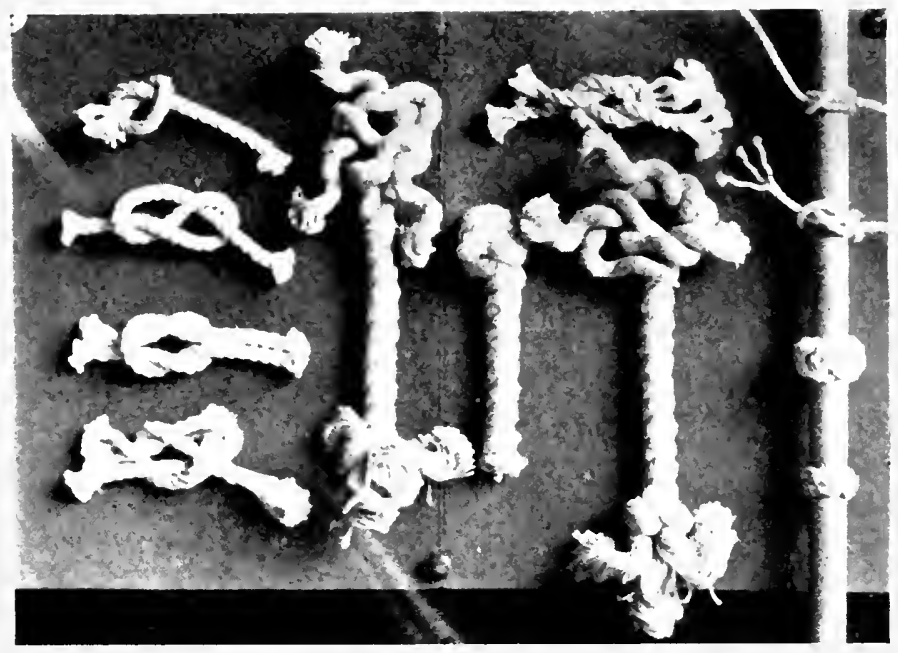

Fig. 29.-Knots.

On lhe lefi, at inp, is an overhand knot: below a figure-offirchi, rept, and wearers. To the risht of these is a crown linot bring formed and pulled taut belosi. ln the midele is at wall and 'rown, or manrope lnot. The lower end of the rope is served. Hbove is a sranny, ant the thicker rope bebow shows a wall knot being formed, and pulled tant. On the

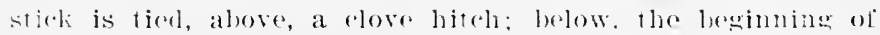
the turk's head, shown complete below. The smallor is in better proportion to the stick, but does not show its formatioll st) (*) 

stem and through the looped portion. When partly made it has very much the appearance of a pretzel.

If the loose end is earried through the loop 2.,3 or 4 times it becomes a double, treble, or fourfold knot. which is lirrger than the simple overhand knot.

1 figure-of-eight knot is made ly passing the end of the eord back, over and around the standing pilrt or stem. and down through the loop.

1 very common and important knot is the square, true, sailor's or reef knot which is used to join the ends of cord. To tie this take an end in each hand, eross them, laving the left on top of the right, which is hrought over and under the left. Bend the ends back on themselves and pass the left end, which is now at the right, over and under the right. It can be seen that we now have two loops which interlock and bwth the stem and the end lie on the same side of the opposite loop. I rery common mistake is after bending the ends back on themselves to pass the left end (now on the right) under and oier the right. This brings the stem and the end on opposite sides of the loop. It is a poor knot as it will not nip until the first portion nade has been pulled and. therefore, anything which hais been tied together is not held tightly. It is callenl a lubber's knot or gramery and is said to be nsmally tied ly girls. To mutie a sinutre knot quickly, pull the stemt and end of the sime side. The description of these knots may appear complieated, although they are very

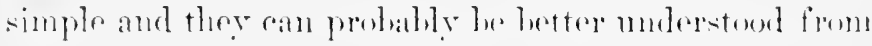

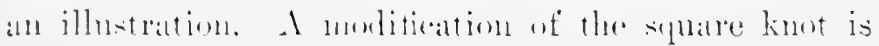


the surgeon's. Trake an additional turn of the right end, over and under hefore bending the ends hack. This prevents slipping.

A weaver's knot is a modification of the spuare knot. in which the end of one side does not lie parallel with its stem, but erosses under the stem and lies on the opposite side of the loop which retains it - that is, the loop of the opposite side. Weavers call this the thmul, knot beeause they make it over the left thmmb. It is nsed to join the ends of broken warp. The same knet is used by netters to join the ends of the twine, and it is the same knot which is made by the netting needle. The knot is properly made as follows: The two end; are erossed over the loft forefinger, the left lying orer. the right, and held by the left thmmb. The right stem (from the unworen warp) is then brought orer the

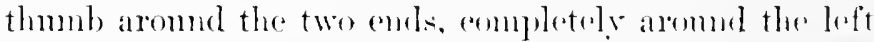
end (which stands ne to our right), and so lies between the two ends. The left end is then pusherl hatek muder. the loop lying over the thmulb, the right and and the right stent are then whased towether and the knot pulled tallit.

1 clove hitch is used to falsten al brat to al stake on

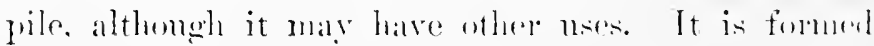

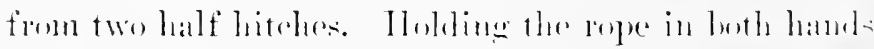

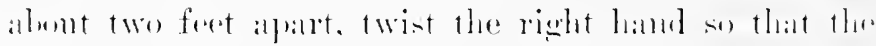
repe betwern the hands twists into a ringe the left side lying alove the right. Slip this orer the stake, maks

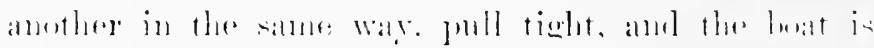
firmly moned. To mufasten lnesen the nip and side, 
the rope to the top of the stake, when the rope will naturally fall straight. This has the adrantage of being quickly tied and untied.

The following knots are usually classed as fancy, or ormamental, in distinction from the above, which are classed as useful.

The first is the wall knot, the seeond the crown knot. They are frequently combined to form a finish to a rope or eord. The rope or cord must first be wrapped with several turns of string which is tied about it at a point where we wish the knot to come. The rope is mulayed to this point. Make a bight with one strand, hold this to the stem, leaving the end free, which is passerd mitside the next strand which is bent over to form a bight the same as the first. the free end passed ontside the third strand. which is bent over it and the end passed ontside the first strand and up through the bight which it forms. The ends are then pulled tant and the ends ent off close. The crown knot is made in the same way exeepting that the free ends are brought inside of the next strand which is then hent over to form a bight als above. It may assist in fixing these knots in one's memory to asseciate that the ends form a bunch in the centre in the wall knot and that they are all separited in the crown, the end of the latter knot being that like the arown of the head. Vardons ambinations of these two knots may be mate, the most rommon being a wall and a crown which forms a manrope knot: a denlle wall, a double crown, or a donble wall and a donble crown which forms a tack knot. 
A Turk's head is a very olnamental knot which is formed on a repe. or stick, with a piece of smaller stuff. One of the shoe duster's, to which I have referred (p. 92), had a Thurk's head made of rane. and probably all have seen walking-sticks or umbrellas with this ormanentation. The simplest way to make it is to first make a clove hitch loosely. The right end is much the longest, and this is passed around the lower hitch, coming out hetween the two hitches. The upher hitch is pulled orer the lower. The loose end is passed around the upper hitch and comes out between the two hitches, fixing their position. The lower hitels is then pulled over the upper, the loose end passed aromd the lower and roming ont hetween them. This alternate "rosing of the hitches with the interweaving of the loose end is rontimued until the ciremuference has been made, when it will he found that the next move of the loose end will parallel it with the right end. From now on the loose end is simply woyen in and ont alongside of the strand where it maturally falls. until ralel seromp contains three strands. The longth of eord munt be more than nine times the cirmunferenee of the objeret aromel which the knot is marte.

The next knot is the Solomon's knot which is 11sed moniderably in marelame work. Tt is simply a stpure knot tied on a deader, and is ansidered in detail moder Malcrallir.

\section{SERVING OR SEIZING.}

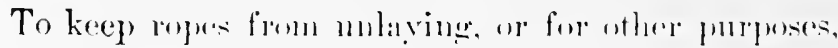
they are wrapped with twine. and areneding to the 
mamer and position various names are given to this cperation. What I had always known as serving I found, on studying Itasluek, is end seizing. It is used 10 prevent ropes from unlaying where an end knot is undesirable, and is easily done. IIolding the rope to be seized in the left hand with the end to the right, at ahout an inch from the end take several turns about it with a piece of strong string, holding the left end of this in the left hand and winding with the right. Ifter three or more turns have been made, turn back the left end and wrap it under. Then the wrapping or seizing las come nearly to the end, lay the wrapping cord down and wrap it in for a half-dozen turns. Pull taut. cut off all ends and the rope has a neat finish. If the middle of the rope is being wrapped. when it is desired to finish off, lay in a bight, preferably of the same sort of cord, wrap it in, leaving a loop at the end through which pass the end of the wrapping cord. Pull one end of the bight and this will pull the cord under the wrapping and so fasten it.

\section{BRAIDING.}

liraiding is really a form of weaving, and we are fmolnly most familiar with the three fold in the form "ff "pigtails" on our little girl friends, although it is sairl that the same little girls when grown up are in the halbit of putting their hatirs to leed in this salue form. As most everyone knows. the three fold hraid

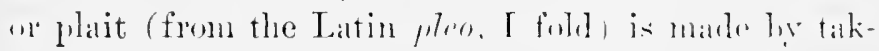

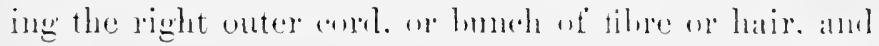


passing it over the next and under the third. The third strand, which has now become the middle, is then passed muder the sceond in the opposite direction. The first is passed over the second. The third over the first, ete. The process is a hending of the outer strand over the middle one, the bent strand heoming the middle and being bent orer ly the onter strund of the opposite side, this being kept up until the braiding has been aceomplished for the distance desired. Most of us have acquired this accomplishment eary in life and it has become somewhat of an antomatic movement. When we wish to braid four or more strands in a tlat braid it may seen diftienlt to us. hut if we have mastered the principle that it is a wearing it will after very hrief practice become automatic. It is easier to work out these braids than it is to follow directions. In beginning to braid fomr or more we have to start the strands in pairs-that is, the first and third are laid over the second and fompth, the two midlle ones (the first and fomrth) are crossed, the third is bent hack orer the fompth. and we have thee strands lying to the loft. Fend the one to the extreme leaft hatek and

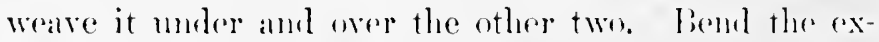
treme right hand and over the mext, whirh again gives us threestrands in the loft hamd, and the proessis is a repetition. In starting the five strand braid the first and secomel. and third and fomrth strands are eposed in

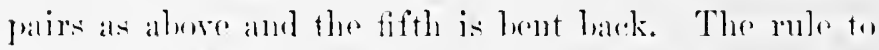
start all hraiding may le said to cross in pairs, then rerosis the milllle pair, after which it is simple wrats- 
ing. Braiding is easier to learn if strands of two or four different colors are used, as then any irregularity in the braiding becomes at once apparent. These braids may be used for various purposes and are especially effective when made of paired strands.

A variation from the 4 flat braid is the 4 round, which gives a thicker, stronger and more ornamental cord than the constituent strands. Two persons can do this much more easily than one, and it is more easily learned if two colors are used. The ends of the four strands having been fastened to a stationary object, one person, $A$, takes the two strands of the same color, one in each hand and crosses them-that is, the right hand strand is put in the left hand, and vice versa; the other person, $B$, then erosses the other two strands over that made by $A$. A crosses the cords over B's, and this is eontinued mitil the length desired is made. All braiding should be done fairly tightly to appear well.

1 different form of lraiding, which is nsed by sailors to make mats and chafing gear is deseribed in IIasluck's book on page 121.

\section{SPOOL KNITTING.}

Spool knitting. which some of us learned in our (hildheod, mily be enjoyed hy some patients, but the falct that the end product has little value is a serious drawharek. Formerly the oord which wals woren by this means wats used for dhildrents reins, but the faret that

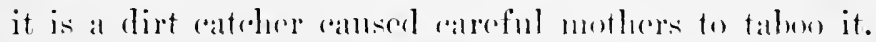


I have seen an afghan made of these cords which had been sewn together side by side, but it was not as attractive as those knitted or erocheted. The cord may be useful for some speeial purpose, however, and a knowledge of how it is made can do ns no harm. Into the end of a spool drive five pins, or brads, expidistant. Wind the yarn or string, which is the material used. twice around these pins. Then with a stiff wire or fine erochet hook pull the first course orer the upper and over the top of the pin. Contime this, and in time the woven eord will pass through the hole in the spool.

A special spool for this work caln uslally be purwhased at toy stores or where yarns are sold. This hals four staples on which the knitting is done, instead of the five pins noted above. On accomnt of there beiny an eren mumber the work must be started differently. The string is carried around each staple instead of across it, although after the start it is earried across in the usual way. The cord made is less of a romul than when done on five points, and mily appear square.

Certain variations may be made. surels as not earrying the string across one spare. hut going balek and forth. Or the work may be done on there or two pins only. Or the string on one pin maly be slipped eff lefore carrying the string aneross it, so that noe stitell is taken. This is pullerl out when finisherl to make a sort of edging.

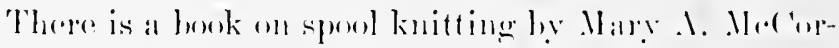
mark. lunt I ann not familial with it. If the patient 
shows a liking for spowl knitting this should be consulted.

\section{RAKE KNITTING.}

Rake knitting is an improvenent over spool knitting, and with it many useful and attractive articles can be made. It is described by Miss Tracy in her book on page 4 .

Very attractive bags are made of a special hard finished cord. Soft cotton cord is not suitalle for rake knitting, although yarn is excellent material with which to knit.

\section{STRING DOLL.}

This is a modification of a tassel. Tsually a book or piece of wood the length that it is desired to make the doll is selected and the string, usually white knitting cotton, is wound about it until it is of the required thickness. When the string is cut along one sile. This "ut portion is laid down carrefully and unfolded to its full length. A piece of string is tied firmly abont the middle. The bunch is then folded over this cord so that it is entirely covered. Two portions are kept ont to form the doll's plaits. String is tied about the remaining portion to form the neck. Two portions are selected to form the arms. Another string tied alont the bunch forms the waist. If it is a lady doll we are making, nothing more is necessary than to finish our plaits, tie and cut off the arms at the proper length, and mark eyes, nose and mouth with pencil or hack thread. If we desire a loy doll, no portion is left 
ont for plaits and the end is divided to form legs. One of my pupil nurses made an Indian ly using red string which was covered with brown string from the neck to form the clothing. Plark and white yam formed the head-dress. Many varieties can be made in this way.

\section{SHOE DUSTER.}

A more nseful article is made in much the same way. I hamdle about 18 inches lome is selected and may be ornamented in any way desired. It is notehed completely alomed alout a half inch from tho end. The eut strings. Which should ler at least 16 inches long, are tied firmly into this notah at their midnde. The upper portion falls over the lower and is tied about the whole bmuch lelow the end of the stick hamdle. A lowp or ring is fastened to the uplere end of the hamdle and it is lomen ontside of the fiont door. in order that one may dust their shoes before enterine the house. ('arpet warp which romes in a great valuety of colors can be used. or cofton string. If the desired shade camuret be bought the duster cam be made of white string and lyed. The handle cam be derorated in many ways. I have seran them wralped with cance, painted or carved. Sume very attractive ones have been on sale in thes sheps.

\section{MACRAMÉ.}

Malramb is a rariety of string work which was very

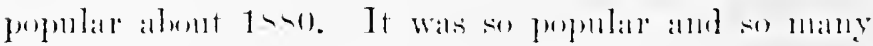

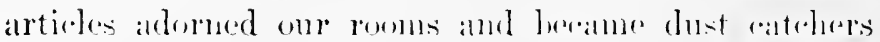


that there came a revolt and it all disappeared. Recently there has been a revival of it, and bags made of raffia have been used for several years. Some macramé is very beautiful. Louisa Walker says (p. 160): "Mracrame or knotted lace is of very ancient origin, and was much used for ecclesiastical purposes in Spain and Italy in the 16th Century. In the time of Queen Mary it was made on a pillow and was used to make ornamental corers for handbags and other articles which were lined with colored silks. The word macrame is of Arabic origin and was applied by the Italians to the ornamental fringe produced by knotting the ends of their coarse towels; a more appropriate term is knotting." The book from which the above "putation is mide contains directions for macrame and a number of other attractive things, lut also shows many horrible examples of what can be done with string.

Macrame is best worked on a board to which the doubled strings, called leaders, are tacked, or they may be "'ast on" a stick ly lering looped orer it. The cord is lent into a bight which is passed over the stick and the two ends are passed through it and pulled tant. This is sometines called a slip knot, but is really a rmminge knot. The so-called malerame knot consists

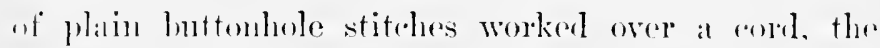
leatler, which must be held tant while making the kint.

1 Wallere, Lomisa. Varied Occupations in Stringr Work. London, 1s96, Macmillan. 
Seine twine is usually used. This eomes in several sizes and colors, and may be dyed if desired.

For specific directions for making articles in macrané I would refer to Lonisa Wialker's book or some other work especially on the subject. I have, however, thought it best to give the direetions for making a maeramé bag as it is an excellent exereise in knotting, and when made with raftia makes a useful article. There are a number of so-called "bars" (Fig. 30) which are used in the work which may be applied to other forms. These are shown in the accompanying plate and are rather simply made. As is shown, they are all made on a leader. The first, called corkscrew. consists of a buttonhole stitch to the right-that is, the working string is earried over the two cords which form the leader, around under it. and through the loop formed by itself and pulled tant. The knots: which this forms naturally arrange themselves spirally about the leader, hence the name corkicorew. To insure a uniform twist the string is passorl bark and under the leader at every sixtlı stitch.

The buttonlole bar is made by a buttombole stiteh to the left and the knots are kept in line and not allowed to fall spirally.

The simple fienoese bar is malle ly single hutomhole stitrhes alternating to right and loft and is madr with two strings. hesides these forminge the leatler.

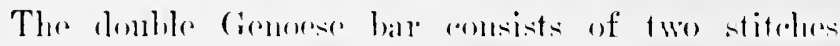
workenl alternately instead of one. Varrations can he madr ly using :?, 4 , 5 or 6 alternately. 


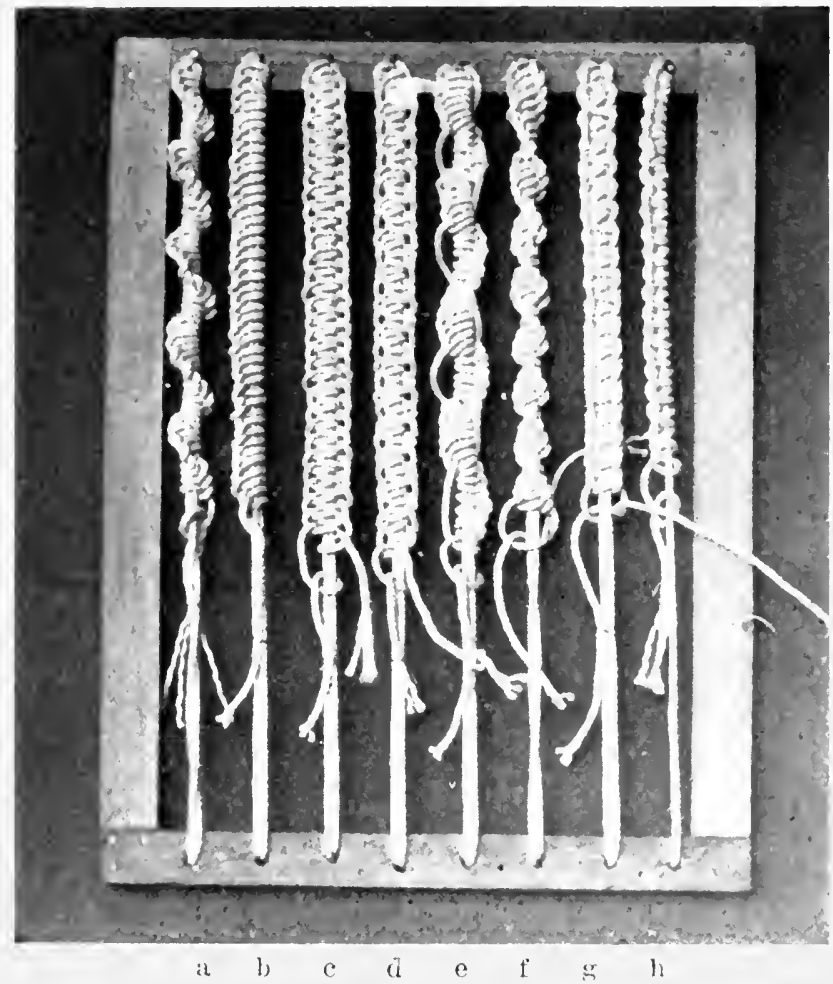

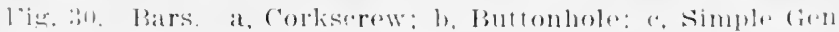

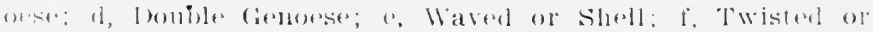
l'antister: er, Solomons:s, h, Taltedl. 
The waved or shell bal is made by making (; buttonholes to the right or left and pushing them elosely together, naturally the cords on the unknotted side will approximate more closely and the bar has a eurve. The next six stitehes are taken with the other cord on the opposite side giving the waved appearance.

The twisted or banister bar is made by passing the left tying cord over the leader and under the opposite tying cord. This is then passed under the leader and over the first cord. This, will naturally fall into at spiral.

The Solomon's bar consists of a series of square knots tied on a leader and is made by passing the left tying cord orer the leader and under the opposite tying cord, which is then passed under the leader and over the left cord. This is then passed under the leader and over the opposite cord, which is passed over the leader and under the opposite cord and pulled tant. The next knot is tied begimning with the right string.

The tatted bar is made with a single cord and consists of two buttonhole stitches reversed to each other. It is made by taking the knotting cord over the leader in the ordinary way, i. e., orer, under, and up throngh the loop and pulled taut. Next take the cord under. then over the leader, and down through the loop. I donlle tatted bar with two strings worked alternately is more effective.

All of these knots and hars may lo used to make attractive and useful articles. One of the simplest is a wateh foll. 
Watch Fob.-To make this take four pieces of No. 10 seine twine abont 20 inches long. Double two of them over a hook, or oflece stationary point, to form the leader. One and a half inches down begin a Solomon's bar, which make for 1.2 ineles. With the strands in pairs tie a wall knot. One and a half inches from this tie a manrope knot (wall and crown) and cut off ends, leaving alont an inch to form a sort of tassel. This makes a nsoful fob which can be washed or thrown away when soiled as it is inexpensive. If seine twine is not availalile any form of string ean be used. Many variations can be made, using the knots, braids, and bars which have been given. I four fold flat linid with the cords in pairs is very handsome.

Watch Guard.-I once saw a very handsome watch guard made from $N_{0}$. 32 seine twine. and was permitted to take the following measmonents from it. It was leantifully made, ladd heen frepuently washed. but was still nost attractive. Tufortmuately I cannot give the longth of twine requiled lont womld inagine that the eight aonstituent twines shonld be at

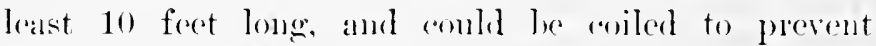
tangling. The two ends wore fastemed to a ring witl at snap look, and the total longth was ie inches.

S strings, 10 fort longe. Lomp 1! in. outsile; :) in. of loose tring; $; 3$ in. Solomon's knots: a cown knots ;

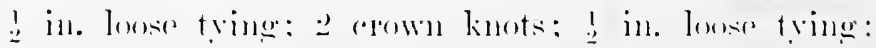

1 By loose lying is meant that the cords, divided into two gronjes, are tien as for several spluare linots or gramnies willout pulling the strings tall. 
2 crown knots; ; in. round hraiding; 2 erown knots; 3 in. loose; 2 figure-of-eight (llat) knots (made with 2 strands of 4 each); 1 in. loose tying; 2 crown knots; $2 \frac{1}{4}$ in. Solomon's knots; 2 crown knots; $\frac{5}{8}$ in. loose tying; 2 crown knots; 5 loose tying, 1 erown knot; $3 \frac{1}{4}$ in. spiral $;+$ in. loose tying; orerhand knot (centre). Reverse the above directions.

Macramé Bag.-A beautiful bag can be made with seine twine, altlough the same may be made with rattia (Fig. 31) and has the adrantage of being lighter. It forms the onter covering of a bag made of colored material and is useful for carrying knitting, etc.

To make a medinm sized raffia workbag, first take one strand of raffia and on this piece at the centre tie five strands of raffia of the same length and width with a slip knot. Then tie the first strand of raflia used, bringing the east on pieces together so as to form a snall centre ring. This gives six louble strands of raffia. On each donhle strand tie seven more strands (the form of tie being a Solomon's knot). This is the foundation of the bag. Sew it firmly to a round piece of cardboard, the size it is desired to make the botton of the bag. The strinds tied hy means of the Solonon's knot will lie half on one side of the double. string, or leader, and half on the other. 'Take the seven strands lying on one side of the leader with the seren of the mext sot which lie next to it; this, with one from calch loader makes sixtron strands of rattia with which to work.

1 sate plan is to make the divisions just indicated 
all the way around the circle, tying each set in a loose temporary knot.

Leave ont the two strings on each side which are farthest from the centre-that is, one of the double strands and the last of those tied with a Solonon's knot. The next strind in the row of Solomon's knots. or sixth, is the strand with which the next tying in done. Gather together the strands from loth sides of the remaining five Solomon's knots, lay them down in order, and with the strands from the sixth make a Solomon's knot aronnd them als a leader. This forms one-half of a diamond. Take each of these strands and tie to the seventl string on the same side, using the buttonlole stitch or knot. Slanting the same string parallel with the opposite side of the diamond, on this string tie in order, five on each side, with the buttonhole knot, the number forming the second half of the side of the dianond. The two tie strings are now tied together with a square knot. This gives seven strands on each side of the diamond. On the eighth strand (the one loft on eachl side) tie these seven in the same mamer, pulling the knots up close to the first row of knots. Tie the tie strings together as before. This forms one complete diamond. The rest are made in the same manner. When all sections are tied it should form a six-pointed stalr.

Spreat the work ont flat, tie all strands in order to a ring of reed, first passing it completely around the ring, then tying with an overhand knot. Another ring may be placed outside of this in the same way. 


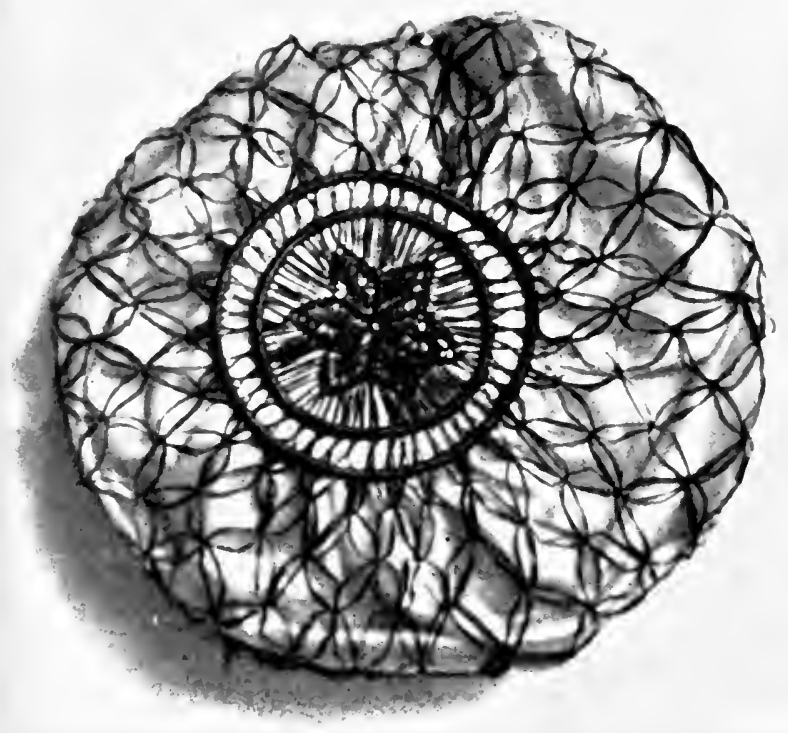

Fig. :1.- Raffia Rag. 

If the bottom is to be quite large, another row of diatmonds may be made outside of the first row. These will lie at right angles to the first row.

Divide the strings into sets of fours, using the two outer ones to tie a Solomon's knot over the imner ones. Do this all the way around the ring at any desired distance from it. Again divide in fours, using two from each group, and tie in the same way as many rows as desired. A pretty effeet and a better bag is obtained by making these rows of knots elose to the ring and gradually inereasing the distance letween them.

Work out until the size it is desired to make the hag is attained, or until there is remaining three or four inches of each strand. Gather two adjacent Solomon's knots and with a new strand of raffia make a Solomon's bar and at the end bend back to form a leop. Io this all around the bag. thus forming the loops for the drawstring. The latter is braided flat or round as preferred. Two are used, being inserted at opposite sides and rumning through all of the loops. Tie ends of the draw string with an overhand knot and fringe out to form a tassel.

It will he noted that in the instructions which have heen given there has been a gradual development from simple things to more complieated. and ly embiniltions to still more complicalted. It is so that we learn and develop montally, and it is this plan which the nurse should pursue in ocenpying her patient. She maly hatse to stop for a long time at a certain stage, but this should not discourage her. Any aceupation 
which begins with simple things and becomes more (omplicated is what I call a dercloping oecupation and is especially valuable for use with mental cases.

There are many nore things which ran be done with string and a knowlonge of which the murse must acquire from other soures. The most valualle things are netting, tatting, "rocheting and knitting. The last three are especially valuable because they usually require counting and rlose attention. For the sane reason they maly be fatigning. They are all much more easily accuired under a teacher than from descriptions, but the following references are given in case a teacher is not possible.

Setting.-Iisluck, p. 125. Walker, p. 116.

Tatting.-The New Ileary Thread Tatting, Woman's Home C'ompunion, May, 191:3.

Kunitting.-Trerseher's Mammal.

Crochetingr-Floischer's Manmal.

IIairpin ( recheling.-Walkire p. 240.

Hair-pin crocheting is recommented as a simple form of work which ean be done ly hed patients or those who are montally incapalble of doing the more emupli-

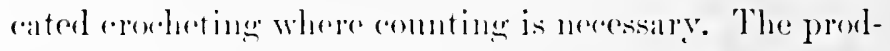
uet is noseful and ran le joined together to form many articles, or is used ats an elging. 


\section{WEAVING.}

As one studies about weaving one learns that the word loon may indicate a great many different objects, and probably the broadest meaning is, any object which holds threads in such a way that other threads may be woven alout them so as to form a fabric. The fixed threads form the warp and the other threads the woof.

In playground work weaving on a pasteboard loom has been used to make doll's hammocks from string. 1 loom of wood and wire is now supplied for this purpose, hut pastehoard is almost as satisfactory. To make a hammorek take a pice of pastehoard the size that it is desired to make the body of the hammock and cut notches along each end a guarter of an inch apart. The usual size is alout 8 by 12 inches. Take two rings about an inch and a lalf in dianeter, or make them from twisted wire, reed, or twigs. and fasten these to the centre of the pasteboard by tring. Fasten the end of the warp to one ring, pass it over the end notch to the eorresponding noteh on the oppersite end through the second ringe, then bark to the next noteh, to the corresponding not hy on the opposite and. thromgh the first ring, kepping this up mitil one side of the pastehoard is covered with strings lying parallet. al cuarter of an inch apart. Strings which alre ent a little longere than the hammonek is wide are then woren 
on the warp, it being possible by varying the color and weave to make many pleasing patterns. If it is desired that the hammock should not have a fringe, the woof is a continnons cord. The weaving can le done more easily and rapidly if the woof is threaded on at needle (Fig. 32). If the ends of the pasteboard are curved convexly the hammork will liave a sag and the doll will not he so apt to fall out. When finished the string holding the rings is eut and the hammock slipped off the pasteboard. While simple, the work is interesting and the weaving is excellent training for the attention. If the hammock is made for some particular little girl's doll the patient will naturally take more interest in the task.

This form of wearing can be adapted to make any woven article that we wish. For example, suppose we wish to make a pointed cap, such as used to be known as a tologgan cap. from yarn or worsted. The will make this fifteen inches long, so tie a pencil to a piece of string and fifteen inches from it tie an overhand knot and thrust through it a pin. which place in the corner of a pice of pasteboard and with the pencil draw from one edge a eurve. Text measure around your own or some other convenient head and mark laalf this distance on the curve drawn. From this point draw a straight line to the corner where the pin is attarbed. Cut off this comer about half an inch and make a broad notch. Cut ont the pastebard and along the rurved edge make a series of notches. These should he a half inel apart for heary yarn and 


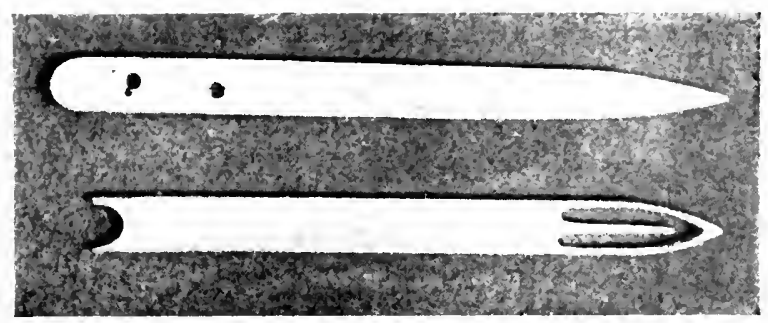

Figr. 83.-Wooden needles for weaving. Alove is the noedle for simple weaving; below is a netting needle. 

less for lighter ones, those at the two edges being half the distance from the edge that they are apart. Fasten the yarn about the tirst right hand point of pasteboard which lies beween it and the next noteh, so that the long end is directly orer the first noteh, then wind the yarn to the noteh on top and down the opposite side to the first right hand noteh on the other side. Pass the varn under the point of pasteboard to the next right hand noteh, over the point, down the other side to the next right hand noteh on that side, around the point to the next notch, and so back and forth until all of the notehes have been filled and the warp lies evenly spaced on the two sides. The wearing is then done around the loom with a continuons thread, interrupted to put in the pattern desired. When finished the pasteboard points are broken off and the form slipped out. The cap is reversed and finished with a cord and tassel. If mide shorter, the upper end must be broad and notched with the same number as below. This is drawn together with a drawing string. These looms, already prepared, with directions and materials. may be procured from the school supply stores.

The number of threads in the warp nunt be nueven, which is easily managed for the hammock. lut is more difficult for the cap. Probably the simplest plan is to run an extrat thread to one of the notelies. but this has the disadvantage of making an meven place in the weaving. The difficulty may be orerome by having the notely on one side at the same distance from the edge as the distance hetween notehes. and ruming the 
extrat thread along the edge where it may be seenred with a pin.

The next development as a loom is a wooden frame with notches or brads in the ent pieces arer which the warp is strung. There are a mumber of different forms of this loom on the market, among them the Faribant, Todd, Trindall and others. ${ }^{1}$

There are also a mumber of hand looms (a hand loom is any in which the shuttle is moved ly hand) on which rumers. rugs, scarfs, curtains, or other useful and beantiful articles may he woven. Work on these looms shonld only he undertaken after some instruetion has been receiverl, although alunost anyone with a slight knowledge of weaving ean learn how to work one of these loons from a book of instructions."

Wearing is one of the best oecupations there is, and especially on one of these larerer looms. for the eonvalesent or the ehronic ane in when there is little mental reduetion. In its higher forms it is at distinet eraft and rexpires akill and gond taste in the mechanieal part of the work and in the selection of designt. color. ete. It is guite proper that it be rroed as a lobly for one who sluws a liking for it.

The Indians wove heantiful hankets an a vere comlde loom, and most heatutiful rugs are made ly Persians

1 Todd, Natlie Phipus. Hand loom weaving. Now York and Chirago, Rand, NoNally \& Co.

:Hooper, lemher. iland lom weaving. flain and ornamental. Artistic rafts series of terlnieal hambluolis. New Jork. Nacmillan Co. 
and others on a similar one. $A$ pole is suspended and carries the warp with another pole at the bottom, which is weighted to stretch the warp. Ordinary yarn or worsted will make beautiful Indian blankets when closely woven, and this can be done on a large wooden frame.

Wearing on frames such as are mentioned above can he done more easily with a needle (Fig. 32) about seven or more inches long made of wood, one-eightll of an inch thick, to which the thread is attached by ruming through one or two eyes in the blunt end. The thread may be almost any form of string or rags. Some beautiful rag rugs are made by twisting two strands of different colors together before wearing them. The preparation of these rags is a good ocenpation itself.

There has recently been revived an old way of making tidies (which I understand no longer appear in our hest households) or mats to be placed on polished taliles to prevent their being marred by hot dishes. Frames of thin wood on which to make these may be purchased with notches on the four sides to aceommurdate the string. or a frame can be made of the size desired and nails driven in the sides an inch apart. about which the string is wound. Tsually a soft white knitting eotton is nsed and is fastened at one nail, hrought across the frame and around the opposite nail and the next. anain across the frame until all of the mails lave heen used and we have a series of parallel cords stretehing across the frame, which is turned and 
another series of eords are wound on at right angles to the first. This vinding is continued until the rows of cords are about a half inch thick. Ther are then fastened together by means of a cord which may be run diagonally across the open square or run parallel with the intersecting cords. The diagonal tying is done twice and nilkes the mat stronger. I netting needlo (Fig. 32) makes the operation much easier. and is usually of one-eighth wood ahout six inches long. onehalf wide, with a broad notroh at one end and a blunt point at the other. Barek of this blunt point about ant eighth of an inch the wood is cut away for about an inch and a half, leaving a tongue in the centre. The rord is lield on the needle, brought around the tongue and down the satme side, so holding the end under it. over the lroad noteh, up the other side, around the tongue, down again over the noteh, and so on, not (rossing itself. until the reedle holds all of the cord which it will accommodate. $\mathrm{By}$ its use we have the rord coiled, as it were. In tring the intersections of the mat the free and is tied about the first intersection with a square kuot, the needle is passed orer the next intersection. up through the space towards the knot last tied. over and muler itself. making an overhand knot. and pulled tant. ('orl is moniled from the needle as needed. When all intersections are tied the cords are cut from the nails, trimmed evenly and our mat is finished. If a frame is used witlout nails the cord is wound over and over it and after tring is ent at the edges to take off the frame. 
The diagonal tying is used twice on a tidy, the mat turned over and half of the strings are eut through midway between the interseetions. With the handle of the seissors passed to and fro over these ends, they are fluffed out and make a rather pretty effect.

\section{RUG MAKING.}

A group of patients and myself once had a good deal of pleasure in making two rugs in the Persian manner from some carpet yarn which we had aequired by donation. The warp of white string was stretched on a frame. then a row of short pieces of yarn (about :3 inches long) were tied to the strings by doubling them over a string and passing the left end over the string. under the next to the right and out, the two ends forming the pile which was trimmed smooth when finished. Varions designs were made during the weaving. Between each row of tied yarn a string like the warp was woven to give strength to the rug. 1 similar rug could be made with waste yarn or worsted. Incidentally a study of oriental rugs might be made to add interest to the occupation. ${ }^{1}$

Besides the rugs which are woren on a loom, there are a number of other methods. First, the old-fashioned braided rug, which may be made of any kind of rags made into hraid, and coiled round or oval. the

1 Lewis, Dr. G. Griffin. The Mystery of the Oriental Rug. Phila., J. B. Lippincott Co., \$1.50.

Lewis, Dr. G. Griffin. The Practical Book of Oriental Rugs. Same. $\$ 5.25$. 
edges being stitched together. The rags are cut into inch strips, or an inch and a half for a heavier rug, sewed strongly with linen thread, but not into a hard spot. I small amount is braided at a time, the work heing held in the lap, care being taken to make the sides of the braid smooth and to keep the flat part of the braid always on top. The rug is sewed on the wrong side with waxed. heavy linen thread. When made of cotton these rugs can be washed.

Another form is the hooked rug which, when made hy an expert, may he very artistic. This subject has heen trated so entertainingly and thoronghly by Ifolen Ii. Alleee that the reader is referred to her little book, ats justice to the subject camnot be done here. The work repuires a good deal of patienes and is probably a better form of oecupation for those patients in whom mental reduction hals oremred, such ats allianed dementia pratecex. inuberility or senility, than for these who are suffering from a functional prechosi.s. For the lattere nore varied ocenpations are better.

ling maly also be knitted or crocheted with centrese ueenlles from narrow rags. A silk portiere was knitted from the wolnowd selvage of silks.

1 Alber, IIelen R. Abnake Rugs, 3 Edition, Cambridge, 1309. The Riverside Press. The first edition was mullished in 1903. Mrs. Alheses address is Silver Lalke, N. II.

Miller, Katharint E. Abnake Rugmaking as a Village ln dustry. The House Beanliful, $x$, 2287, Oetolw1, $1 ! 101$. 


\section{LACE WEAVING.}

A special loom for making lace can be purchased for about five dollars, and has proved an interesting ocrupation in several instances. It is not especially difficult. 


\section{PAPER WORK.}

Like string. paper is a material that is usually arailable: therefore, a knowledge of its possibilities is important. Paper is defined as a substance consisting essentially of cellulose fibres interwoven into a compact web, made by chenical and mechanical processes from rags, straw, wood, bark, and other fibrous malterial into thin sheets or strips. It is used as an medimm for writing, printing, and wrapping, althongh ramious special uses have been devised. such as huilding. parking, etc. There are five proeesses in its manufature: (1) cleansing, (2) boiling, (3) washing. (t) blearbing, (5) heating. This gives a pulp, which is fed into malines, whenee it emerges as the finished product which we all know.

Probably the first paper was used by the Chinese in the second century I3. C. Tn 5.51 A. D. some ('hinese paper makers were captured by the Aralks and introduced its manufacture. From this tine a knowlorge of its malumfiature and use rapidly spread. It scems imposilite for us to inagine how we conld and alonge without it in onr daily life. Its commonness

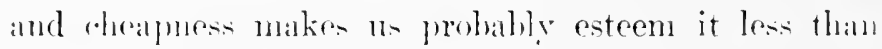
we should. The nurse and find much material that will be of use in waste palpere batsets or the wrappers of bundles. 


\section{PAPER FOLDING.}

These forms are used for the same purpose as the puzzles and catches-that is, to attract the patient's attention and interest. Some, however, are nseful.

Kindergartners, I understand, begin the paper work with a five-inch square of moderately heavy colored paper, and with this develop many forms. That color is an additional attraction is undoubted, and in all of our work, whenever possible, we should use this to make occupation attractive to our patients. Aside from this there are great possibilities in educating in color harmonies, etc. The object of teaching folding is to teach aceuracy of hand and eye.

The first and simplest form is folding the sheet in half, forming what the child calls a book. Another fold makes it a handkerchief. Folding twiee more and opening it up makes what the child calls a window-pane or a cheekerlooard. If the "book" is stood on the two edges parallel to the fold. we have a soldier's tent. If the shert is folded diagonally we have a shawl. If the checkerboard is folded twice diagonally for guide lines and the sides turned up, we have a box or tray. Folding our sheet twice diagonally marks the centre of the sheet and if. after flattening it ont, we bring each corner to the centre and fold. then turn each corner back to the middle of thre erlese and fold. we have a picture-frame. These and many other simple forms may he developed before the patient has his interest aroused. 
leference to kindergarten bonks will arld much interesting informition.

A useful paper form is the 'up, which is malde from a square, but preferably larger than five inches, as the latter size results in a very small cup. First fold the square diagonally. Text place the corners on the diagonal at a midpoint on the opposite sides and fold. This results in a pentagon. Turn down one right angled corner and tuek into the onter fold, and we have a servicealble eup with a handle.

A sheet of paper ean be folded into an encelope form. The two ends are folded down not quite a quarter. Fold down each corner. Fold each side down not quite one-third, and we have quite a respectable looking envelope.

1 fisti's mouth may be amusing to anyone. It is hest malde from paper twice as long as wide. This is folded once ealch way to quarter size. Open up and fold down the eorners. From where the comer's mont fold a diagonal to a diatrter of an inch fom the midllde on each side. Fold aleross the middle of the long axis towards the that side. Fold the turned-in ampers together and. holding the two prints together. foree in the middle towards them. The diagonal folds will allow the form to flatten, and upon then depends the sureess of the form. I slight movement will make at resemblance to the galping motion of a tislis mouth, and an reve drawn in fropere postion will increase the resemblimince.

There is a very interesting form folden from a 
square which by a turn or two can change from a rather geometrically formed chicken into a sail-boat, or vice versa. A form such as this may serve to excite the patient's interest because it brings about the desire to see if he can do such as simple thing as make this change. From this he may be indueed to make other forms. It is interesting as being a very old form, and I have been told that a eertain old gentleman in Southern Maryland was in the halbit of folding his offering to the contribution plate in this waly.

\section{FOLDING AND CUTTING.}

\section{Five Pointed Star.}

Many uses will naturally suggest themselves for this, rhiefly of ormament. Fold the paper once. Fold at the centre of the folded edge at an angle to it. leaving al portion uncorered, the angle of which is one-halt of that of the part folded over. It will probalbly take a little practice to do this, so that it is hest to use al piece of waste paper mutil we have malde our pattern. The movered portion is folded orer the other part, half (overing it. Fold this in half. With scisions's ent off the irregular ends. Dependent on the angle at which this is done will he the points of our stall, which we halse when the palper is mufolded. It is the triek which betore Rows showed General Walshington and which calused the stars in the American flig to be five pointed. 


\section{CUT OUT DOLLS, ETC.}

Probably most of us. were delighted in childhood with the string of paper dolls which some kind relative made for us, all holding hands. A piece of paper is folded over in one direction several times to the proper size, and from the central fold as a midline we eut with seissors as artistically as we are able. a half doll with arm outstretched, extending to the other folded edges which are not ent through. Lnfolding gives us a number of dolls in line. A variation is to fold our paper to a point and ent in the same way. This gives us a ring of dolls holding hands. The possibilities of this work are great. Some persons and some children are able to cut ont designs in this way much better than they can draw. One summer afternoon I kept a group of children quiet, so that their mother might have a nap. by reading one of the Oz honks, after which I rat out the chalracters in the above way, each child getting one after they were cut apart. Any simmetrical design can he matle in this fashion.

\section{PAPER CUTTING.}

Many children delight to ent ont figures of animals, ote.. with scisors. and a pationt nuy enjoy a further development of this. Very effective pictures an le made rery simply, although they must be rlaswed as impresionistic. $\Lambda$ dark green fir tree on at white ground gives ns the impression of a tree on a lill "revered with snow. One of my nurses made an 
interesting series of pictures showing a tree on a hill during the four seasons. It was made from papers "ut from a paper sample book, four pieces comprising each pieture. one for the ground, another for the sky, a third for the trunk of the tree, and the fourth for the foliage. Much more elaborate pietures can be made ly having a pieture posteard model and reproducing on a larger scale with colored paper. Sometimes erepe paper is used because it is more conveniently procured in necessary shades and gives a better effeet. Usually a pale blue paper covers the upper part of the foundation paper or pasteboard, and green for grass, or any other necessary color, on the lower part. On these are pasted houses, animals, people, etc.. in proper relation. Ifuch ean be tanght in making one of these pictures. Perspective, color harmony, form, ete., as well as the skill in wielding the scissors, and the ingenuity in acquiring and using the colored paper. I portion of a liscarded and torn colored lithograph may supply one shade, and an old envelope another. Peneil and eolor hox are not needed, and indeed. shonld not be used for this work. Many other forms of this work will suggest thenselves. Making chains or other ornaments for the ('histmas tree. Motifs for the decoration of a box or room. May laskets. candy boxes. ete. but probably one of the hest ways to use paper colting is to illustrite a story, nursery rhyme, ete. If it is undesirable to use scissors. the ohjects may he made by tearing off small pieces. Ifter a short time one can become puite skilful in this. 
A further elaboration of this work is making pastehoard models of honses, ete., which may be grouped to form villages, farms, ete. The method of constructing these is very simple. As many sides of onr honse ats posible are drawn on the pastelonard, and after cutting ont they are pasted together by means of a narrow edge, which is left heyond the outline for this purpose. Windows, ete. must be drawn, and in this work the use of pencil and color box is to be encouraged.

Another development is the construction of doll's fumiture or boxes, which may he covered with eretonne.

\section{CREPE PAPER WORK.}

There are great possibilities in this work and many beantiful things ean he mate. 'The softuess of the material makes it possible to make flowers which are very natural. The Dennison Mamfiaturing ('o. pmblishes a little book alled drt and Decoration in Demuison laner, ('repe and Tisme, which is full of directions of how to make flowers, lamp sharles, ete.. and the montlilies often print articles on rarions neses of it. ('repe palper repe is used ats al sulutitute for reed in wearing bakkets. and is also bised to decoriate or cover

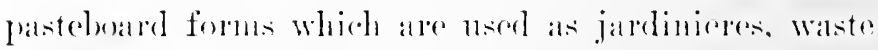

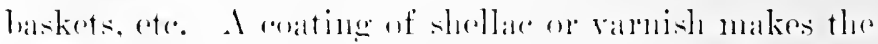

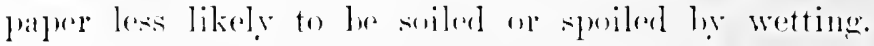

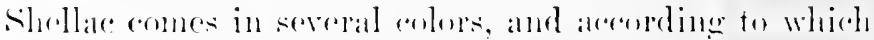

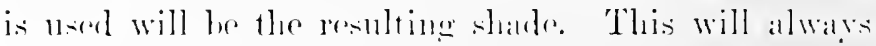
he dirrker than that of the papere nesed.

crepe palper rope can be benght in rarions sizer. 
but can he made by cutting a strip of paper the entire length of the roll and fastening one end to the small wheel of a sewing machine, one person holding the free end while another works the treadle, the paper being stretehed to its full capacity. The strips can also be made by hand. After two have been made they are twisted together in the opposite direction. Two ten inch strips, or half the width of the roll, will make a rope about lialf an inch in dianeter.

To make baskets, wires are covered with crepe paper and are used as spokes (see Basketry). Rope of $\frac{1}{5}$ or $\frac{1}{t}$ inch is used as the wearer.

\section{WALL PAPER.}

Wall paper may he used in many ways. Besides buying it by the roll a sample book can often be atequired from a dealer at the close of the season and will be found to contain many possibilities.

Paste.-The following makes an excellent paste: Dissolve a teasponful of almm in a cuart of hot water. When cold stir in flonr the consistency of thick cream, earefully beating up all the lumps. Stir in half at teatspoonful of powrlered resin. Ponr on the mixture a tea cup of hoiling water, stirring well. ('orer and keep in a cool phare. It anu be kept for a long time if the jars in which it is plited are tightly sealed while the paste is liot. Aunther rery good wily is to pome melterl paraftiu on top of the paste after it has halle ened. Whan needed for use take a portion : and soften 
it in warm water. I few dreps of ail of eloves or wintergreen will give at pleasant odor.

In pasting as in painting remember that it is the and of the bristle brush which is most effective in sprealing the paste and not the sides. 


\section{WOOD WORK.}

There is so much that may be done with wood that any selection would necessitate more space than can well be given to it here. In the first place the patient must be capable of being trusted with sharp toolsthat is he must not be actively suicidal, and while every case of depression is potentially suicidal, it has heen found that a great many of them can be trusted to work with sharp tools. Apparently the interest in the work canses at least a temporary subsidence of these ideals. The equipment for wood working may vary very unchl from a sloyd knife costing 1.5 cents to a hench and full equipment costing nearly one hundred dollars. Many serviceable and attractive articles: maly be made with the knife. Nearly a century agu I tical State IInspital had a whittling shop, where tows and other products of wood were mide. Knife work is tanght in our schools as a part of manual training. and several books have been written giving instruetion in this branch. ${ }^{1}$ In all of this work it is reeonnended that a working drawing be made before the

${ }_{1}$ Richardson. Elementary Knife Work, 25 cents. Air. : anced Knife Work, 25 cents.

Hammel, Wm. C. A. Elementary Knife Work. Arrancell Knife Work. Richmond, 1903. B. F. Johnson Publishing Co.

Larson. Elementary Sloyl and Whitling, 75 cents.

Goss. W. F. M. Bench Work in Wood. Ginn \& Co. 1ssi, $190 \%$. 
whittling is begun. If the patient does not care to make such a drawing it is proper to allow him to begin on the whittling which his fancy may dictate and later on to show him the adrantages to be derived from doing the work properly. Canes and paper cutters ean be made from sticks gathered during a walk through the woods. Plant labels, paper cutters, toys, wind toys, and a number of other things may be made from discarded boxes or other soft wood. The cleamess of wood and its delicate odor makes it a delightful material with which to work. Building paper board, such as Beaver board, is also an excellent material for boxes, doll houses, etc., and can often be combined with wood to make most attractive pieces of furniture. The Beaver $C^{\circ}$. at one time pullished a pamphlet giving directions for the manufacture of such articles. hut it has not been reprinted since the original edition was exhausted.

A coping saw is a liracket saw which ean be bought with 12 blades for 25 conts at any hardware store. With this any fret sawing may be done. although a foot power salw is more easily worked. Both of theser forms are excellent for traininge concentration of attention, the font power saw reperially, als ton much

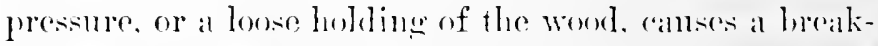
ing of the saw blalle, which arets ats an alarm and wakens the patient from his wool gathering.

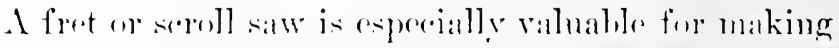

1 Jolmson Ben W. Coping Saw Work. Peoria, Manual Arts lress 120 (ख) 
puzzle pietures, and is probably used more for this purpose than any other. Various equipments may be purchased and a weekly entitled Inobbies is published in England specializing on this subject, although in it there are other matters of value.

The great objection to most designs which are made for fret sawing is that they are inartistic, and the articles made are dust catchers and have pre-eminently that quality which is best described as "ginger-bready." One should learn to know its use.

It is difficult to overestimate the value of wood working as a means of education, but unless the nurse has had special training in this branch there are many other forms of occupation which she can use better. If she has had manual training she will be at no loss for objects to make, and can construct for herself a bed tray. If her patient is better skilled than she perhaps he ean be indnced to make it for her as a nnark of his esteem. Even if she finds it necessary to cuploy the services of a carpenter she will find this tray a great ronvenience to her bed patient. Some prefer that it should have a rim abont three sides of about an inch and a half in height, but this adds to the thickness in packing and is not necessary.

The bed table can be made in a great variety of sizes. The one shown in Fig. 83 was intended for an sperial purpose and is 30 inches long by 12 inches wide. A more convenient size wonld be one that could be earried in a suitease, or about $11 \times 22$ inches. Thr simple form. shown in Fig. 34 as Bed Table I, can 
most easily be made of basswood or poplatr, and a mill bill for it would read as follows:

\section{Mill Bill for Bed Table I.}

$\left.\begin{array}{l}1 \text { piece } \frac{1}{2} \times 1+\times 2 \cdot 2 \\ 2 \text { pieces } \frac{1}{2} \times 1 \frac{1}{2} \times 1+\end{array}\right\}$ Top

$\left.\begin{array}{l}4 \text { pieces } \begin{array}{l}1 \\ 2\end{array} 2 \times 9 \\ 2 \text { pieces } \frac{1}{2} \times 2 \times 19\end{array}\right\}$ Legs

The two pieces $1.14 \times 14$ should be fastened across the ends of the largest piece. $\frac{1}{2} \times 1+\times 22$, as battens, to prevent warping and to give additional stability to the legs. Two of the pieces $\frac{1}{2} \times 2 \times 9$ should be fastened with a lap joint to the ends of each piece $\frac{1}{2} \times 2 \times 14$ at right angles to it. These form the legs and are fastened to the large piece with hinges so as to permit their being folded hack on it to be out of the way. A more finished looking jol can be made by the use of heavier material for the legs as in that ilhustrated in Fig. 33, where 1! inch stuff is used; but this adds weight. Or larger picees, $\frac{1}{2} \times 9 \times 14$, may be used to form logs and may lave a double ogee cut in the lower side for ornament. but these are not so good as the legs formed from three pieces.

\section{Bed Table II.}

$\Lambda$ better form of berl table is one which alu be inrlined to support a book. or palper on whirl the patient mar. wish to draw or write (Fig. : : 

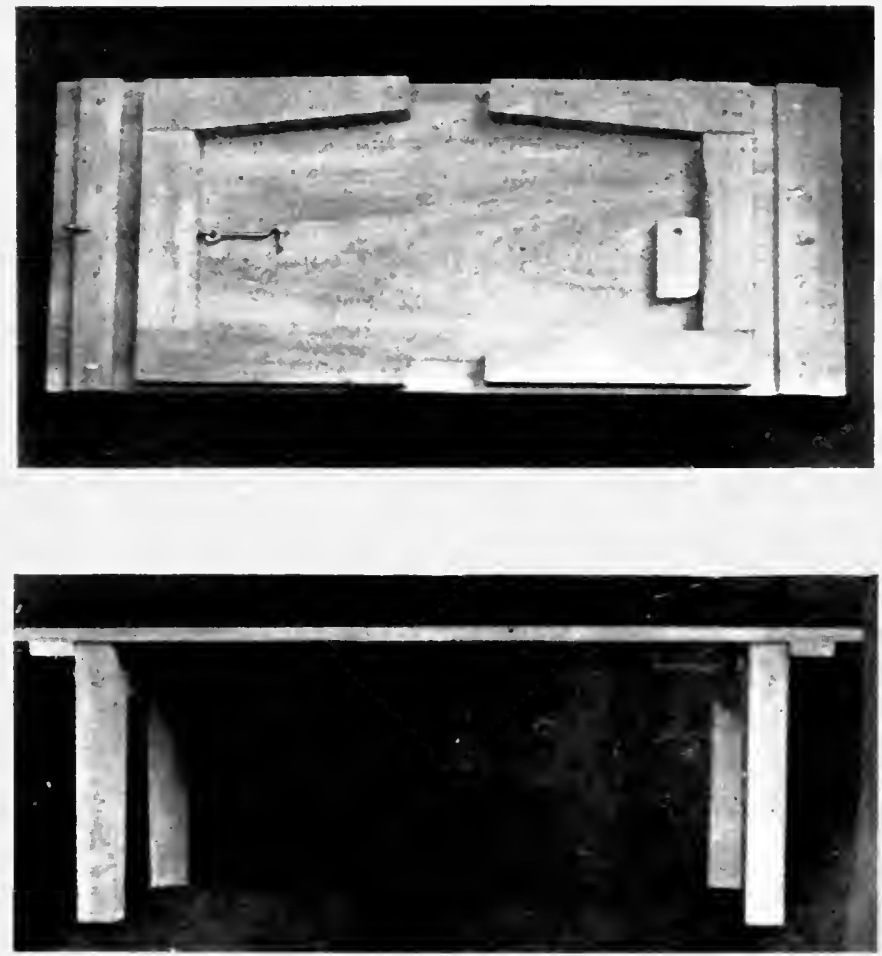

Fig. :i:- - Thed Table, I. 

WOOD WORK

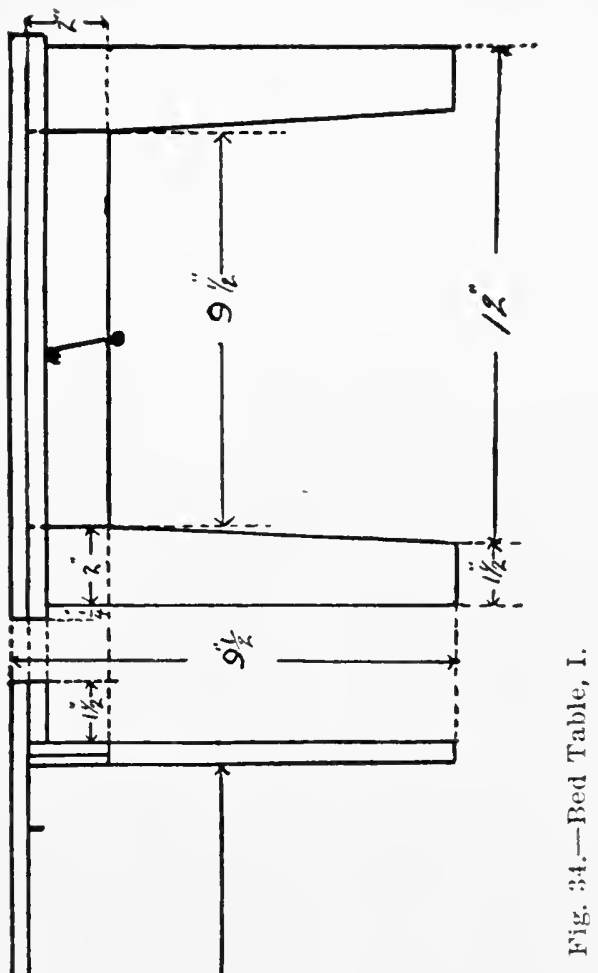


Mill Bill for Bed Talle II.

$\left.\begin{array}{l}1 \text { piece } \frac{1}{2} \times 132 \times 22 \\ 1 \text { piece } \frac{1}{2} \times 1 \times 22 \\ 2 \text { pieces } \frac{1}{2} \times 1 \frac{1}{2} \times 14\end{array}\right\}$ Top

$\left.\begin{array}{l}4 \text { pieces } \frac{1}{2} \times 2 \times 9 \\ 2 \text { pieces } \frac{1}{2} \times 2 \times 14\end{array}\right\}$ legs

$\left.\begin{array}{l}2 \text { pieces } \frac{1}{2} \times 1 \frac{1}{2} \times 8 \\ 1 \text { piece } \frac{1}{2} \times 1 \frac{1}{2} \times 19\end{array}\right\}$ Prop

$\left.\begin{array}{l}2 \text { pieces } \frac{1}{2} \times 1 \frac{1}{2} \times 14 \\ 2 \text { pieces } \frac{1}{2} \times 1 \frac{1}{2} \times 22 \\ 2 \text { pieces } \frac{1}{2} \times 3 \times 11\end{array}\right\}$ Frame

First making the top, the piece $\underset{2}{1} \times 1 \times 22$ is rounded on loth edges of one side and fastened along one side of the piece $? \times 1: 3 \times 2 \times 2$. to serve as a rest for the book or paper, the two pieces $\frac{1}{2} \times 1 ! 2 \times 1+$ being fastened across the end as battens. The lesis are made as for hed talle $\mathrm{T}$. The frame is next made ly entting six fulater-inch notehes one inch apart on the two

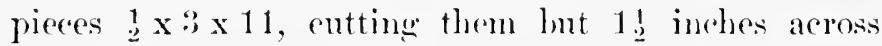
and the first being 1! inches from the end. The side of the noteh nearest to the end should he at right angles to the surfares and the othere side slope down to it. The me pieee shomkl he the converse of the other. The

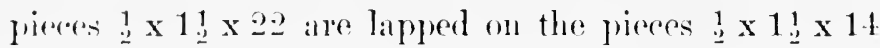
at right angles to form a rectangular frame with the noteled pieces lying inside or between the longitudinal 


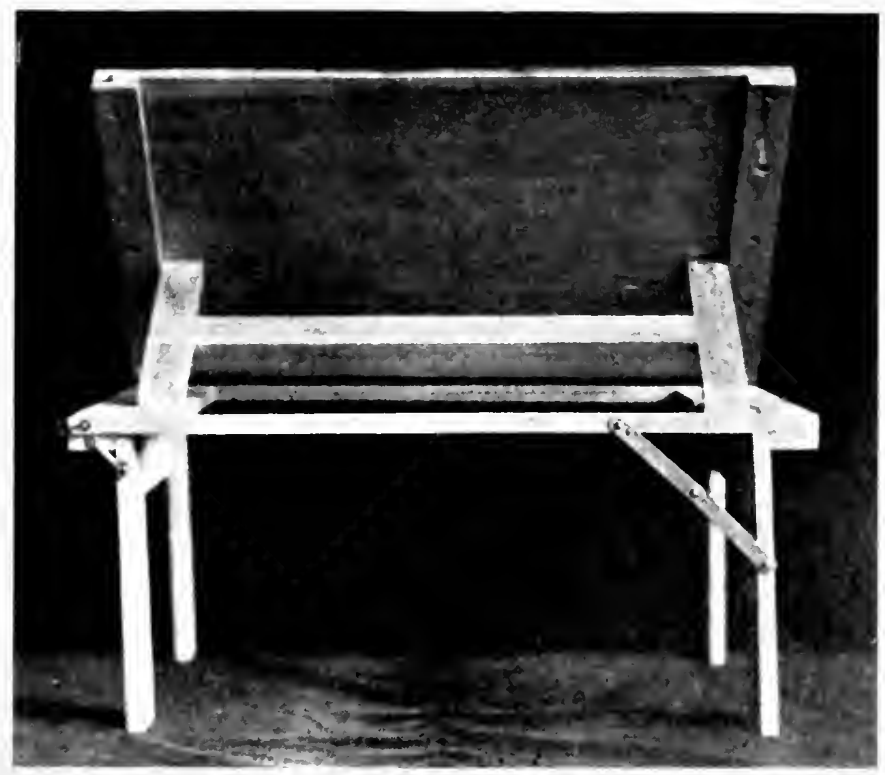

Fis. :3.- lied Tahle, ll. At the right the leg is hracol with a morlitied jack linife desk rest, on the left hy a hook. The smaller hook just above $i$ ' holds the fanme and the top together when folled.

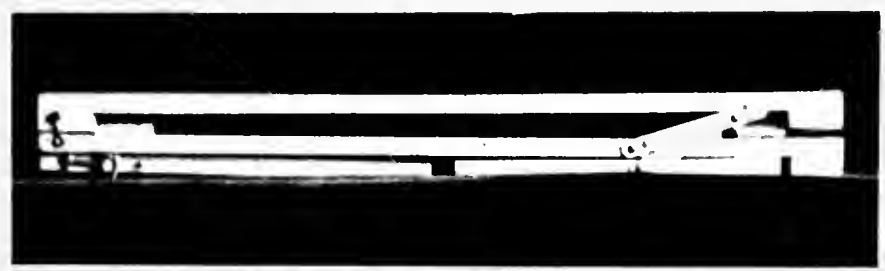

Fig. :36. The same tahle as Fig. : :5 resed. 

pieces. The prop is made by lapjointing the piece $\frac{1}{2} \times 1 \frac{1}{2} \times 19$ at the middle of the two pieces $\frac{1}{2} \times 1 \frac{1}{2} \times 8$, these being sharpened at the end, which is to fit into the notehes, and fastened to the under side of the top piece with hinges set six inches from the lower edge so that the prop will fall into the notehes as the top is raised. The top and frame are hinged together at the lower edge, and the legs hinged to the lower side of the frame elose to the end pieces to give stability. When folded this table oceupies a space of but $2 \times 14 \times 22$ inches and weighs about six pounds. Inooks of various sorts may be used to hold the legs in position, or a button, but the best arrangement is to saw off two jackknife desk slides abont three inches (when folded) as is shown in Fig. 35; or dolphin hinges may be used. It is diffienlt to arrange looks so that they will not slip, but the manner of applying them is shown in Figs. 33 and 35.

A very attractive bed table was made by a blind cabinet maker of the Baltimore Workshop for the Blind, who first made a frame with handles as for a rass-hottomed serving tray and in this fitted a wooden frame caned in oetagonal pattern (see page 154). The legs were formed by two T'shaped pieces of iron, $! \mathrm{x} !$ inch. fastened to the eaned frame and folding under it. The great alvantage of this tray is lightness, but it has the disadvantage of not having a that surface on which to work, and of having a mumber of crevices to harbor dirt. in ease ford should be spilt. This last. objection would appear to he rather theoretical than 


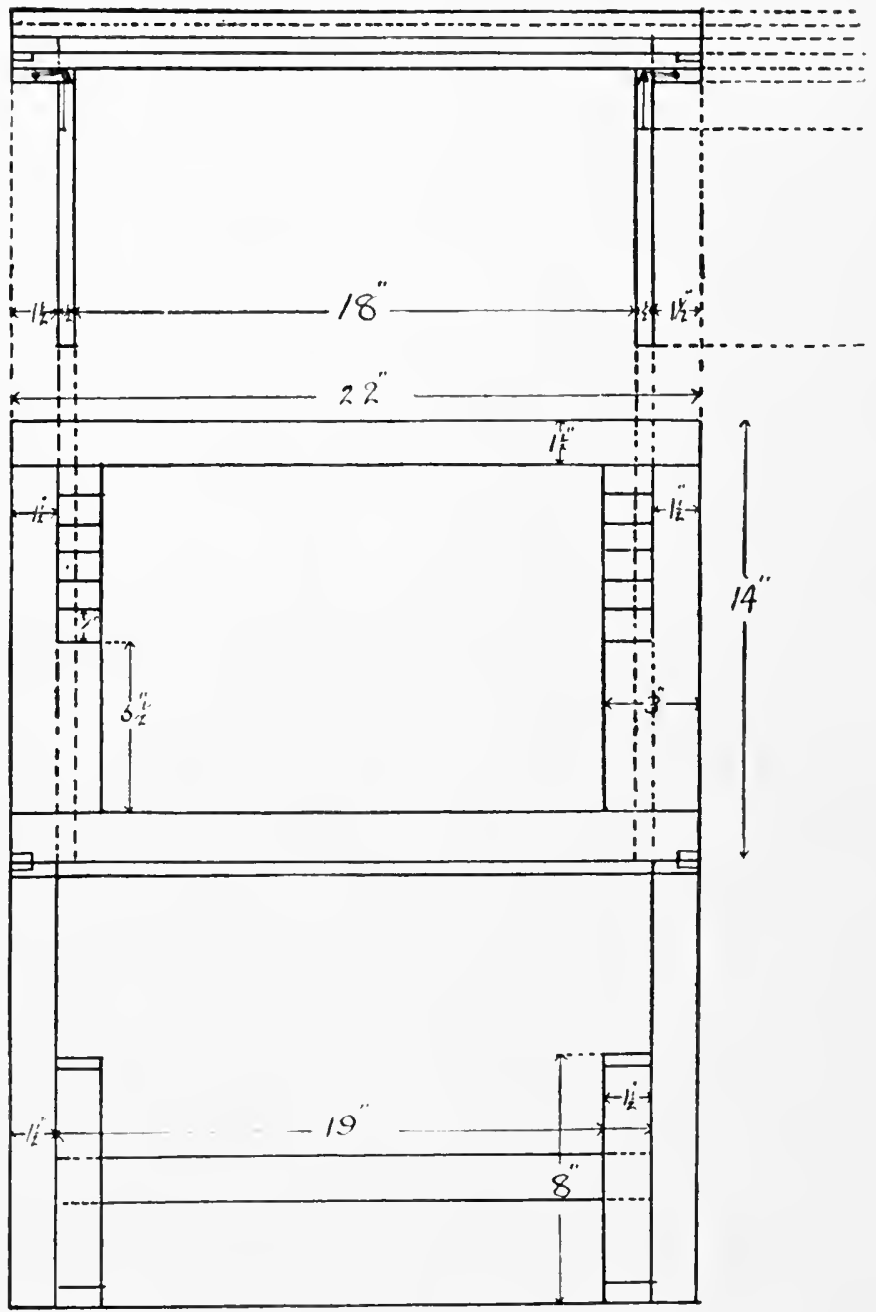

Fig. :7,-- Working lorawing of Bed Table, II. 


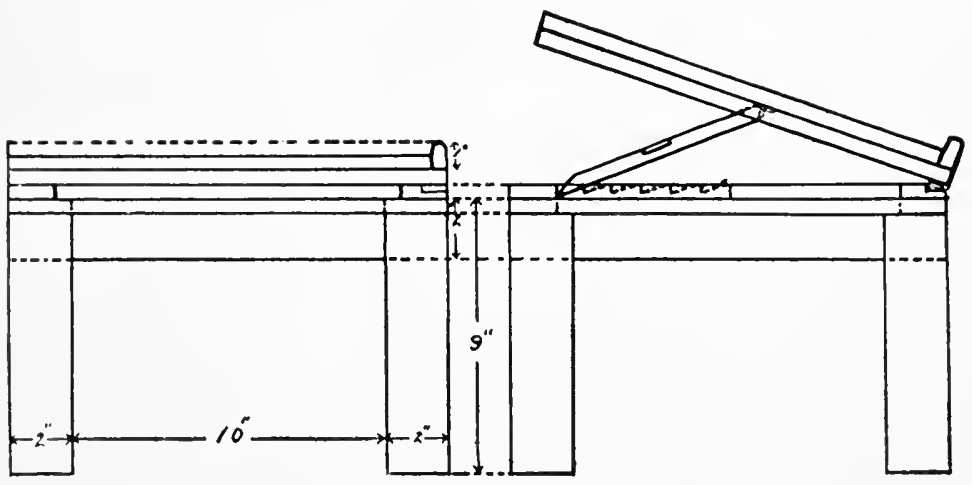

Fig. $37 \mathrm{~A}$.

practical, as cane-seated chairs have nerer been classed as dirt catchers. I bed tray adds greatly to the confort of the bed patient.

Directions and sngegestions for attractive and useful wooden articles are constantly appearing in the periodicals. These, with some book on the subject, shonld be consulted by the murse who is interested. 


\section{PICTURE PUZZLES.}

The solving of puzzle pictures which was so popular an amusement for eonvalescents in some of onr general hospitals a few years ago, is an excellent diversion, and the murse's arnentarium should inelude one or more of these. A number of patients are known to have been lelped to recovery ly the use of at scroll saw in making puzzles. Any picture ean be used, but the best are those which have distinct ontlines and are rather lrightly colored. Acoording as they are ent will their solving be dittieult or eas.y. The tirst step. however, is to momit our picture. Isually poptar or basswood of about one-righth inch thickness is used, but sometimes this is difticult to procure. Some of the largerer hardware supply houses sell what is ealled triple reneer which is an excellent sulstitute and indeed is prefered by sme puzzle makers. Old cast off cigar boxes may serve to make small puzzles. but if mo thin wood is procolrable we mist nise newsboard or some where form of palsteloard. Assmuing that we have heesu fortunate in serming the piece of thin poplar. or better. basswood, the picture is thoromghly pasted on the back and, after being laid on the worde is covered with

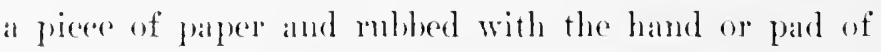
some sort to insure al close apposition between the wood and the pioture and to geet rid of any air lublubes. When this has beren done the word is turned oreer and 
a piece of paper is mounted on the back. This lessens the tendency to warp. The wood is then laid on a flat surface under pressure to prevent warping during the drying. When drying is completed we are ready to saw our picture with a fret or coping saw. The ordinary blades which are supplied for scroll sawing usually make quite a coarse ent, and what is known as a metal blade (No. 5) will do more satisfactory work. If we wish to make our puzzle an easy one we simply salw wayy lines from top to bottom and then across. The resulting irregular pieces having been cut with no relation to the picture will be found to be quite easily rearranged to form the picture. If we wish the puzzle to be diffienlt, we saw out according to the design, the saw following lines which indicate contrasts, such as that between the face and a hood, or between the white trouser and green grass, the olject being to elininate any bit of color on one piece which will give al clue to the piece which adjoins it.

It is usually more difficult to solve the puzale hy form rather than color clues. Sometimes it is possible to make forms of animals or objerts in the pieces which are sawn up after the first sawing has been done to eliminate the color clues. Practice is needed to reateh this point, however.

But if we cammot procure wood and have to use pasteboard we an still make very delightful and useful puzzles. The simplest way is by straight ants of soissors into irregular pieces. If the pasteboard is not too thick this can lo done very woll. We cint also cut in 
curves and follow the outlines of objects ats indicated above and produce a more interesting puzzle. It is just as necessary to mount a back on pasteboard to prevent warping, and we should he careful that the pastehoard is sufficiently thin to he cut with the availalus scissors. A eard entter may be used for this work in the hospital, and on this binder's board may be ant: but most honseholds do not possess one of these muless an amateur photographer is a member of it.

Pietures with a good deal of detail and somewhat ammsing in character often make most valual,le puzzles. hecanse they appeal more to the solver. One of the most difficult of these puzzles that I ever salw was matle from a Japanese print and ronsisted of about 200 pieces. The peculiar attitudes and unusual coloring really forced one to solve ly shape rather than color or design. Periodicals often contain pictures which make excellent puzzles when ent up, and their corers ale of especial value. 


\section{BASKETRY.}

Of the origin of basketry we know little. It is one of the oldest of handicrafts and possibly our aneestors. Id:mu and Eve, were the inventors. The Roman soldiers at the Conquest of Britain were astonished at the coracles of the Britons, which, as we all remember from the picture in our history books, were basket hoats covered with hides. Probably the earliest reference in history is to the ark of bulrushes in which Moses lay when found by Pharaolis daughter (Exodus 2, 10). Mr. George Wharton James, who is an anthority on Indian baskets, ${ }^{1}$ is of the opinion that baskets have developed from the net work which was made to protect gourds used to carry water across the desert, and so render them less liable to break. Nuch folk-lore and tradition has been woven into baskets which the Indian scuaws made, and ethonologists have studied them in order to preserve the history of a race that has become so analgamated with the Cancasian that it has to a latre degree lost its identity. The Indian used baskets for many purposes. Te had them in a sack-like form for carrying grain, jar-like for storing it. baskets in which to loil acoms ly means of liot stones drepped in the water. plaques for food. and. in fact, haskets for "reery enceivalile purpose. They were even noed in

1 James, George Wharton, Indian Basketry and How to Make Indian and Other Baskets, Thirl Edition. Pasadena, Cal., 1903. Irivately printed by the author. 
reremonies and often show the value placed on them by the maker by the bits of ornament added to them. such as wampum, feathers, beads, bits of silver, ete. Efforts have been made to preserve this art, for to sueh a point did the American Indian carry it. and many persons. hoth Indian and Caucasian, by collecting the best speeimens and by teaching have striven to bring this work back to the high point as shown by some of the older specimens. Even untrained Indians, however. still produce beautiful baskets, but oecasionally the desire for an exclusive design or color combination canses the production of something unattractive. Harriet Cushman Wilkie has reeorded that one squaw thought she hat achieved her ambition for an exelusive design when she offered for sale a beantifully fine white basket. with a border in the back stems of maiden hair ferms as follows:

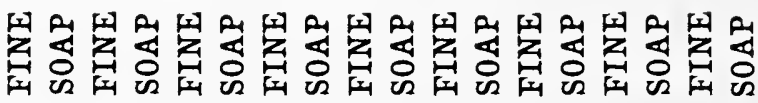

The Indian med any material that might he near at hand and wo have baskets made of willow, ruecal filue. falm, wood splints, barks, roots, grasses and stems. all of rilrions kinds.

Like the Indian we may make baskets of the material near at hand, althongh most of us prefer to hiy it ready prepared for weaving. There is opportunity for a basket maker to derelop some special material or method

Wilkie, Harriet Cushman. Ameriean Basketry. The Modern Priscilla, Vol. XVI, No. 4, June, 1902. 
of basket making, as has been done with long pine needles for eoil work, or with honersuchle vines.

The most common materials for baskets are reed, raffia, willow, wood splints, and rushes, althongh banhoo, straw, liusks, sweet and other kinds of grass, maiden-laair fern stems, honeysuckle, long pine needles, and crepe paper have been used.

Reed is made from rattan or cane, which is a vine growing, both wild and eultivated, in the East India Islands where there is an ammal rainfall of about 128 inches. It is said to grow as long as 500 feet. but 270 feet is said to be an arerage length. Ifter the vine has grown four years the single shoot that comes up from the seed is ent, and from this 300 shoots come ont. These are ent every rear, stripped of their leares and cut into convenient lengths for shipping and handling. The outer smooth bark is shaved off and forms the eane with which we are familiar in eane seated chairs. The inner part, or pith, is made into various sizes from 00 , which is alont the size of coarse thread, to 10 . which is about a half of an inch in dimmeter. It is to this part that we apply the name of reed. One of the great advantages of reed as a material for baskets is that we may leave our basket incomplete at any stage and cone latck and finish it at any time withont in any way spoiting onr hasket. Another advantage is that it onmes in pieces abrint 12 foet long. It dyes well and is one of the most anvenient of hasketry materials. Onr dependene upon it was shown at the ontbreak of the present Furopean War when, in consequence of the lawal 
demand and a cut off supply, it coming from Germany, the price in limited quantities rose 30 per ecut.

Raffia is the epidermal strips of one of the Palmacene, Raphia ruffia, which grows in Madagasear, and Raphia taedigera, which grows in Japan. It seens to be a longleafed grass, usually heing marketed about :30 inches long. It is used as binder twine in horticulture and by florists to tie up their plants. It dyes in beantiful shades, but must first be soaked in some mildly alkaline solution such as soapy water. With this material beautiful baskets closely resembling Indian baskets have been made. I have seen others made in poster or elintz designs which were most attractive.

IVillow is the most common basket material for commercial use. Botanically it is known as Salix, of which there are many varieties, and has a wide distribution. being usually cultivated in lowlands which ean be flooded. After the piece of willow which has been put in the earth has rooted, it is cut off. Numerous shoots are sent out which are allowed to grow until they are about 5 feet long, when they are cut. The cutting, however, must be done in the early spring, when the sap begins to run, or just before cold weather, though some willow growers do the cutting in August. These twigs are bundled and set in boiling water to bosen the batrk, which is peeled off ly passing the twig between two upriglit piees of metal. Which pull off the bark without seraping the twig. After hundling. the twigs are ready to be marketed and are sold at about if cents per pound. The disadvantage of this material for use 
by the amateur is that it requires a certain amount of preparation. For weavers the willow is usually split into three, a knife of special design with three radiating blades sometimes being used to start the splits, although an ordinary knife can be nsed. The splitting is completed with the finger or a speeially shaped piece of wood which forces apart the three picees. IIcre is where one realizes that practice makes perfect. These split pieces are then drawn under a knife set horizontally in a block so that it is a certain distance above the hoard over which the piece of willow is drawn. This makes them of a uniform thickness, and they are drawn between two upright knives to makes them of a uniform width. although the tapering which all willow shows camnot be entirely eliminated except by using very short pieces. A good basket maker takes adrantage of the tapering to make some beautiful effects. Besides the disadrantage of the necessary preparation for the amatemr. another is the necessity of finishing certain parts before laying the work aside. This is hecaluse the drying must take place uniformly. For example, in making a willow basket we mar make the lwttom, the sides, the horder, and the handle in separate operations. but we eannot stop in the midst of any one, or our basket will be mushapely. Willow bends more easily than reed and has a more pleasant feel in working, so that I prefer it.

llood splints were made ly the Tndians by shaving off thin. loroad strips of hickory. It the present time they are made he machinery firm several kinds of wood 
and form eontainers for many uses, among them being berry boxes, clothes baskets, ete. They may be dyed, and from them can be made very attraetive baskets.

Com hushs are said to form very beantiful baskets on aceount of their beautiful colors. They are usually split into a certain width and braided to form wearers. as it is not possible to form them into a hasket without some more rigid material as a support. They may also he used in coil work. ('it-tails or rushes may be used in the same way. Botanically this is Seripus laeustris. It should he gathered in .July, or before the "eat-tails" mature, and should be dried slowly.

Suect grass is usually bought braided. Botanically it is Znstera, one of a group of apuatic plants which grow in shallow bogs. So far as I know, it grows best in Maine. It also ean only be used as a weaver or for (oil work, as it is very fine and only about eight inches long.

Maiden-hair fern stem, which heautifies so many Indian balskets, caln be procured in most of our forests if we take the troulle to gather it. Its gathering would he an exeellent motive for a walk. It is said to be the must perfect hack known.

Itomeysurlile rines have been used and make very un11:1lal bakkets. It would seem that this material might he developed into a substitute for reed by boiling and stripping the latk as is done with willow. This and some othere of our common plants offer oplortmitios to the experinenters. Tomghness and length are the sper 


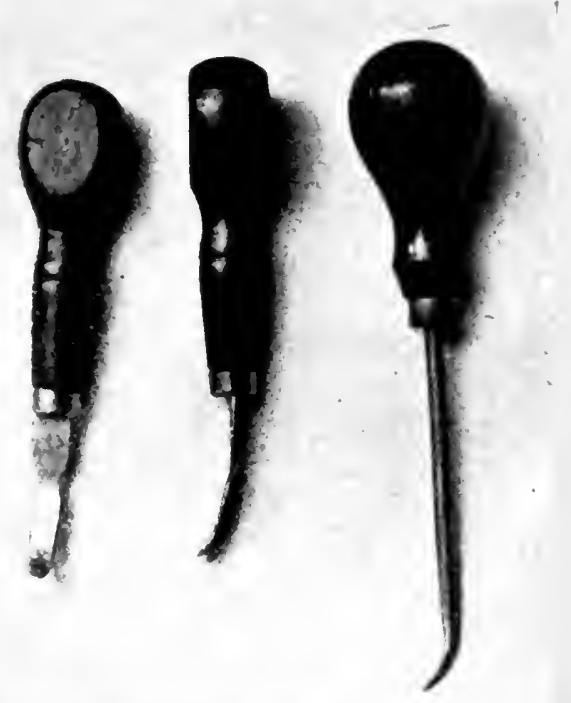

Fin. : P. Pasketry Toods. 


\section{,}


cially desirable qualities that basket material should possess.

In the following pages it is assumed that the material used is reed, as this requires less equipment than willow and is therefore the most convenient material for the private nurse to use. It can be purchased in small quantities at any of the educational supply stores.

In doing reed work it is necessary to have three, and preferably, six tools. These are, first, a pair of eutting pliers, either end or side, the latter being preferred by most hasket makers, to eut the reed. Scissor's will not reach to some parts of baskets where it is necessary to cut the reed. Second, a pair of round-nosed pliers to erush the reed when it is to be bent. Third, a carpenter's serateh or marking awl, which is used to split the reed or to make openings between reeds after it lials leen woven. Fourth, a speeially made tool (Fig. 35) to press the reeds together. This saves the finger's, is very convenient, and eosts little. It can be made from a scrateh aw by flattening it lack of the point and bending it over. or hy filing off the corners of a tiveinch screw driver and then hending it. This latst is probably the better tool. hut a hroad nut-pick will serve faliry well. The plate makes this more clear. Fifth. a knife will be foumd to be useful, as will also, sixth, a measure.

The nurse must moderstand that in the following directime she is given lut the neepsing rudiments of

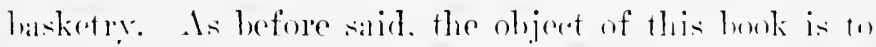
point the way only, and if a craft is to le followed 
out and developed it must be done ly reference to some of the many works on the subject. Is to the best hook on basketry, it is like Betser Gamp's friend Mrs. 'Arris. Personally; I prefer Tumer's ${ }^{1}$ The Basket Maker for heginners, as it seems to me to point out essential prin-iples most elearly. Marten 's² Tnexpensive Basketry is the best for the beginner in coil work. and has many grood suggestions as to oltaining materials. There are so many good hooks on the subject that almost anyone will give suffieient information to make its purchiase profitable.

Spokes are the coarser reeds used as a foundation around which the winders or weavers are woren.

The waring is almost invariably done from left to right.

A tub or bucket of water and a wet sponge or eloth should always be at hand to keep the reed moist. The reed should alwily be soaked mutil thoromghly wet before it is worked.

\section{BASES.}

In making a basket we must first hegin with the hase. These may he woren from the same material of whieh the balsket is made or may he of some other matepial, nimally word. Poplar is, perhips. nsed more than any other kind. lut hatsword and oak alre better looking. I priere of wood of the size and shape that it

1 Turner, Juther Wr. The Basket Maker. Worcester, Mass, The Daris Pows, 1!n!t, \$1.011.

SMarten, William S. Inexpensive Basketry Peoria, Illinois, The Manual Arts Press, gj rents. 
is desired to make the basket is sawed from quarter-inch stuff, and about the edge, about a quarter of an inch back from it are drilled holes the size of the spokes that are to be used. The number and distance apart will be governed by the size of reed used in the wearing. The spokes having been put in these holes, are pulled through on the bottom side until they project for two or more inches. With the round-nose pliers crush each spoke close to the base, bend it orer and pass it in front of the next two, and back of the third. After doing this all around the base, the ends are trimmed close. Some persons prefer to insert the spokes in the base by tipping them with glue, but it is preferable to use the above method, or to make a foot by weaving on as much as may be desired. 1 wooden hase is better than a reed base for waste baskets, jardinieres. or for any 'ontaliner which requires a closed bottom.

Reed or woren bottoms are preferable in most baskets. Taking the spokes we find their middle by donbling or measuring, and holding half the number that between the left forefinger and thmul, cross over them at right angles the remaining spokes. Taking a weaver in the right hand, place the end between the lower group of spokes and the left forefinger. then wind above the upper group and below the lower group until two complete circuits have been made. Continue the winding, going alternately above and below arch spoke mutil the dianeter is the size desired. It will he fomd at the completion of the first aircuit of winding of single spokes that the next cirenit will bring the winder alongside of 
the winder and not on the opposite side of the spoke. This may be overeome in sereral ways, first, by using a second winder at the completion of the first cirenit; second. ly using a half spoke so that the number of spokes is odd instead of eren; third, by skipping a spoke, which is permissible muly for a circuit or two, and lastly, by using the Japanese weave, which consists in passing the winder over two spokes and under one, producing a very pretty effect. Lsually in the directions for making the basket it is indicated which one of these methods is to be used.

IIaving completed the base we are ready to turn up the spokes to form the sides of the basket and mike what is called the upset. First, erush each spoke close to the wearing, using the romd-nosed pliers. turn them up and continne wearing. keeping the spokes in the position that we wish the sides to take. It is essential to remember that the spokes wive the shape to the basket, that the winder serves to give them strength merely. and any irmegularity of position of the spole will give an irregularity in the shilpe of the halsket. It is somertimes desired to make some solt of a finish before bewimning the side waving. Frepuently an arrow is marde (jage 11:2), ar triple wearinge or some other sperial werare is noed for a complete airenit or two. aftere wheh the simple wearing is need to form the sides.

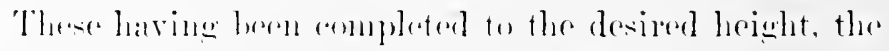

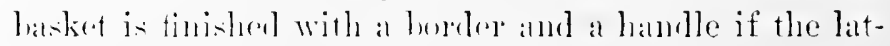
ter is dexirenl.

In malking the hater, instend of laying half of the 
spokes on top of the remainder and binding them together, we may split half of the spokes at the middle with the awl and push the remaining spokes throngh them; this, of course, makes the bottom flatter than is possible when the spokes are bound together. Willow bases are nsually made in this manner. In making the upset sometimes the spoke is ent off, and a spoke is inserted on one or both sides of it. This may be done for many reasons, but willow baskets are practically. always made in this way. The sides of the basket haring twice as many spokes as the base is so much the stronger, and the bottom is better because it is not crowded with spokes.

In making the sides of a basket there are a mumber of weares that we may use. Single weaving is most. commonly used and eonsists in plateing the weaver altemately hefore and behind the spokes.

Double wearing is done ly nsing two weavers at the same time and laying them together hefore and behind alternate spokes, the weavers lying side by side, patrallel. and not crossing each other.

Pairing is also worked with two wearers, one being placed hefore and the other behind the same spoke, and the weavers being crossed between the spokes.

Triple Twist, or wearing, is done on the same prinriple as pairing. lout with three wearers. These are plared bohind three eonsecutive spoles and. becinning with the left hand one. are hronght in sueeresion lofore two spokes and harek of the next, each loeing latid on top of the other two weavers. 
The Rope Twist is a variation of the foregoing principle, four weavers being used, each passing before three ronsentive spokes and behind the fourth, each being laid on top of the other three weavers. This same principle ean be applied to a larger number of warers, but is apt to give too loose an appearane to look well.

The Japanese Weave is malde with a single wearer, which goes before two spokes and bark of the third. This principle can also be extended to make a number of variations, but it must be remembered that the looser the weaving the weaker the basket.

Usually combinations of the above are made to give heanty to the baskets. Other materials than reed are also used such as braided straw, braided rushes, wood splints. ete.

\section{THE ARROW.}

The arrow is used like triple weaving to ornament the basket, and is only used to make a eomplete cireunference, for when repeated its beauty it lost. In making the arrow it is neressary to have three winders, each not less than two and a half times as long as the cir"muferemere. It is minally neessary to insert but two "xtra ones if the original winder is suffieiently long. These are inserted in separate interspaces, and the left hand winder is patsed under the other two hefore the next two spokes. Behind the third and out, repeating this to the hegiming. Then make the reverse lye passing the right hand winder before two spokes, helind one. and ont. The this with the other two winder. Then take the left hand winklere pare it ares the ofluen 
two, before two spokes, behind the next and out. Repeat this to the starting point, which it is well to mark with a pencil or thread. The extra winders are passed to the inside of the basket and ent off at the finish.

\section{BORDERS.}

1 basket repuires a horder to give it a neat finish, and there are a variety of these. The border often serves to strengthen the batsket. especially when they are male in what appears to be a complieated way and give what may he termed a heary finish to the hasket. Border's are always made with the spokes, which are nsmally hent down close to the weaving. and thus hold it close and so make the basket firm. Open borders, or lattice horders, as some call them. are not hent down close. and as a consenpence the batket is not so firm as it should lee, and presents a somewhat mifinished appearance.

The simplest open border is made by cutting off all of the spokes to a miform length of about three inches. hending each one down and pushing the end down beside the next spoke. This gives a sealloped effect.

A much better effect is obtained ly pushing the eur down beside the next but one spoke. This gives thr effect of orerlapping scallops.

Some of the open loorders can be made very attrantive by uning paired spokes which are left quite loug and inserted three or fom spokes berond their origin. This gives a bosely woren effect which mily be very attratetive, ats in Marleiral batkets.

The following border mal be matde either open w 
Mosed, the difference being that when made elosed all of the spokes are drawn tightly down to the wearing exeept the first three. which are left open to permit the threading of the last three throngh them. It is enstomary to bend these first three spokes orer pieces of waste reed of the same size as the spolke. In making this border alosed, the length of spoke alwore the woren side shonld he six inches. Take the first spoke and bemd it down at one and al half inches aluse the edge of the basket when it is to be mide open, or if the border is to be closed, crush all of the spokes close to the edge. then bend it over the piece of watse reed, palss it behind the serond spoke before the third and behimd the fourth, latring the end at the front of the hasket. Work each ryoke in the same waly until all are down but the last three. Take the first of these. bring it down belind the seremel and before the thirel. then threand it from behind mulder the first sproke med. Talke the serend spoke, loring it helind the rematining one and thread it be-

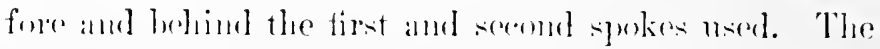
last spoke is threated behind and before and behind the firet three sukese, which will anmplete the pattern.

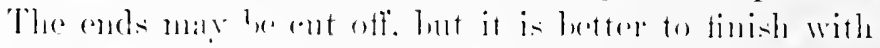

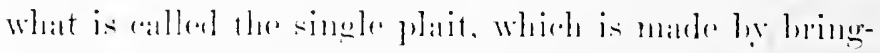

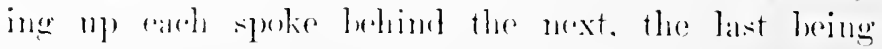
threatend nuthere the tirst. I ratriation is to work this

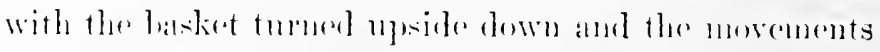
rererserel.

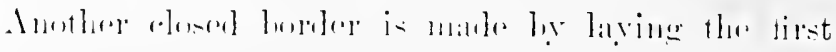

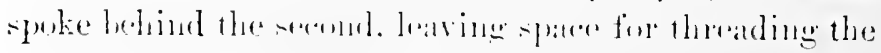


ends of the last spokes. Lay the second spoke behind the third. Pick up the first spoke and lay it before the third and behind the fourth. Take the third spoke (which is still upright), bring it down beside the first and behind the fourth, making one pair of ends turned down. The spokes forming these pairs must each in turn be kept side by side (the longer of the two being the right) and lield flat under the thumb until the next pair is turned down. Pick up the second spoke, bring it before the fourth and behind the fifth. Take the fourth (which is still upright), and bring it beside the second and behind the fifth. making the second pair. The longest of the first pair must now be brought before the fifth (which is still upright) and behind the sixth, the fifth being bronght down beside it as before. The shortest spolie of each pair is left to be eut off at the front when the work is finished, or to be threaded through to the inside and cut off there, making the edge still more substantial. Proced on this principle until all of the upright spokes lut one have been bronght down, and if correctly worked, there will always be two pairs of ends after the first pair is started, lut never more than two. Take the longer of the first pair and slip it behind and muler the first spoke. the last npright spoke heing hronght down beside it in the nsull waly, and passerl nuder the same spoke. Two pairs of ends will still be loft. Take the longest of the tirst pair, lay it in front of and beside the first spoke. bringing it out to the front muder the seend spoke. Tiake the longest end of the last pair. bring it in front of 
and beside the second, pass it under the third and the spoke in front of it. This border requires a spoke length of eight inehes and is sometimes called a rommureial border. The same kind of a border may be worked with three. four. five or more spokes as ealsily an with two. always remembering that the number of single spokes turned down at first determines the number of pairs. and that these must never vary until not one upright spoke is left. The ordinary border seen on a commercial basket is made with five spokes and is called a five plait. It requires a spoke length of ten inches, and is a very handsome and sulustantial border.

$A$ very simple horder is made by bringing the tirst spoke back of the second. in front of the third and fourth, and inside of the basket, repeating this for each spoke. The ends are hidden by passing orer the next. under the third, and learing, or cutting off. if necessilry.

Tarious other borders will be learlued at the bakketmaker progresses. but these are probably the must neeressary that she should know.

\section{HANDLES.}

Ilandles mare be mate in so many different walys that I prefor to give lut one which is ammonly lised on commereial baskets. is strong, and is generally inwerrectly made by the novice. Directions for making individual haskets nitually tell how the handles shomld he mades that details of other kinds are muecesary here. Handles are nsually made of a large size of reed or 
willow which should be specitied when ordering. A piece of this of the required length is sharpened at both ends, which are foreed into the basket beside two spokes which are directly opposite to each other. A long piece of reed is then inserted between the wearing leside the handle, passed around it three times and inserted between the wearing on the opposite side of the basket and on the opposite side of the handle, at a little distamee from it. It will be seen that the three turns about the hamdle divide it into five spaces, and these should he mide as equal as possible, the middle turn being "xactly in the middle of the handle. The reed is then "arried back alongside the first turns, through the wearing on the opposite sides, and so on, back and forth, mutil the entire handle is covered. the reed always lying alongside and never crossing the previons turn. It will also be noted that in passing through the weaving that on we side subsequent turns are lorought farther from the handle, while on the other they come nearer to it. which is the reason for the reed being passed through the wearing at a little distance from the handle at the ("ompletion of the first turn-that is, to allow spare for subsequent threadings of the reed. In light, ornanental baskets but three turns of the reed are sometimes nualu with excellent effect.

Direetions for making the baskets which follow are given in order that the nurse may have something detinite to go on mutil she arequires sone skill in bas-

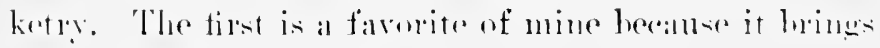
in al mulker of prineiples. 


\section{JAPANESE FLOWER BASKET.}

For spokes use 16 pieces No. 2. reed. each :i:2 inches long. For winders use No. 1 or No. 2 reed.

Arrange the spokes in fours to make a double cross retaining them in position by a winder alternating for four eomplete turns; then skip one set of four and continue winding for four complete turns. Repeat for four more turns, next divide the spokes with the winder into pairs. making a complete turn. Start a new winder which, alternating with the first, continue winding alwaly's keeping the inner winder allead of the outer, keeping at flat surface mutil the diameter meatsures three and a half inches. Then crush the spokes, tmon up sharply and make an arrow. ('ontinue winding. bending in gradually to make a curved surface or more abruptly to make a flatter one until at a heright of one and a half inclues the dianeter is two and a half inches, or fits a narrow tumbler. Finish off with an arrow.

The hamdle is made ly dividing the spelses into two gremps, each of which may he twisted or interweren in a valriety of walys.

Overlap the ends of these two groups and filsten with ratiia. Finish off he wappluge the handle with Xo. 1 reed or with the half round reed nised for this purpuse. The total height of the bilsket will be allont ten ineber.

\section{MADEIRA FRUIT BASKET.}

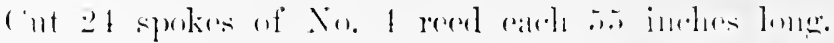
Find the middle of each. Split six of thene at the nid- 
dle and thread six other spokes through the split. making a eross. Treat the remainder in the same way. making another eross. Lay one cross on the other, so that their centres coincide, but the eight groups of spokes are equidistant and bind then together temporanily with ralfia or string. Bend a well-soaked piece of No. 2 reed in the middle and loop it orer the bottom group of six spokes, then with one strand weave under and orer until the loop is reached, then do the same with the other strand until three rows are woven. Sext separate the spokes into groups of three and continue the under and orer wearing until the strands end when roplace with Yo. 3 wearers and continue mutil the dianeter neasures six inches. Finish with an arrow. Mark off sixteen inehes on each spoke and see that they are thoroughly wet.

Take one group of three spokes and lace it under the next set to the right, over the second, under the third. over the fourth, under the fifth, and down through the arrow at the base of the fifth set to the sixteen inch mark. Repeat with each group of spokes. Great eare must be taken to keep the silles of the hasket eren. It may be plared aguinst the body and moulded with the arms.

Turn the basket bottom side up and weare four domble rows of plain waving with a Yo. :3 wearer. Wet the spolves anain and turn ealch group over the first set to the right, muler the serond, and turek the ends under the bottom, which should be anvex in shape.

For a landle take two 30 inch pieces of So. s reed. 
soak well, and insert on the outside of the basket down into the extra weaving on the underside and fasten in place with raffia. Using three weavers at a time make a six ply coil over the handle, catching into the laces work of the basket on the way orer and hack. There should be nine turns about the large reed, and it will $\mathrm{l}_{\mathrm{m}}$ more firmly attached to the basket if lont one long piese of reed is used, as is directed on page 146 .

\section{COIL WORK.}

Most of the Indian baskets were made by this methor eren though willow was used to make them. By means of a thread and needle, a rope or bundle of gralsses, or wher form of filmes, is coiled about itself to form the shape that it is desired to make the basket. The thread is some form of fibre which possesses tomghness and length, and is not eomposed of twisted short filhes suld als we nenally coneene thread to be. Calle and rattial alle the threads which are nsmally used for this work. the former for larege piecess and the latter for stuallor and unere ornamental forms. When raffia is noed a length of reed is usmally need for the coil. an it makes al firmer and more stalle basket than when a bumble of ratfia is

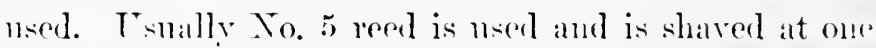
rud to form a point. Ifter being thoroughly soaked to make it pliable. it is wrapped with a strand of raftia

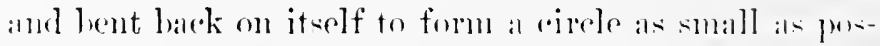
sille. or button. and is leld ly wrappinge or stitelhes of rattia. There alre quite a number of these stitches to 
which various names have been given, sometimes that of the tribe of which they are characteristic.

The figure-of-eight, or Navajo, stitch is perhaps the one which is used more frequently than any other, but is said to be an invention of some white woman and not an Indian stitch. As the name indieates, it consists in making a figure of eight with the thread about the two parts of the coil. In making a pattern with a color it numst be remembered that both parts of the coil will show this color.

The Lizy Squaw stitch is made by wrapping the raftia once about the outer coil, then once aromnd the outer and one below, making what may be termed a long and a short stiteh, which is continued. Here the color will also show on two coils. In using a color with the natural raffia the one which is not used is turned down and covered with the coil by the one that it is desired to show.

The IIopi stiteh is made on a soft coil after the first rircle, or hutton. has been made by thrusting the needle through the mper edge of the coil below, pulling the thread tight, making a wapping ahout the onter coil, sewing through the upper edge of the eoil helow: and so continning. When it is desired to add a color, the matural raftia stitches are made two or three farther than the place where it is desired to place the color. and these extra stitches are then covered orep with the (") lor.

The Kunt stiteh is mate he bringing the threated seedle w hetween the onter ail and the one helow to 
the left of the stitely which last bomd the coils together. Then aross over this stitch to the right, going down botween the coils to the right, then up. larek of the rrossed stitch, and orer so as to wap the outer roil again. Then walp the two roils, make the up stitch on the left, eross over, down between the two coils on the right, up, hack of the erosided stitell, and orer again. It is simply crossing the long stiteh of the lazy stitcli. With this, color shows on two eobls as with the lazy stitcli.

The IIarasupai stitch is the one most commonly nsed he the Indians. Mr. Tanmes states that fully four-fifths of the Indian haskets are made with it. and that both willow eoil and splints are used. After the button lias heen made, the thread is passed aromed the outer coil. and muder a wrap on the inner abil, an awl, or pricker. hering used to make the opening for it. colored splints are inserted at this point and passied to the ontside of the outer roil.

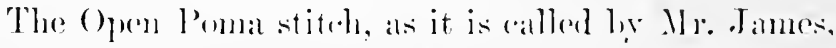

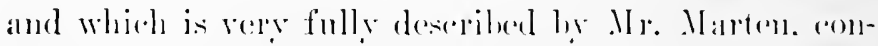
sists in making the waljs about the outer enil at some

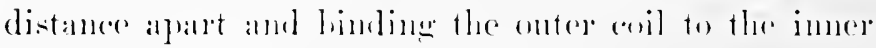

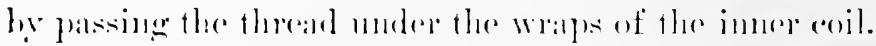

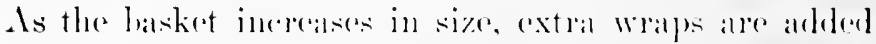

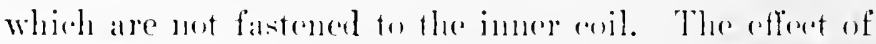
this is very attractive, as the stitelores make a speral effert. The little haskets mate of straw whele antalin

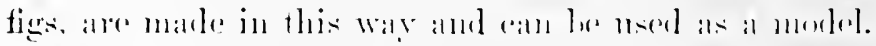
In all eoil work the finer the thread, the tiner the 
work. The Indians are said to have placed over fifty stitches to the inch. Some workers prefer to use the raffia dry and other wet, the last giving a firmer basket but an meven one if it is allowed to dry out between working hours. The needle used for rattia work is blunt pointed, has a large eve and is known as ling or Tapestry Needle No. 18.

Basketry is one of the most valuable occupations that we have, and is a most excellent way of training the attention. Yet it may be discontimed at any time so that the patient need not become fatigned. It edneates in form, color, and manipulation of hand, and may be of value in many other ways.

Firth. Cane Basliet Work, Part I. London, 1899, T. Upcott Gill; 65 cenis. Cane Basket Work, Part II. Same; 6j cents.

The Pine Needle Basket Book; 75 cents.

Knapp. Raphia and Reel Weaving; 50 cents.

Priscilla Baslietry; 25 cents.

Buck, Martin McCrae. Reed Baskets, their many uses and how to weave them. The craftsman, XXYII, sc, Oct., 1914.

Tinsley, L. R. Practical and Artistic Basketry; \$1.110.

Morse. Baslet Maling; How to Do It: 25 rents.

Hasluck. Basket Worli. Cassell \& Co.; 51) cents.

Blancharcl. The Baslietry Book. Chas. Suribner's Soms. $\$ 2.00$.

Turner, Luther Weston. The Basket Maker. New York. Atkinson, Mrent\%er \& co.: T.; ronts.

White, Mary. Ilow to Make IBaskets. New York, Houbleday, Page \& ro.: \$1.00. More Baskets and How to Halie Them. Same. $\$ 1.00$. 


\section{CHAIR CANING.}

Chairs bottomed with "ane in an ortagonal pattern are no longer so conmon as ther were in the severnties. although there has been a revival of this form in recent years. Woven cane lottoms are more generally used than this older hand work. It is need as an oecopation in some lospitals and as an industry for the blind. Is a form of weaving it has a distinct ralue.

The cane, as before stated (p. 13:3), is slaved from the outer part of rattan. It comes in rarying widths and may he procured at upholsterers' supply houses.

It must he thomghly soaked be fore being ned. The clate having been cleaned of the old ame. the worker sits before it on a low stool, or stimds before the chair, which is supported on a low bench. or lox. to a convenient height. The rentre munt first be fonnd and a length of cane is started at the front or laik k. being kept in the hole be a talpering pege of which the worker should later a number. It is rou straight areross to the

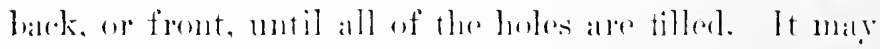

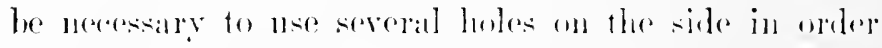
to till up the spalere, ats the front of a chair is widere

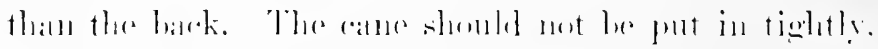

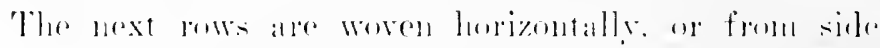

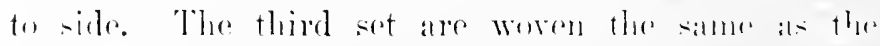
first, in the salne holes. and and tope of theme. The fourth set is again woren herizontally. were the upper 
vertical cane, and under the lower one. The upper vertical one always being pulled to the right. Te are now ready for the diagonal eanes. These are started from the front left comer to the back right and always pass under the vertical pairs and over the horizontal. The remaining diagonal eanes run from the front right hand corner to the back left, always passing over the rertical pair, and under the horizontal. The chair is finished with binding, which is heavier than the ordinary cane, and is laid over the holes and held in position by a piece of finer cane which is brought up through the hole, over the binding and down throngh the lole and across underneath to the next hole, although it may be done only at every other hole if preferred. The ends of cane are twisted twice under the next loop and bent sharply to keep them from slipping. 


\section{BOOKBINDING.}

Bookbinding is an exeellent araft for the mental or nervons convileseent becanse it is a "dereloping task," hy which I mean that the work hegins with simple operations whiell erandnally leerome more difficolt and aill for greater mental effort. In the final processe that of making the rasing, murele artistic allility may be

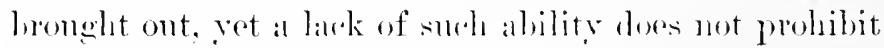

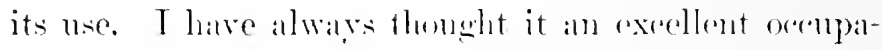
tion for women beranse they nore than mon pessess the allility of doing neat work, lout it is excellent for

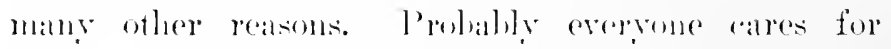
books. While some few persons may lave lint one or two of which they are foml. the albility to care for them

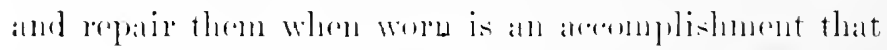
all fenple would like to latre. Thoklinding is not at all ditticult in its simplep forms.

The history of lowkbinding as given in the kincyelopedial Brittantea is mest interesting. Bimlinge on

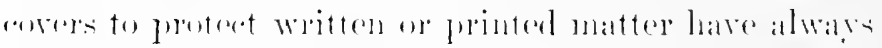
followed the shalpes of the mitterial on which the print-

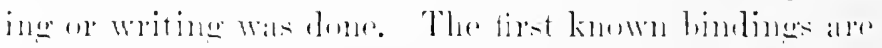

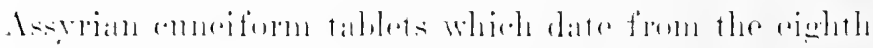

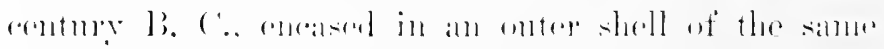

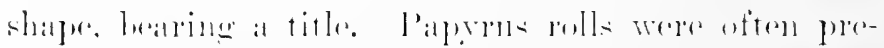

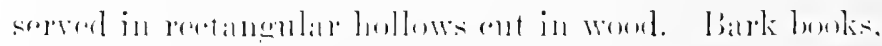
the next writing material, which is still noed he some 1,$1 ;$ 
uncultured nations, were folded back and forwards on themselves like the sides of a coneertina. In Ponpeii, in 1875 , were found diptychs ( $\mathrm{i}=\mathrm{two}$, and ptisso=to fold) of wood hollowed on the inner sides, filled with blackened wax, and hinged together at the back with leather thongs. An orihon is a seroll written on one side and so folded that the folds come between the columns. These folds were fastened together along one fold, usually by "stabbing." This forms a link between the roll and the book as we know it. Stabbing is the earliest method of binding and also the most amatemrish. Vellum was next used in book making, and in the tifth century several sheets, four or more, folded once, were stitched through the back. Next these were fistened ly the threads about a strong strip of leather or vellum lield at right angles to the line of the backs. This is the same method of hinding that is used to-day for flexible backs. It was soon found that these backs needed protection, so strips of leather were fistened over them. The vellum leaves eurled so much that wooden boards were fastened to ealch side, the loose ends of the back strips being fastened to the boards which hinged upon them, and the protecting strip of leather at the back was drawn orer the boards far enongh to coser the hinge. This was the mediarral 'half linding.' 'The boands were mslally' kept togerther ly a clasp in frout. The next step was that

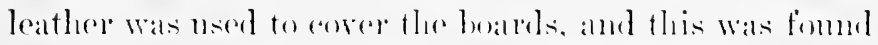
to give opportunity for derolation. They were limt "blind" stamped-that is, withont gold leat-and the 
tools with which this was done were ent intaglio, so giving a cameo form to the impression. Later binding became more elaborate, gold, silver, enamels, silk, embroidery, and other materials being used to enrieh and decorate the books. In the sixtecntle century pasteboard was used in platee of wood for the sides. thus deereasing the weight. Cold tooling on leather abo was invented and ly its use most artistic bindings have been made. Mr. Cobden Sanderion, Miss Prideanx, and Miss Mecoil are probably the hest known of moderu binders, and it will he noted that two of these three are women. Frequently omaments of different colored leather are inlaid in bindings, giving a very beantiful effect.

At the present time nost looks are bound by machinery, hut the steps are priatically the same as in hand binding. exoepting that of ataing. These are:

First. folding the shects which form the signatures. so called from the sign plaked on the fromt palee of ratch to guide the hinder.

Second. gathering these in propere order.

Third. sawinge the bareks to matre platers forl the stitches.

Fourth, stitrhing the signatures togethere.

Fifth. whoring the hark.

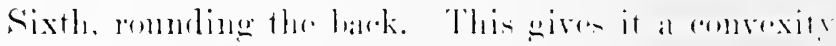
which helps to presorve jts shape. When it is mot llome

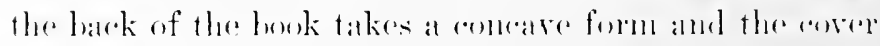
does mot tit se well. 
Seventh, backing. or putting on the piece of fabric which reinforees the back and forms the hinge.

Eighth, casing, or putting on what we call the cover. It is here that the difference between hand binding and machine binding is marked. In the former the cover is made on the book, in the latter it is made separately and placed on the book. As a matter of fact, at the present time only very large books or those hound by derotees of the craft are "hound," all commereial bindings being "eased." The last is more casily done and concerns us here as it requires muth less skill.

\section{PAMPHLET BINDING.}

By pamphlet binding we mean the binding of a single rignature, no matter of how many pages it may conwist. It is now unally done by a matehine known ats a wire stiteher which holds the sheets together by means of one or more pieces of wire like staples. When it is done by hand. linen thread is used (linders' thread (omes in a mumber of sizes) and the stitching is done ats follows: IIolding the folded sheets in the left hand, the threaded needle (a No. 1 sharp) is passed thromgh the sherets at the middle of the fold until about three inches of the thread remain. The nestle is then patserd thengh the fold in the opposite clirection at at point alkent laalf way betwern the erentre and the edgere, and in the opunite direstion at al similar point on the where side of the entre. It is then passed thromeh the central hele, conting ont on the oppesite side of the long stitch, the two ends then being tied over the longr 
stitch and the ends trimmed off. It simplifies the process to make the first and second stitches together, by one morement, ly bending the folded sheets at a point half between where it is desired to place the two.

Stallbed binding is seldom used. als a book so bound does not open well. It is only used when single sheets are to be homd or when an odd effect is desired. Here the sheets are placed together and stiteleses or metal fasteners are passed through then at the left side, so linding them together. Tape or thongs may be used. and are passed in and out and orep the ends when a ruaint effect is desired.

\section{SCRAP BOOK.}

A serap book is always useful and can be used by the murse to hold her colleretion of ratches and puzzhes or

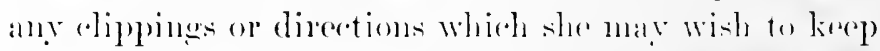
as orecopation motes. It can be mald withent an!" sper-

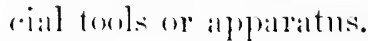

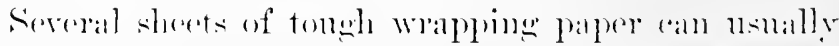

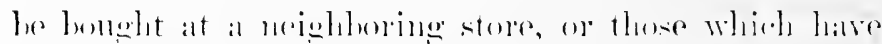

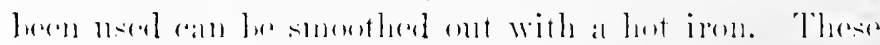

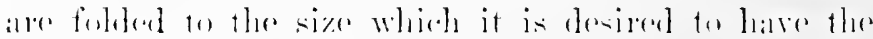
]

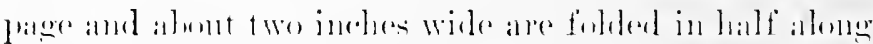

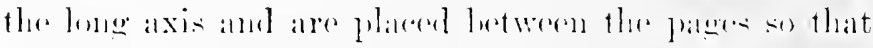
the fold eriberiles with the folld of the halek of the sig-

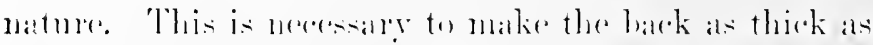
the palges will le when the elippinges atre pristed in it. When the signatures have all been frepared we alre 
ready to stitch them together. Sitting at a table with the left side towards it, open a signature in the middle and place the fold near the edge of the table, holding it in position with the left hand. This gives a hand on each side of the fold. With the right hand pass a threaded needle through the fold about one or two inches from the end, pulling it through with the left. With the left hand thrust the needle back again at a point about two inches from where the first stitch was made. We are now ready for our "fiddle strings" which may be of soft string or tape two or three inches longer than the thickness of the book. One of these is laid next to the thread and the needle passed back to the inside of the signature, elose to the other side of the tape or string, although when the latter is used some prefer to pass the needle through the same hole by which it has passed out. The number of fiddle strings used depends on the size of the book, but two should alwars be used. Ifter they have been placed about three inches apart. the threal is brought out about one or two inches from the end of the signature, another signature is plated on top of it and is treated in the same way, the stitrbing heing done in the opposite direction. When the therad is finally bronght ont alowe the starting point the two therals ale tiod with a spluale knot. We are now ready to stitrol another signature which is laid on the second

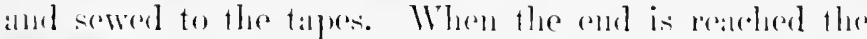
thread is bromelet down botwerom the first and second

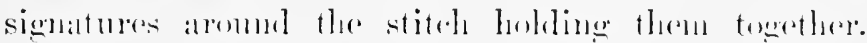

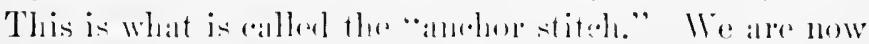


rady to sew on another signature, or if but three are to be used it is fastened off by making two half hitehes about the stitch between the first and second signatures. While doing this sewing it is necessary to keep the signatures in such position that their edges will be even. This can be done more easily if the signatures are "lamped together before being stitehed. the points where the needle is to be passed marked and then sawed through the folded sheets. This is best done with at back saw, but a coping or other fine toothed saw can be used. While sawing is a convenience, it is not necessary in making the loosely bound book on which we are engaged.

After we have stitched the signatures together, the back-that is, the folded edges where we have done our stitching-is smeared with glue and a piece of cheesecloth three or four inches wider than the hack of the book. and from one to three inches shorter. is placoul on it so that it is in the middle of the bark and the projecting edges are even. More glue is applied orel. it and the whole back is then covered with a piece of waste paper" ant its exact size. This prevents the bark of the case from sticking to the book and forms a thexible back.

We are mow ready to make the case. Two pieres of pasteloand are rut which should he a half inch longer than the page of the book and of the same width. A piere of waste papere of the salme leneth as the palsteforard and the wilth of the baek is also made reaty on line the hack. The material which is to lor noed for the 
rover is next prepared. Let us suppose it to be a piece of chintz. This is cut three inches longer than the length of the pasteboard, and three inches wider than twice the width of the pasteboard plus the width of the back plus a half an inch. It will be noted that the width of our chintz is greater than its length. The paper lining of the back is now corered with paste or thin glue and placed exactly in the middle of the chintz and smoothed down. The pasteboards are then pasted and placed one to the right and the other to the left of the paper strip and a quarter of an inch from it. Care must be taken to have the top and bottom edges of these three pieces on the same straight lines. With scissors make a straight cut, eutting off the corners of the rhintz at an angle of forty-five degrees, at an eighth of an inch from the corners of the pasteboard. Paste is now applied to the top of the three pieces and the npper edge of the ehintz turned over and smoothed down. The lower edge is pasted down in the same way and then the two sides. Before turning over the latter the folded portions are pressed together, and in this way the mitre is made neatly. To filsten the book in the calse. they are placed together and laid on the talle, one side is raised. the page under it is covered with paste and the side is brought over it so that its edges ance each at puilrter of an inch from these of the page. The beok is turned over and the other silde is treated in the same way. With the finger-nail press down the chintz along the edge of the balck. It is this part that forms the linger. The look in now ready to 
be placed under some form of pressure for twenty-four hours to dry although a longer period is better to allow proper "seasoning,"

If paper is used for covering, it should be pasted all over and the back lining and pasteboard sides placed on it. Care should be taken to select a paper of tough quality. Some of the hetter wall papers are excellent. If binders' muslin is nsed it camot be pasted, but must be glued. Experience alone an tell the proper consisteney of the glue. If it is too thick we eamuot work rapidly enough, and if too thin the muslin will blister or lose its gloss.

Press boards are hoards with a metal edge projeeting about an eighth of an inch. which is plared so as to press in the muslin between the back and the side. so as to form a neat looking hinge. They are oniy neessary when binding is to be taken up extensively. I"nder the same ciremustances a sewing bench is a great convenience, and is not expensive. If a serap brok is made as above directed and exantination is made of the various books which pass muder the mures's hambs she will have suffieient knowledge to repair hooks and make loose bindings. If she desires to derelop the araft it will he necessary to take some lessons or to stmdy some of the miny hooks on the subject. To me who "is handy at picking up things" a visit to a bindery will be helpful.

\section{lieforences:}

Bailey, 11. 'T. Bonlilet Making; 75 ents.

Bean, Florence 0 . Bookbinding for Beginners; \$1.25. 
Cockerell, Douglas. Bookbinding and the Care of Books. New York, Appleton; \$1.25.

Hasluck. Bookbinding; 50 cents.

Freeman, S. T. A Syllabus of Elementary Bookbinding ('Teachers' College, Columbia); 30 cents. 


\section{COLLECTING.}

The word collecting may bring up different emotions in different individuals aceording as to what their conception of the word may be. To the housewife-mother' who only knows that her boy's poekets lulge with miscellaneous objects whose value she camnot appreciate. and that each dusting day she is obliged to elear up a lot of "truek," the word collecting brings up disgnst or anger. To the experienced person who knows that each olject has its story of how it was aequired, where it was made, ly what sort of people. ete., the word can only lring up enthusiasm or joy. The nere wathering together of artieles is not collecting in its higher meaning, and such an oceupation should be discentraged. pren in millionaires. In collecting. an objeret should serves as a text or as a foems fore all of the knowlentere that it is

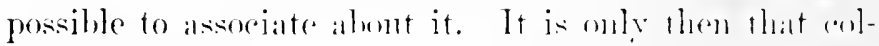
leeting heeromes of value. The hallit of investiention which can be incoldeated in this way will broaten the individual's intellectual horizon and increate his mental powers.

The choien of what is to be enllected is compantratively inmaterial. Stones. flowers, leaves. stanuss. "ups.

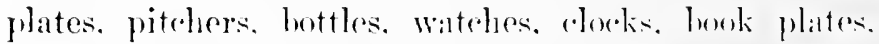
dolls. firehareks. books. engravings. pietures. atc.. have

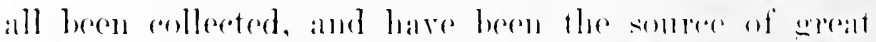
pleasure and profit to the collecetor and allow to these 
who have been privileged to go orer such collections, especially when the owner has unbosomed himself and told all that there was to tell about the various pieces.

The choice of a collection will depend on the patient's taste, what arouses his interest. the state of his pocketbook, and also on the interest and co-operation of the nurse, who ean do everything to stimnlate or discourage the patient.

Stamp Collecting.-I have always recommended stamp collecting to nurses as a hobby for several reasons. First. it is compact and will not take up much room. and if she does private work she will necessarily have to live much in her trunk. Second, it is probably the most interesting form of collecting because so much of romane. historry geography; etc., is associated with these bits of paper. One of the most delightful talks I ever heard was by $\mathrm{ITr}$. IT. Dwight Burroughs, ${ }^{1}$ who told us stories about rarious stamps which he shorred. Nost of these stories were history and therefore more interesting. Stamp collecting teaches us to observe things closely and detect small differences in them. It also teaches us to be neat, orderly and systematie. It has the further advantage of being profitable if persisted in long enough. as alnost all stamps increase in value ats their age increases.

I number of books are published which give direetions to beginners in stamp collecting. and it is well

1 Burroughs, W. Dwight. The Wonderland of Stamps. F. 1. Stokes Co.: \$1.5n. This is writlen especially for children, mit is interesting even to experienced collectors. 
to get one of these. An hour or so with an experieneed collector will probably be ruite as profitable, but it is well to have a book for reference. It is also well to sulscribe to a special periodical or one which contains a philatelie department, as in this way only can one keep up with the changes, new issues, ete, which oeenr. Certain stimp dealers sell a small collection with albmu and other necessary things, which may be a good way of beginning. It is much more sporting, however, to accuire one's stamps otherwise than ly purchase. Stealing is, of course. barred. lunt one can ask for the stamp on a letter or packige and usually get it. The uncertainty of the reply adds to the sportiveness of the crenpation. Sometimes we may fund a person with a foreign correspondenee who is willing to save the stamps for us. and we may have a delightuful time sorting over a lacket of these. A maiss of old letter's may prove to he a gold mine of interesting specimens. If none of these suntres are araibable to the young colleretors. I would advise the purehase of one of the "communem"

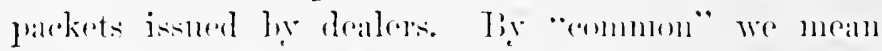

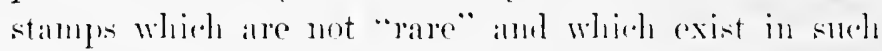
quantities that they have little value. There are momally.

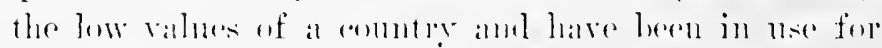

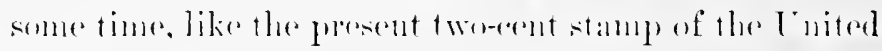

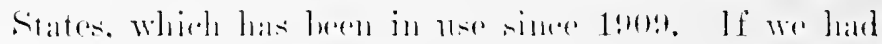
at priantity of these stamper to lowk were we would tind

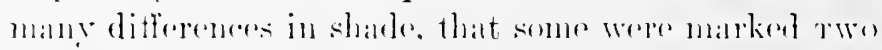

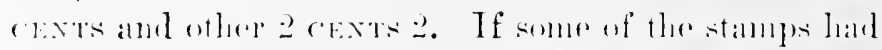

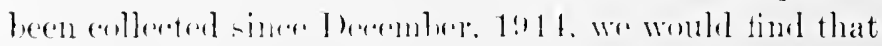


the perforations of these are larger and there are fewer of them. Still others have no perforation, others are perforated only at the sides, others only at the ends, others have only two long and broad perforations at the side. An expert could point out many other points. sneh as a differenee in watermarks, so that even a conlmon two-cent stamp has interest. In additional fact is that it bears the likeness of Washington, and it will be found that the stamp of a country which is in most "ommon use always bears the likeness of its most popular hero. A stamp of Brazil, besides bearing the smallest engraved portrait of Washington, has portraits of other Pan-Imerican heroes, such as Bolivar, O'Higgins, Jose Bonifacio, Hidalgo and San Martin.

1 stamp known as the $\mathrm{O}^{\prime}$ Connell stamp was issued ly one O'Connell, Postmaster of New Brunswick, bearing his likeness, and was promptly suppressed because it did not hear the likeness of Queen Tietoria. Copies of this stanp are so rare that they are ralued at one lundred and fifty dollars. I similar stamp was issued during the Boer War (190:3) and bears the likeness of Sir Baden Powell, who therehy incurred the displeasure of his sorereign.

A rare stamp, on the original enver (envelope) lats a areater vahue than one detardhed hecaluse then there ean le little question as to it. genuineness. hut ordinally stamps ane soaked from the paper on which they have been placed. This in itself mily prove a pleasant aml restful corpupation. Some stamps alre printed with ink which dissolves in water and so spoils the stamp, sneh 
as the Enited States Protage Doues. Wetriuge does no stamp any good. and I have fommd that when a stamp is on thick or ordinary paper the best plan is to float. it on water fare np. It first the paper will corl up. but as the different strata of the paper absorb water it will lie flat and later may rorl down. When lying flat

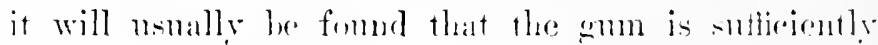
moist to slip off the stamp. Which is thes ]aid fared down to dere. Tweezers. eperially those with lowald end: marle for the purpose, are of great assistames iu handling the stanups. If the paper on the harek of the stamp is thin. sureh as Tapanese palper. it had hetter be laid bark down on wot heotting paper. The oljeret is to keep some of the original gmm ("o.e.") on the stamp. as it is therely more perfort. The majority of stamp dealers will buy eron ordinary stamps in plantitios if

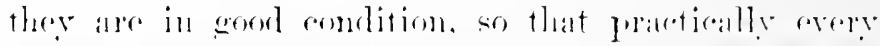

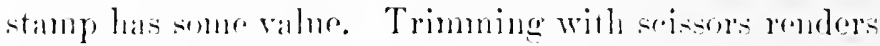
a stamp valuedess.

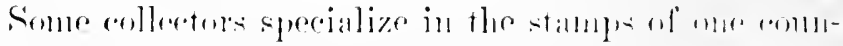

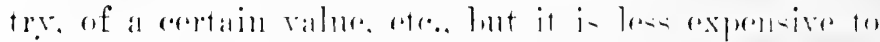

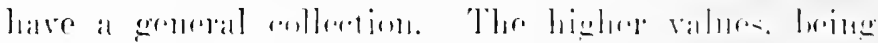

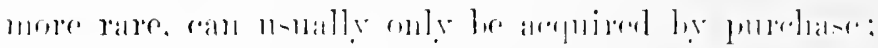

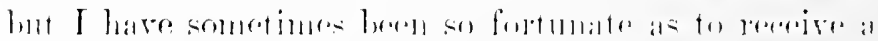

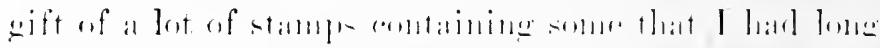

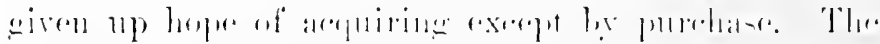

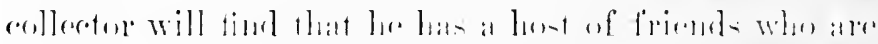

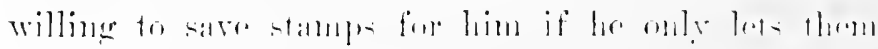
know that ho has this hollies.

Book collecting may lw male rery entortainimg by 
frequenting old book stores or auctions. For those who camnot attend book sales the dealers have a plan by which they receive bids sent by mail. I have found this a delightful occupation. The sales catalognes are accurate in giving the condition of the book, whether it is shaken, broken. foxed, ete, and also gives information as to editions, etc. which is of value to the book lover. I have always found these dealer's honorable in all their dealings, at times giving me a look at a lower price than I have bid, and I have never had to complain that their description of a book was inaceurate. by buying books in this way one ean lnild up a library at comparatively small cost. There is usually a charge, sulscription, so to speak, for the sales caltalognes, lut they are quite wortl their cost to the kook lover. I will he glad to give the manes of these dealers to myome interested.

It is possible to extend our list of collectible objects to wreat length, but it would be meless. No matter what it is that excites our patient's interest, if he can be indured to study about it and associated subjects, he shomld be encouraged to continue collecting.

The value of a hollyy to anyone ats a saforty-valve for

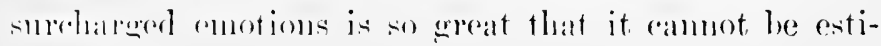
mained.

\section{liceforenes:}

Armstrong. Douglas H. Joys' Book of Stamp Collecting. F. A. Stolies, \$1.75.

Barler, 1)r. Elwin Allere (Curator of a Muselum) American Glassware; Old and Now. 
Burgess, F. W. (Collectors' Series). Chats on Household Curios; $\$ 2.00 ; 94$ illustrations, drawings and photographs. Describes interesting mementos of past generations with their original uses-among them fireirons and firebacks, rush lights, leather bottles, scratchbacks, spinning-wheels, cloclis, watches, chests, toys, relics of sport, etc. Besides of interest to collectors, throws much light on the domestic habits of our ancestors.

Burgess, F. W. (Collectors' Series). Chats on Old Copper and Brass; $\$ 2.00$. Informal style; covers fascinating field. Objects of use and ornament made from copper, its alloys, brass and bronze. The earlier prehistoric and Greek or Roman examples described are largely in museums, but a wealth of curios and artistic pieces can be secured hy the most modest collector who heeds the author's suggestions. complete with index and glossary.

Carleton, Emma. All About Bottles. The House Beautiful, X, 101; July, 1901.

Church, Nargaret. Some Old Bed Coverings (Quilting). The House Beautiful, X, 353; November. 1901.

Conway, Sir Martin (late Slade Prof. Fine Arts, University of Cambridge). The Sport of Collecting; $\$ 2.00$. By an enthusiast of world-wide experience. Old Masters, Italy; Pottery (and Mountain Climbing) Peru; Egypt, Japan, India, Thibet. Dr. Bode, famous art critic, vouches for authenticity of information. A most interesting book.

Blake, J. P. \& A. E. Reveirs-IJopkins. Little Boolis About Old Furniture; each, \$1.00. (Fully illustrated, Frederick A. Stolies Co.)

Kunz, Geo, Frederick. The Curious Lore of Precious Stones. J. H. Lippincott Co., Phila., 191t; \$5.00.

Melville, Fred J. All Ahout Postage Stamps. Lippincott; \$1.50. A l'enny All the Way. Mekeel-Severn-Wylie Co.; 12 ("ents.

Hoore, N. Hulson. The Old Furniture Book. F. A. Stokes Co., 1903; \$2.00. The Old ('hina Book. F. A. Stokes Co. $190 \%: \$ 200$.

Poele, 13, W. H. Beginner's I'hilately Guide. Boston, IIekeel-Severn-Wylie co.: 205 cents. 
Power, Eustace B. The General Issues of United States Stamps, etc. New York, 1909; Stanley Gibbons, Inc.

Starr, Mrs. Laura B. The Doll Book.

Whitcomb, Charlotte. Heirlooms and Antiquities (China). The House Beautiful, X, 271; October, 1901. 


\section{GARDENING.}

"When Adam delved and Eve span Which was then the gentleman."

If this old rhyme be considered an anthority, then gardening is one of the oldest of crafts. It is also one of the most delightful. Some persons lave the idea that it can only be followed out of doors during a few months of the year. But as soon as he has gotten over the Christmas holidays the true gardener is hard at work at his garden-on paper-and is laying out row: of bulbs and plants and regetables. A seed catalogme is more absorbing than a best seller, and the joy of inticipation is his to the utmost. While the patient may not be brought up to quite such heiglits as these. he may lie given a stant and the right way pointed ont to hint.

Many hospitals have a part of their whomuds set apart for patients' gardens where flower's to beantify the wards and rooms, and regetilles to add to the menu

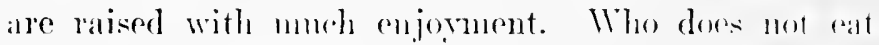
radishes fresh from the garden with a murh greater zest than those which have come from matket! There is also great pleatsure in watching plants anme from seed and srow and mature. There lecently alppeared in

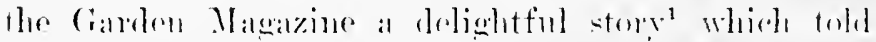

: The Garden Doctor. The Garden Magazine, XVII, I, 11; February, 1913. 
how a nervous invalid gained strength and an interest in life by means of gardening.

We may start very simply by planting a few seeds in a pot. In winter the orange and grape fruit seeds nnly be sown thickly and the rich green of the leaves makes atn attractive centre-pice. After the plants have grown to some size, the best may be selected and grown singly in pots. By this time the patient's interest will probally be aronsed and geranium or begonia cuttings may be potted. It the sime time he should be indueed to read up on the subject and plan a modest garden for the summer. If the last is impossible, the pot growing call still be continued. Much pleasure may be derived from a pot of louse iry. Making a trellis and tricining the iry over it may prove very interesting.

Should the outdoor garden be possible much pleasure may be derived from it. There are many books on the subject which may be read with profit.

Is a side issne, so to speak, to the garden work, the rose petals may be sared, after the roses have been ent and beantified the home. and utilized in a munber of lelightful wals, such als, al sweet jarr, rose syrup, randied rose petals, sandwiches, lozenges, ete.

Two writers in the Iroman's Home Companion for June, 191:j-Ifenrietta 1). Cirmel and Caroline B. King-give a mumber of recipes muder the title of How t1) ["se the June Roses, whirll are most interesting, ats a number are taken from old cook books. From this

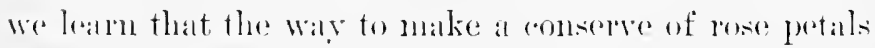
is to line "at jarr with alternate liver's of lone petals and 
sllgar until it is filled. Then it is tightly covered with heary paper and set away for three months. It the rud of that time a rich and delieate conserve has formed, which is to be served with syllabuls or whipper rream." Or "if you would have rose lozenges, boyt rour sugar to sugar again, and then put in your red roses beat to a pulp, ponr in pye plates and ent in what form you please."

\section{TO MAKE A SWEET JAR.}

Select a jar and in the bottom place a layer of cotton batting wet with a few drops of oil of berganot and tive drops of oil of rose geranium. This will cost ten rents at any drugrgist's.

Iave ready a quart of dried rose leaves; put halt uf them in the jar on top of the cotton. Mix in a few roves, a blate of marce rrmupled fine, a strip of cimma-

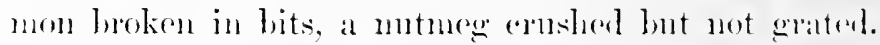
Add more of the rose leaves and on thementinkle there drols of oil of pelpermint. Tn this yon may pult a

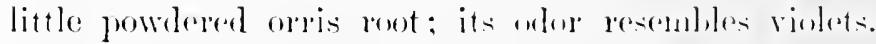

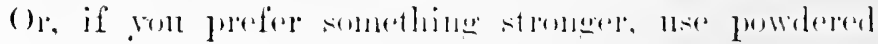
silndalweod.

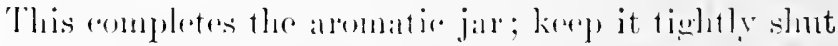
for there weelss to ripen and ambline the ofors. After this nenen the jall for a few monucuts and it will ditluse a ralle frataraluere.

Lark of spare prevents reproducing all of these in-

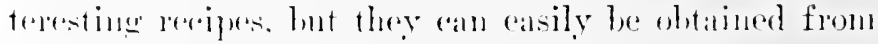
the alwse or probally from otleer hooks in the nearest 
pullic library. In another number of the Homm is Ilome Compranion, Paul P. Foster tells abont Swent Lavender and how to make sachets. Lavender grows freely in California and in some of the Sonthern States, and might be tried anywhere. I have never snceeded in growing it from seed in Maryland, but will keep on trying, which, by the way, is a good rule for gardeners to follow. It is said to grow better from cuttings than from seed.

lieferences:

Lounsbery, Alice. The Garden Book for Young People. New York, 1908, F. A. Stokes Co.; \$1.50.

barnes, larker Thayer. Suburban Garden Guide. Mar: millan, 50 cents.

Bowles, F A. My Garden in Summer. Dodge Publishing Co.

Cable, Geo. W. The Amateur Garden. Scribner's; \$1.ín.

Ely, Helena Rutherford. A Woman's Hardy Garden. Macmillan. Another Hardy Garden Book. Macmillan.

Willians. Gardens and Their Meaning.

Wright, Mabel Osgood, The Garden of a Commuter's Wife (ilossett \& l)imlal). 


\section{NATURE STUDY.}

Even if our patient does not aure for gardening, he may be induced to take an interest in nature study by the nurse pointing ont the interesting things which may be seen from a window or during a ramble. Birds. trees, wild thowers, weeds, gralsses, the soil, and the star: are all treated in popular manuals, and if the nurse knows but a little of all of these it may be enongh to "xcite the interest of her patient and stimulate a desir" for more. So many things may be observed during a walk by eyes that see. Even in city streets there arr sparrows, a few trees, and window-boxes, and prartically all cities have parks. Under such circumstances a game might be played and nurse and patient match wits to see who ean observe the greatest number of :I certain kind of olyjects.

\section{Referemers:}

Wings and Stings.

Bailey, L. H. Lessons with Plants.

Chapman. Bird Studies with a Camera.

Dana. How to know the Wild Flowers. Scribner: \$2.1w.

Going. Field, Forest and Waysite Flowers. Doubledtay, Page \& Co

Holı, Frecterick L. Nature Sumly. Scribner.

Irving. H. How to know the Trees.

Parsous. low to know the Ferns. Seribner: \$1.50.

Malton, Geo. L., M. 1). The Flower Finder. Limpineolt. 11) :34: \$2.for. A manual for the amaleur, arranged accoriing to color. Botanical terms and classification reservel chiefly for the glossary. 


\section{STENCILLING AND BLOCK PRINTING.}

\section{STENCILLING.}

Stencilling was much in rogue at one time, and. like many other occupations which have become fads. its popularity brought it into disrepute. As someone lias intly said, there is no more effective decoration when properly used, and there is no more mistaken method when erudely handled. So much work of poor design was eirculated that a prejudice was formed against it. The comparative ease with which stencilling may be done was responsible for many evidenees of bad taste. I'robably many persons have never seen a good piece of stencilling. In this work color himmony is important, probably more so than good design. On account "f the commercial exploiting of steneilling many very poor designs lave been placed on the market. and it is usially much easier, after having obtinined a good dersign, to make one's own stencil than to search for al good one at an art store. As to the origin of stencil making we know nothing. Probably all of us have reen stencils of one form or another. but for those who have not, it may he sald that "al steneil is al thin sheret "1. plate, as of patper or metal, in which al paltern is "ut through with interrupted lines or spaces or with dots, nsed by placing it on a surface and laying on a color through the open spaces. al with a hrush or 
sponge." (Standard Dietionary.) The most durable are made of very thin brass or eopper, and are nsed almost entirely to mark boxes, barrels, ete, with trademarks or lettering of some sort. Ileary paper which las been soaked with linseed oil and then dried is what is generally sold and used for the stencils which we make. The oil makes the paper tough and impervious to the color which is used. If it is not possible to obtain stencil paper we ean use any ordinary thick paper. and after we have eut our steneil, ramish or shellac it, or, which is not so good, coat it witl parrafine. Stencils must be somewlat flexible so as to conform to irregular surfaces. In making a stencil the design is drawn on paper and bands which hold the different parts together are marked. The design is then ent with a sharppointed knife, a matt knife frepnently being nsed. We are now ready to put the design on the material. Almost any smooth milterial cam be nised. To stencil "pon it, it is preferable to put a piece of hotting palper on a board. place the material on this and fasten the stencil to it with thumb tacks. Ordinaly artist is tube colors or other thick paint is used and is applied with at round, short-bristled brush which is made for the purpere. Other stiff brushes will do or loug bristle hrushes can be ent off. 'The color is rubled inte the natterial. care bejug taken not to suneatr it inte spalees where

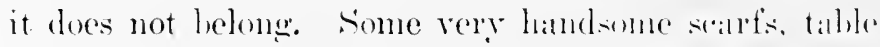

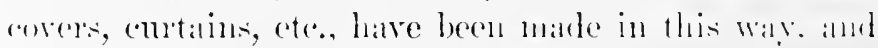

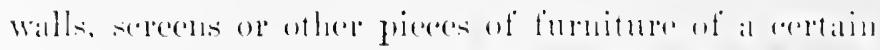
character may be beantitied be a stencilled derign. It 
is easily conceivable that a patient nuy be interested in the decoration of the walls of a room or its hangings by this means. Some very attractive dens and murseries have been made, chietly with the aid of stencils. It is an occupation which trains in color sense and design ats well as acenacy in the use of eye and hand. The slight equipment necessary and the ease with which. such can be proeured is a strong point in its firor.

\section{BLOCK PRINTING.}

This is a more difficult, lut far more fascinating craft than stencilling. It is really a craft, hence is not likely to be lightly taken up as an amusement. The patient should have some artistic ability and paticnce cnough to carry ont the somewhat tedious process required. Almost any smooth material can be used exeept rich silk and satin. The material must be more smooth than for stencilling. In choosing our design it should be remembered that we have a repeat patteru to make, or if all the material is covered. what is generally known as a diaper pattern.

Srmmetrical designs are generally chosen. Tarions kinds of wood are used. but a close-graned wood is best, such as cherry. dogwood, or boxwood. If these camnot lie secured. White pine can be used. If the latter, the side of the arain is used, if the former it is better to nse the end of the grain.

Tlle derign is drawn on or transferred to the block and outlined with a sharp knife or graver. 'The block can be made more easily and better with wood en- 
graver's tools than with any others. These ram be stcured from dealer's in printers supplies. All wool outside of the design is cut away to a suficient depth to keep it from coming in contact with the material. usually abont an eighth of an ineh, althongh it may lw. necessary to ent away nore near the edges of the blork. The material is fastened to a board over which has heen placed blotting paper by means of thumb taeks. The positions where the block is to be printed can be indieated by pins. I coating of paint is put on the block which is inverted and placed on the material. It is held firmly and struek a sharp blow with a mallet or hammer. The block is then lifted away, and if we have used a proper amount of paint there should be al clean print of it on the material. Practice only can determine the proper amomut of paint to put on the block. This can be letter donc. however. by the use of a color pad. which is made by stretehing abont a dozen pieces of checsectoth, or coalse muslin, over a block of wood larger than the printing block and sorming them by tacks aromed the edges, althomgh they may be sewn together and laid on a plate. The paint. or dre is spreald on the paud with a brush until it is saturated. Press the. wood blorek on this and wipe off the rolor. doing this several times or mutil the wood is saturated, then atain prese the wood block on the parl and it will he fomml to hase on it a thin roating of color. It is then reatr. for printing. In all cases try on a sample of the fabri, before attempting to print on the piece. In printing an thin fabries, firm, even pressure will give as satisfar- 
tory an impression as will tapping with a mallet or himmmer. The latter is necessary in printing on rougher fabrics. It is impossible to print on fabric with a pile. such as velvet. When dyes are used they should be in concentrated solution.

Some combinations of stencilling and wood block printing are very effective. One great adrantage of the latter orer the former is that the contimity of the design is not interrupted.

If it is not comvenient to procure wood engravers' tools the block may be made in other wars. The design may he sawed from thin wood with a seroll saw and the pieces ghred on a block of wood which has heen marked with the same design, so that the pieces will be placed (n) it in their proper position.

Another method which l have never seen tried. but which $\mathrm{I}$ believe ean be used, is one used by printer's in anergeneies where it is neeessary to have large type ol designs in a short time. This consists in glueing a piere of plain-faced linolemn (one which has not had paint applied to its surface) to a piece of wood. The design is drawn on this and is easily ontlined and the barekeromel cut away with a sharp knife. This is more aasily matre than a wood block, lut is probably not so diuliahle.

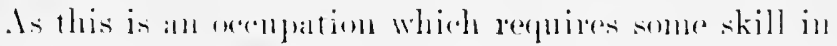
mamipulation, it shomld not he takes np until the pa-

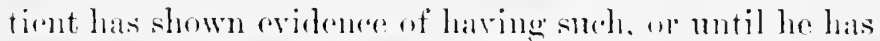

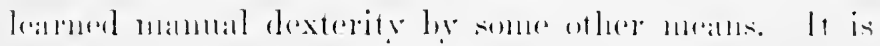

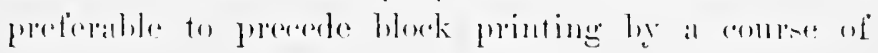


stencilling, mless the patient is already familial with the litter.

There is an excellent article on stencilliug and hlock printing in the Good Inomsokerping IIone Inandicraft Book. 


\section{PLASTIC WORK.}

The creative instinct which is in all and which in childhood canses us to make mud pies, still exists despite repression, and we would probably enjoy clay modelling as a diversion if we did not feel that other things give us and our world more pleasure. There is, lowerer, an artistic touch in many crude things, and we may be alle to derelop such in ourselves or others. ('ortainly the interest which such an art creates in stimulating us to observe form may be used to an artvantage in the mentally sick who need diversion and training. ('lay modelling is truly an art. and while onr' patient may not aceomplish anything more than diversion from muliealthy thoughts, or an interest in the study of seulpture, we should feel quite satistied with such result.

Clay modelling has one great advantage, its cheapness. The clay may be procured in several colors at art stores for about six cents a ponnd, and only requires mixing with water to be really for use. The modelling tools are of wood, are guite inexpensive, and substitutes can be whittled with a knife. The clay also can be

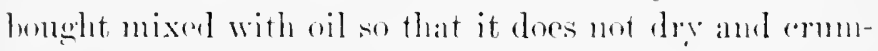
be. If the rily dongh is mixed with water it must be kept moist lye moans of wet olothes wapled about it.

As an illustration of the artistie value of erent crude thinges I might instance a Banke feapot which was bonght at the ('entemial Exhibition in 15.6. It is of 
lown earthenware with a "chimmey" in the middle: all over it are the finger marks of the potter, and the handle of the lid is a quaint little frog made from bits of clay. It is a quaint, common, little teapot with a charm of its own. due elifefly to its individuality. Iי know that other teapots made ly the same potter must show some differenoes reven thomgle slight. I number

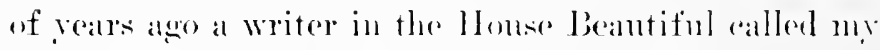
attention to this ly bewailing that this form of lianko ware is no longer made, and in its place is made a war. of rolored elays which form a design whieh goes through the wall of the vessel. This the writer dereried as boine commeredal. malchine made, etce Satmally my banku teapot had an increased value to me becanse I romld not replabe it and beeanse an anthority had rommended it. This also shows that the moge knowledge we haw of an article the more interesting will it be cres. ('ollecting.)

But to go harek to oul molst clay, there are su mally things which ean le male which may have value if well made. Vases, jars. ete. may be built up ly aojl work. the eliy be buge rolled ont in a home. narmow string-like piece, which is laid on itself to form the shape desired and then smeotherd off with the wet hand al a wet tosel. Ifor having dried thoromghly these may he tired in a

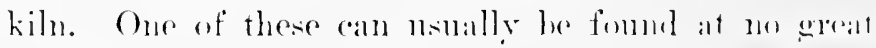
distance and the for is a small one. Clay fomml an some

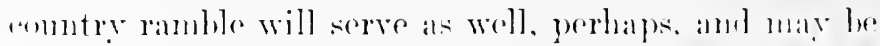
mere interesting to the pationt than that benght forem the sline 
If the patient shows sufficient ability, lessons should be taken in this fascinating art and a potter's wheel set up. It is certainly a delightful thing to see an expert potter shape a lump of elay on his wheel. and must le a delightful accomplishment.

In modelling it is well to begin by making solid oljects, the round, so-ealled, then high relief, and last, low relief. In this way a better idea of form is gained.

There is a prepared form of colored clars called Plasticine which comes in sets and is an exeellent way. of beginning clay modelling.

References:

Holland. Clay Modelling; 75 cents. The Way of the Clay; 20 cents.

Lester, Katharine. Clay Work; \$1.00. Clay Modelling in the Schoolroom: 25 cents.

Sargent. Modelling in Public Schools: tin cents. Modelling for the Standards; 60 cents.

Binns, F. The Potter's Craft; \$2.00.

White. How to Make Pottery; $\$ 1.00$.

\section{PLASTER CASTS.}

Should our patient model something that is worth keeping, but we are unable to have it fired, a plaster cast can le made. To do this a thin film of salan oil is: painted orer the olject to prevent the plaster sticking, and if the matrix, or monld, must le marle in sections on account of the form of the oljiect, a will of clay is milt along the line where the section of the matrix under construction must cleave. a retaining wall of some sort made. such as a piece of tin or wood, and the first 
section cast by pouring into the cavity made a thick cream of plaster and water. After twenty-four hours the tin, or wood, and clay are removed, the edges of the matrix are greased as well as the object and another section of the matrix is cast. Ifter twenty-four or more hours the matrix can he removed. It is well to insert pins of some sort into the rlay wall, or make depressions in the plaster of the eleavage of the matrix to form keys so that the scetions will fit well together. To make the east the seetions of the matrix are greased and then bound together. a moderately thiek eream of plaster is poured into it and the matrix turned rapidly so that the plaster is distributed about the cavity and forms a shell. Some persoms profer to make the cast solid, but it is mnecessary. Considerable time should be allowed for the cast to harden. I week is not too long. althongh the monld may be removed eanefinlly before that time olapses. A rery satisfatetory bouk on the subject is Modelling and Serolpture ly Illert Toft (Lomdon, 1!11. Serely d ('o.. Limited).

\section{STARCH BEADS.}

I rery simple form of platitic work which repuires no artistie skill is the making of stareh beals, or salt beads, as they are also called. There are a mumber of mays of making these. In one we repuire one rep of salt, a half ("up of hoilime water, and half a rup of cornstareh. Mix the eorustareh with a little water and

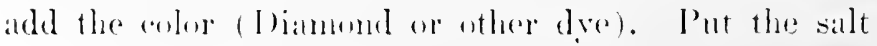


in the hot water and boil it. Add the cornstarch and mix vigorously. Oil the hands with olive oil and knead the paste while hot until it is smootl, after which the dough may be set aside and used at any time. A small piece is rolled in the hands until it is the shape desired, when it is pieroed with a hatpin and set aside to dry and harden. The beads are afterwards strung. usually as a necklace.

Another method is as follows: Take one large tablespoonful of ordinary flour, or better, cornstareh, and the same of fine table salt, mix well and sift together, add just enough eold water to make a very stiff dough, first tinting the water with any color desired. Work well until the salt is dissolved, take a very little of the dough at a time, keeping the remainder covered with a cup or bowl to prevent drying. Roll out with a rolling pin (not very thick) and cut, as are cookies, with a hand ring; then cut in two to make two beads. Roll them in the palms of the hands. which shonld be moist. String on fine broom straw and keep ont of the sum and wind to aroid eracking while drying.

These beads are usually strung alternately with glass or gilt heads, and if they have leen well colored are quite pretty.

\section{CEMENT WORK.}

('ement work has been used as an ocerupation for certain calses. and hats heen dereleped to al distinet craft lye Ih. Iferhert Ifall at his Marhlehead Simitarimu, where mily nerrous calses alre treated. It is allso ned at al number of other places. Mrexperienere with it is too 
limited to permit my expressing any deeided opinion as to its ralue. I am of the belief at present, however. that it may be of use in only a limited number of eases. Irs. Slagle believes that it is of especial ralue for senile eases, but I camnot understand how such can use this eraft except under competent direction, and then only: to a limited degree. It is a rather fascinating craft and in simpler forms is not especially diffienlt. Door porters and book rests are made, but are not very good for polished floors or tables. These are simply made. $\Lambda$ wood or metal frame of the size desired is filled witl the mixture of sand and cement. packed hard, smoother off, and a design cut in the top by the aid of a steneil or free hand. Or an ornament maly he malde in a mould and applied. After two or three hours the frame may. he removed and the cast on its boart sot aside to dry. This should not be done too puiekly or araks will show. To prevent this the east slould be sprinkled well twiee daily for at least a week.

The mixture used is the same as the finishing wat for eonerete work - that is, one part of Portland cenent to two parts of sand. A perfect sand is difticult to obtain, as that from the seashore contains salt. and that found inland usually contains aly loth of which weaken the asat by preventing a proper bonding hetween the grains of sand and the cemont. Ther sill d mily in. wathed. however. and so purified.

If a white cast is desired, a mix may be made of three parts of marlle dust to one of white cement. this being alwin thee tines more expensive than the grey. 
Moulds, the board on which the cast is made, the frume, etc., should be oiled. Dr. Hall recommends a mixture of a half pound of melted paraffin to a quart of kerosene, and cautions against its free use.

There are many little "tricks of the trade" which will he learned by experience. or can better he gotten from some book on the subject. The most difficult thing to learn is how much water to add to the mix. I would recommend, for reference, Concrete Pottery and Garden Eurniture.

1 Davison, Ralph C. Concrete Pottery and Garden Furniture; New York, 1910, Munn \& Co., Inc. 


\section{DRAWING AND PAINTING.}

While these are essentially arts and require a natural talent as well as years of training in order to achieve any success in them, if the patient shows a desire to midertake them lie should be encouraged to do so. It is, perhaps, too much to suppose that the nurse has any particular ability in either of them and so she cannot act as teacher, but she can suggest books on the subject and cam do much by encomragenent. She should bear in mind that it is better for her patient to do something badly than to do nothing at all. As a secondary oecenpation the patient may be induced to take up a study of the history of art (sce p. ti).

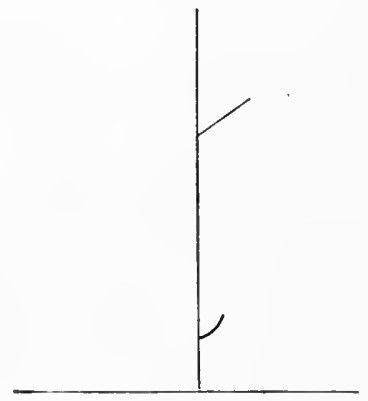

Fig. ::9.

There atresereral sinpte little dratwing tricks which the murse maly use to atrollose the interest of her patient

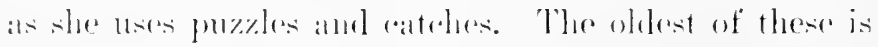
$1 ! 1: 2$ 
by IIogarth and represents a soldier and his dog going through a doorway. As is seen by the diagram, it eonsists of three straight lines and one curved one. This has been used to show the value of a line, which the following also illustrates.

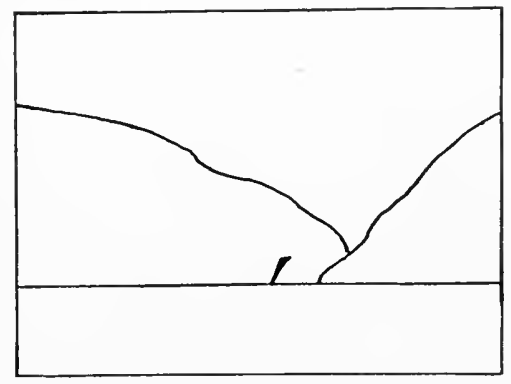

Fig. 40 .

Tere we have a view of a sailboat on the Hudson River just above West Point, although it will serve equally well for a view of Lake Como. It will be noted

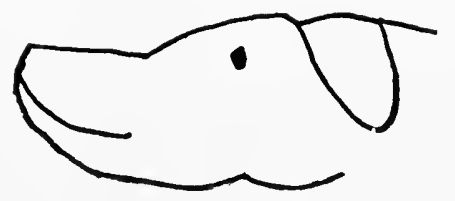

Fig. 41 .

that it has been drawn with lut four lines, not including the frame.

Another trick is to draw an outline of the thumb held sidewise and fill it in to represent a dog's head. 
Pigs drawn with one s eyes closed may be anmsing, as also the following geometrical animals.
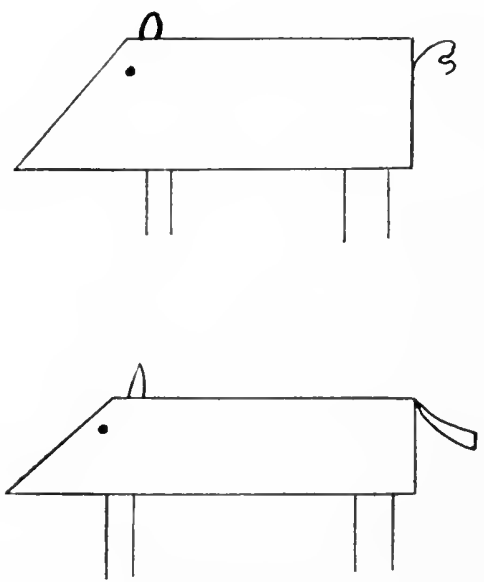

FOX

Fin. 42.

There are quite a number of these drawing trickis which the nurse may collect.

\section{ILLUMINATING.}

i brief history of the development of bookmaking has been given under bookbinding (p. 15t;). This nives Is sufficient knowledge for an understanding of the present subject, although more detail may lo easily lourned if desired. We are here interesterl in lut one

1 Encyclopedia Brittanica. Illuminated Mss, XIV, 312. Manuscript, XVII, 618. Palæography, XX, 55ti. Miniature, XVIII, 523. Typography, XXVII, 509. Printing, XXII, 350. 
phase of bookmaking, though a very delightful and interesting one. From earliest time man has ornamented his most precious possessions, and the earlier books show eridences that they were ralued by the ornamentation found in them as well as on their casings. This ornamentation usually consisted in making more or less elaborate letters, decorations, or pictures, and the process has been called illuminating. According to our oft quoted authority; the Encyclopedia Brittanica, "Illumination, in art, is a term used to signify the embellishment of written or printed text or design with colors and gold. rarely also with silver. The old form of the rerb 'to illuminate' was to 'enlumine' (O. Fr. enluminer; Latin, illuminare, 'to throw light on,' 'to brighten'), as used by Chaucer (A. B. C., 73), 'kalendres enlumined ben they', and other medieval writers." In inspection of old manuscript books shows how much they were brightened by being illuminated. Probably one of the best collections illustrating the development of books is to be found in the Library of Congress at IVashington.

In the history of illuminating there is much that is of interest. The earliest known examples are found in paprrus rolls containing the Egrptian ritual known as The Book of the Dead, and consist of scenes in colors. They date from the fifteen century B. C. Tumerous references to illuminated books are found in Latin. Aecording to Mr. Wratt:

"Martial, in lis first epistle, points nut the bookseller"s shen "lposite the Julian Formon. in which his 
works may be obtained 'smoothed with pumice-stone and decorated with purple.' Seneca mentions books ornamented 'cum imaginibus.' Varro is related by Pliny' to have illustrated his works by likenesses of more than seven hundred illustrious persons. Pliny, again, informs us that writers on medieine gave representations in their treatises of the plints which they described. Martial dwells on the editions of Virgil, with his portrait as a frontispiece. The earliest recorded instance of the richer adornments of golden lettering on purple or rose-stained vellum, is given by Julius Capitolinus in his life of the Emperor Maximinus the rounger. IIe therein mentions that the mother of the emperor presented to lim, on his return to his tutor (early in the sd century), a copy of the works of IIomer, written in gold upon purple rellum."

The character of the work in the manuseripts of the third eentury A. I). forms a comeeting link between the art of the Roman Empire and that of the Middle Ages, and may he eompared with the wall paintings of Ponpeii and of the catacombs.

There were several schools. the chief of which were known as the Bryantine, Celtic, and Carloingian or Franko-Lombardic. Of these the Celtic wals the most important, and has been deseribed as "a mechanical art brought to the highest piteh of perfection by the most skilful and patient elaloration." It is chatracterized by the nse of interlated riblons, scrolls. etc.. intemingled with rather grotesque animals, and the nee of red dots. Cold was never used. I copre of the Gos- 
pels, known as the Book of Kells, is the most famous early example and dates from the seventh ecntury. The Lindisfarne Gospels, written in honor of St. Cuthbert and completed early in the eighth century, shows the influence of the Byzantine school in the use of gold and in the treatment of some of the figures, but the greater part of the work is a perfect example of the Celtic style.

The history of illuminating cannot be further pursued except to say that with the invention of printing from movable types in the middle of the fifteenth century there came a decline in the manufacture of illuminated and written books, and few were made after the sixteenth eentury, although the names of Tan Eyck and Memline are associated with illuminating. Early in the nimeteenth century, however, there was a revival of the art, due chicfly to Dudley Costello (1803-1865) and his sister Louisa (1799-1870) who in 1835 published a book entitled Specimens of the Early Poetry of France, dedicated to Moore, which was illustrated by beautiful illuminations, and was followed by other books similarly illustrated. These stimulated an interest in the study of illuminating which still survives. While the combination of illuminating with trpe printed books has never been suceessful, addresses of a formal character, church books, mottoes, etc., are appropriate suljects.

The art is one which is not lightly to be pursued, as patience and perseverance are required to master pen and brush, but to a person of artistic tastes, it is an 
admirable outlet when the more antistic painting $01^{\circ}$ drawing is impossible. The sensory training of eye and hand makes it valuable as an occupation, especially in cases of mild depression, where concentration of attention is desired. It can easily be conceived that the number of patients who can be occupied with illuminating will be relatively small, but it is also conceivable that for certain individuals it may be of great value.

That is sometimes called illuminating. but which call hardly be dignified by the term, is the coloring or entbellishing of initial letters or ornaments in printed hooks with water color's or colored inks. 'This is a much simpler process, much less artistic, but may produce pleasing results. Totable instances of this form of work are some of the Roycroft books. Is an oceupiltion this so-called illuminating may be of value as a diversion, or as a prelininary step to engage the interest of the patient in the more ditficnlt illmminating.

The most practical work on the subject is that of Edward Johnston. ${ }^{1}$ The older work of Tymms and Wyatt ${ }^{2}$ is much more interesting from an historical standpoint, and contains a number of examples. but it (an probably only be oltained from a dealer in ald looks and many of its dirretions are out of date.

1 Johnston, Edward. Writing and Illuminating and Lettering. New York, 1906, Macmillan Co.

2 Tymms, W. R., and M. D. Wyatt. The Art of lluminating as Practiced in Europe from the Earliest Times. London (1860), Day and Son. 


\section{PRINTING.}

Is an occupation for a mentally defective patient, either congenital or acquired, printing is admirable. P'rinting' outfits may be purchased for comparatively small sums, and adequate books of instruetion aecompany them. From simple beginnings, snch as a single line on a card, the work may be developed to ornamental work in several colors or small booklets. It is a developing occupation and trains in many ways.

References:

IICClellan, George E. Practical Typography; $\$ 1.50$.

Nackellar, Thomas. The American Printer. 


\section{METAL WORK.}

Metal work may be very simple or not and in it we have a wide range in choice of occupation.

\section{PUNCHED METAL.}

l'robably the simplest form is that known as puncher hriss, which was nearly ruined by commereial expluiting. It may have considerable beanty, and is an excellent ocenpation for cases of dementia praecox or for deep depression. It consists in outlining a design. which has been drawn on No. :30 soft brass, with snall holes punched with a small awl. The backgromend is then punched with larger looles. The brass is laid on or tacked to a board while the work is being done. Very pretty boxes, teapot tiles, ete., are made from wood covered with the brass and afterwarl punched. 1 sharp nail will serve as a pmeh, and if no hrisis "an he procured, thin tin can be mate to serve.

1 moditication of the above is mate by antlining designs on hearior brass, coples or tin. 1 rhisedshaped ponnely an he filed from a wire nail and used quite efferetively for the ontlining. This work is alsu

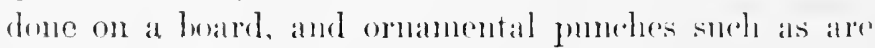
nsed in leather work am be nsed on the balckgrouml. This last wis a very pepmlar cralft thirty years ago. but has been sllperseded by the punched work noted alwere. When the omannental punches are used the metal is not perforated. 


\section{PIERCED OR SAWED METAL.}

This may be said to be the next development of metal, and as the name implies, consists in sawing from sheet metal ormaments such as escutcheons, handle plates, finger plates, etc. Practically any soft metal can be used, such as brass, copper, aluminum, or silyer.

The tools required are quite few and comparatively inexpensive, being a jewelers' saw frame with a number of blades, drills of varying sizes, files of several kinds, a hammer for straightening or bending the metal, and a small metal rise. The equipment can be extended when desired.

The design is ontlined on the metal with pencil or stylus, holes are drilled where it is necessary to take out a piece of metal such as making a key-lole, and we are ready to hegin onl sawing. 'The metal nuar be fastened in the rise, hut it is better to have a board about six inches wide fastened to the work table and projecting six or more inches from it. It is well to have this notched, like a bootjack, as it will be found that the sawing can be done more easily. 'This board is like that used for coping saw work. The saw is held rertically and it will be found that more arecurate work cam be done than if it is held horizontally, as is necessary when the work is held in a rise. Ifter onr piece is sawed ont it slould be smoothed up with fine files and emery paper.

This is an excellent ocoupation, and I have never found it to fail in helping a patient. In most anses, and especially in dementia praceox, it is well to give a 
preliminary conse in punch work in order to educate in aceurate placing of tools, or education of eye and hand. Sawed out almminmm letters riveted to a piece of copper make a very neat sign for outdoors, and the same ont a dark wood, such as wahnut or cherry, a most attractive indoor sign. The possibilities in this sawed metal work seem endless.

\section{HAMMERED METAL.}

This minally means hammered eopper, as that is soft and gives very heantiful effects, but soft brass or silver may also lie nsed. Tery beantiful bowls, dishes, and other vessels may be made as well as smaller articles. This mufortunately repuires an equipment of anvils and hammers, besides numerous other tools. Gas is necessary, or some other form of fire, to anneal the copper. Liy this we nucan softening it. Hammering ranses a rearrangement of the molecules of copper to the shape we desire. This has to be done gradually to aroid cracking, and as hammering hardens the copper. it must be lieated to a cherry red to axpand it and then suddenly aoled hy plunging it into water.

I special epuipment for this work is made up by one timn at a cost of fitty dollats.

Is it is imposible to do justion to this subject in luef sare the reader is referred to special works on the suljert. Probilbly the leset is by dugustus F. Rose.'

1 Rose, Angustus F. Copper Work. An illustrated texilook for tearhers and sturtents in the manual arts. Wor

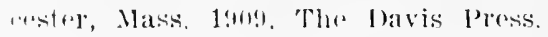

Sleffel, charles conrat. Worling in detals. boublenday, bage \& ro.. Library of llork and Play. 
If we desire a hammered effect on some of our lhat sawed work, this may be done with any dome-shaped hammer, like the ball-pein, before doing the sawing. I'ith the same sort of hanmer we may make paper knives from heavy eopper wire, or the blade of a paper knife, the handle of which has been sawed. A flatiron from which the handle has been broken makes an excellent anvil for this simple flat work.

\section{VENETIAN IRON WORK. ${ }^{1}$}

This has been a more or less popular eraft for a long time, but I camnot recommend it, as there are so many other better occupations. It consists in bending narrow strips of soft iron to form an ornamental scroll, which is adapted to many forms. These are held together with small pieces of metal ealled elasps. While some rather handsome pieces have been made, the majority of it is inartistic and fussy. It has the further disadvantage of being diffieult. All parts must be bent aeenrately or the work will not be strong, and accurate work of this sort requires eonsideralle skill. If such is to be developed it had better be for something worth while. The clasps are difficult to apply strongly. The materials are simple and the tools few: flat and round-nosed pliers. shears, hammer, small vise and anvil.

If a patient desires to do this eraft he should he given the facilities, but it shonld not be urged npon him. It

Morse, T. Vernette, Venetian Tron Work. How to Do It Series. Chicago, 1907, A. Flanagan Co. 
is apt to profuce a feeling of irritation and a sense of failure, which is very hat in any depressod case.

\section{JEWELRY.}

The making of silver jewclry is an exeellent oecupation for convalescent patients who possess a slight morhanical skill and an appreciation of beantiful things. They may become quite skilful in this delightfull craft. Instruction can usually be olstained in it at some art seliool.

\section{ETCHED METAL. ${ }^{1}$}

A very simple way of decorating metal is ly etehing with acid. After the netal hats been eleaned from grease, the design which is chosen is drawn on the motal and the background is painted orer with asphaltum paint or varnish, which may be procured at art stores. and allowed to dry. After the paint has thoromghly dried, which may require ten homrs, the metal is inmersed in a solution of one part of nitric acid to two parts of water, the acid heing adeled to the water, otherwise hurns may result from its spattering. If, after the metal has been placed in the solution, greenish fumes arise and there is active bublling. a little water shonld le atded. The time required for the etching will he from one to four homs and, metil experience has bern wained, the metal shomld be lifted from the solution

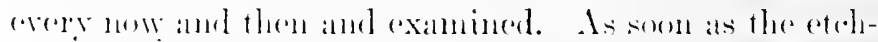

1 Adams, John D. Metal Work and Etching. Chicago. Popular Mrollanies co. 
ing is as deep as desired, the metal should be rinsed off, placed in kerosene to dissolve the asphaltum, and then wiped off with a rag, washed with soap and water and dried. The etched part may be darkened by a strong solution of butter of antimony (chlorid of antimony), the remainder polished and laequer applied to the. whole. Many very attractive things may be developed in this way. ITatpins may be made of a piece of copper about an inch square to which the shank of an ordinary hatpin is soldered after the metal has been etehed, or decorated by punches (see page 200). Book ends, paper knives, desk sets, watch fobs, and many other articles may be decorated in this way.

\section{LEATHER WORK.}

Leather work is one of the best crafts for begimners $\left(\right.$ Miekel $\left.^{1}\right)$. There are many varieties of it and persons with but little artistic ability may do good work in more than one of them. Very beautiful and useful articles can be made by those skilled in the use of the simple tools required and in the possibilities of the craft.

According to De Récy ${ }^{2}$ the methods of decoration of leather are:

Cut or engraved,

1 Mickel, Adelaide. Leather Work. Peoria, 1913, The Manual Arts Press.

2 De Récy, Georges. Translated by Maude Nathan. The Decoration of Leather. London, 1905, Archibald Constable \& Co., Limited. 
Carred,

Punched or hammered,

Modelled,

Modelled with punched background.

Leather decorated by pyrogravure and pinto grarure, Stamped.

Open-work,

Leather mosaic.

Cow and calf are the most suitable leathers for artistic work. Chamois is only suitable for stencilling or pyrography. Vellum, a very thin and stiff white skin. can be decoriated with brush or penwork. It is principally used for bookbinding.

It will be found on consulting books upon leather work that there is not an agreement as to just what each term denotes. but this is not suffieiently serions to disturb us. who must regard ourselves as tyros.

The first step, that of transferring the design to the leather, is the same in all methods of decoration. The leather must first be dampened, and here comes the first divergence. De Rícy say's to palss a soft, slightly damp sponge evenly orer the whole surfares. The leather worker who gave me the first instruction in the art. recommended that the leather be rolled in al wet towel and allowed to remain als long as neeessary. It makes little difference which method is andopted provided the leather is all dampened, for if only a part is done. it is matrked. The design should be drawn on traloing "loth if it is to be preserved and used again, but mily he on paper. It is laid on the leather in such a wa!l 
that it will not slip. The tracer, a tool with a fairly sharp point like a stylus, is then drawn over the design and will be fonnd to leare a line on the leather when the design is removed. If the leather is to be modelled these lines are again gone over with the stylus and deepened. This work should be done with the leather on a hard, smooth surface, sueh as a slab of marlyle. slate, or heary glass. Then with a modelling tool work the lackground down. This leaves the design in relief and constitutes flat modelling. If we turn the leather orer on a chamois pad, or the palm of the hand, and from the back, with the modeller foree up the design, we have what is sometimes ealled embossed leather.

If, after we have transferred our design, we incise the mark with a sharp knife to one-quarter of the thickness of the leather, we are then ready to carve or engrave it. The ineising should be done vertically; excepting where a leaf, petal or piece of detached ribbon is to be shown, when the ineising should be done slintingly under it. Incised lines should never quite intersect. If these lines be deepened and accentnated we have engraved leather.

Carred leather is more diffieult and consists in produeing lines so deep that the design stands out sutticiently from the background to allow of its heing ornamented by independent lines less deeply worked. Gravers or gouges are sometimes used for this. but require considerable skill to manipulate them. After the design has been incised, the modeller is used to press the leather away from it. and in the larger spaces a 
smooth-faced puneh is used to heat the leather down. 'This background may be then gone over with a punch which is pressed, or tapperl, with a hammer so that the backgromed is corered with the design. These punches rome in a variety of forms, and are susceptible to many "ombinations. For example. a punch consisting of two parallel lines nuy he right angled to itself and give the effect of basketry, or may simply be repeated || || || || $=\|=\|$. This is called modelled leather with pumelied harekgromud.

Hammered leather is decoratod entirely by punches. The design is usually marked with a punch making a contimuns or interrupted line, and ofluer forms are used for ormanent.

The tools need not be expensive. An orange stick may serve for a tracer, a nut pick with a broad point as a modelier, nail sets for romed punches. and other forms maly le made by entting off latere wire nalils and filing varions patterns on this tlat end.

Modelled ladture is sometimes backed with a paste of whe and whiting hefore being made mp.

Leatler maly he tinted with varions dyes or by Miggrin's waterporent inks. The rieh brown color which is sompht for is sonetines produred by suearing the leatluer with hutter and placing it ont in the sum.

Even the very ludet instruetions which have been

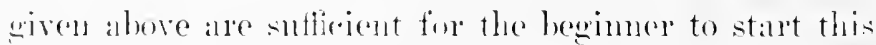
lelightful craft if he has the aldvantage of having seren pirese in the form of leather decorattion that he is alt-

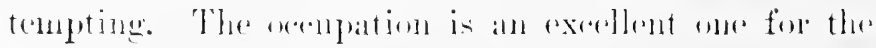


case of depression who is apt to become interested in spite of himself, and so train his voluntary attention. If he is suicidal, we must, of course, restrict him to modelled or punched leather.

A much simpler form of leather work, which camnot be dignified with the term decorated leather, consists in cutting holes in leather much after the fashion of making a stencil and lining it with chamois, silk or leather of another color.

Again, a design may be cut from leather and fastened to crash, burlap, or some other fabric by gluing, the so-called leather applique.

Leather is also burnt and painted, but these methods are much less artistic than those first given and are not such good occupations for om patients. Ooze calf, shecpskin, or chamois is generilly used in these methods.

Rieferences :

Charles. Leather Work; 35 cents.

Hasluck. Leather Work; 50 cents.

Girling, Katharine. How to Tool and Emboss Leather. Ladies' Home Journal, November, 1902. 


\section{PYROGRAPHY.}

Prrography has been mentioned as a neans of derorating leather. It is also used to decorate wood, and numy useless things liave been presented by devoten: of this craft. On aecount of the danger from tire it cannot be recommended as a craft for mental or nerrous eases. Mention is made of it here chiefly to exrhade it. It is used in some hospitals and is no doulh proper for a certain elass of conralescent or chronil. (ases. There are so many better crafts, however. that the nurse is not advised to suggest it to her patient. It is interesting to note that there is but one persin who has done noteworthy artistic work in prrography. in the last twenty years. and that is .T. Willian londick. ${ }^{1}$

1 Fosdick, J. William. The Fire Etcher and His Art. ladies' Home Journal, September. 1896.

Rainey, Ala. The Decorations of a cothic Studio. The New York Home of J. William Fosdiek. Arts and Decoration, IV, 341: July, 1914. 


\section{NEEDLEWORK.}

Lest some unkind critic insinuate that a mere man cammot know mueh of this subjeet, let me explain that throngh a book anction (see p. 171). I aequired The Inluminated Book of Seedlework ${ }^{1}$ and therefore my knowledge is extensive.

This volume elaims that needlework belongs to woman, that man has nothing to do with it, yet gives as the first needlework the fact that "They sewed themselves fig-leaves together. and made themselves aprons." which to any muliased person would prove that Adam was quite as much of a needleworker ats Eve, but woman-like the author ehanges the subject and talks at some length about "Banian trees." I wish that it were possible to quote freely from this delightful book. as it is so full of historieal reference. to Hannah, Doreas, the building of the Talbernacle. to the needlework of the Egyptians, Greeks and Romans, "Sheeschools" (eonvents), that of Mary Queen of Seots, the Bayenx tapestry, of the times of romance and chivalry, and mueh more, but it is quite impossible and only hrief references can he made. A Wiss Lin-

1 Owen, Mrs. Henry, and the Countess of Wilton (Editor). The Illuminated Book of Needlework; comprising knitting. netting, crochet and embroidery. Preceded by a History of Needlework, including an account of the ancient historical tapestries. London, 1847. Henry G. Bohn, York Street, Corent Garden. 
wood is spoken of as achieving: "the triumph of morlern art in needlework," by her copies in worsted of paintings, such as Carlo lolei's "Salvator Mundi" for which she refused three thousand guincas. Nearly one hundred pieces of varions sizes were made by Miss Linwood. who had made two or thee before her twentieth year and whose last piece. The Judgment of Cain. was finished in her seventr-fifth year after ten years work on it. Iler work was evidently a form of tapestry.

The following quotation is of interest: "The style of modern embroidery, now so fashiomable from the Berlin patterns, dates from the commencenent of the present century. Mlont the year $180 t-5$, a printseller in Berlin, named Philipson, pullished the first coloured design, on rhecked paper, for needlework. In 1s 10, Madanne Wittidh. who, being a very acoonplished embroideress. pereoped the great extension of which this branch of trade was anpahle, indueed her husband, a book and print-seller of berlin, to engage in it with spirit. Fem that perind the trade has gone on rapidly inereasing. thongh within the last six yousts the prengesion las been intinitely more rapid than it had previonsly heon, owing to the mumber of new publishers who have engaged in tlos trade." ('hapters alle wiven over to tapestry, stitchery, embroidery, and nedlework on looks. This first part rums to wore ton

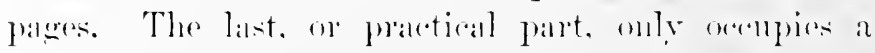
little over 100. The word illmunated is uned in the 
title because most of the dialgrams used to illustrate this part are handcolored.

We learn that "embroidery, or as it is more often called, Berlin Wool Work, has been brought to such a high state of perfection * * * * that we do not hope here to be able to throw much new light on the subject." Evidently Mrs. Owen did not have a prophetie eye; but who could be expected nearly seventy year:; ago to have forescen the great development which has taken place in embroidery! Probably all are soncewhat familiar with the term Berlin Wool Work from the older English novels of such writers as 1)irkens, and it seems proper to speak of that period as dating from albout $18: 30$ to 1870 .

It the Centemial Exhibition in Philadelphia in 1Sit; there was an exlibit by the Needlework School of the South Kensington Museum in London. This gave a great stimulus to needlework in this comutry. and during the few rears following many "Schools of Art Needlework" or "Societies of Decorative Art" were formed. These, with mumerous periodicals, have done much to encourage the art.

Infortmately the art of plain sewing was neglected. and it is only in recent years that efforts lave been made to teach children how to make or mend things in a way that does not advertise flanntingly that they are patched or darned. In the sampler period, patching and darning was an art. Sclinol children now have classes in plain sewing and various sewing cards are published as guides for this work. These may be very 
useful to a nurse who is in charge of a demented or feeble-minded patient who has never been taught to sew. Dressing dolls for a fair or other purpose makes a good object for such work.

Besides doll or adult elothing there are a liost of things which can be made. and suggestions for which are constantly appearing in periodieals.

\section{CROSS STITCH WORK.}

The simplieity of this work and the quaintness of the designs have made it popular reeently. By it most attractive motifs may be given to dresses or their accessories. It may be used solid or merely to outline a design. It is usually done on a coarsely woven fabric, which gives opportmity for easily plasing the stitehes. or when done with worsted, upon canvas, so called. a stiffened openwork fabric with double threads, every fifth space transversely being marked with a dark thread. Onr mothers used this to make elaborately designed roverings for furniture, some of which were very horrible. Nowadays it is used more for golf rests, or old-fashioned pin-cushions.

Tu the previonsly mentioned book on needlework. thirty-two of these "enbroidery" stitehes are given. They ramuot all technically be ealled ross stitches be(‘nuse some do not eross others, but all are to be used on cauras or coarsely woren fabric. Some of these make such effective work that they are given here. I tapestry needle is used. 
1. Tent Stitch. This is done by passing the thread over the crossings in the canvas and makes a solid, plain background.

2. Cross Stitch. The thread is brought over the

Tent Stitch.

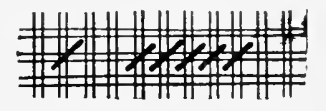

Cross Stitch.

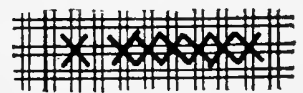

Feather Stitch.
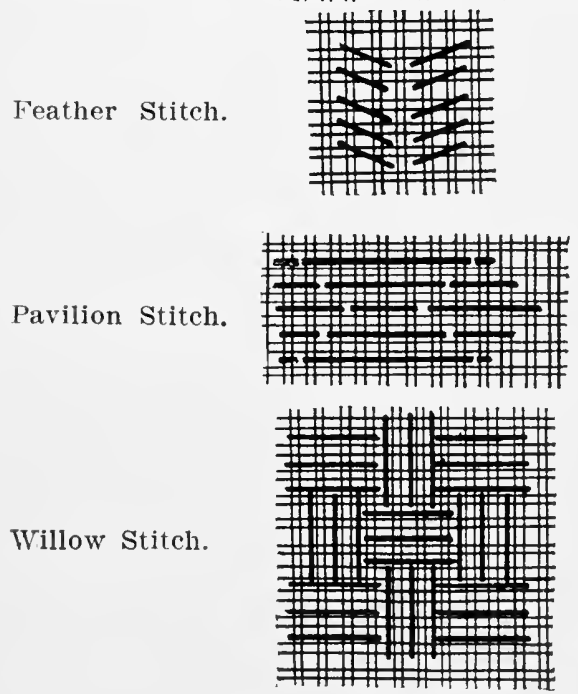

Fig. 43.

(rossing like the tent stitch, and then bronght up through the next hole so as to cross the stitch just made at right angles. It is this stitch which his heen 
so popular reently to ormament towels (guest towels), bags, ete.

3. Feather Stitch. This is quite different from what is known as feather stitching and consists of long diagonal stitehes lying parallel, rows of which alternate with similar stitches lying at an alteruate angle. The effeet of these two rows is that of the harbs of a feather. This is sometimes inereased hy a single row of eross stitches between these row. which represent the shaft of the feather. The yarn is misully put over one double thread of camvas rertirally and two horizontally.

4. The parilion stitch is very pretty and eonsists of stitehes on a common axis covering 1 , :3, 5. :3. 1 rows of the double threads of the canvas, and repeat. Below a row of these there are placed stitches covering $7,5,3,5,7$ donble threads of the eamras. These rows altermate.

5. What is called a willow basket stitel is marle ly a row of 3 stitches end to end, each going over $t$ double threads of eanras, with the next row lring at right angles to the first jow. giving the effect of a woren willow basket.

Many other eombinations cam be made which produce good effects.

In doing eross stitcll work it is well to have the pattient work ont original designs with colored crayons: on cross ruled papere as this nakes a diversion, pert is relsely anneded with the work. In the beginning it is well to get a fow of the published designs in order to 
learn the principle. The patient should be taught to work them in rows, counting and using but one color at a time, beginning with that color which is chiefly used. There is more pleasure in this and it is much better for the patient than to work on material which has already been stamped.

\section{EMBROIDERY.}

A great many other varieties of stitches are used in embroidery, and these can be learned from books on the subject or the advertising of makers of embroidery materials. Most supply stores give lessons as a preminm for so much material bought. The subject is too large and has too many branches to be discussed here. The Encyclopxedia Brittanica contains a very interesting article on the subject.

\section{APPLIQUE WORK.}

Applique work consists in sewing on one fabric a design cut from another fabric, or of another color. Some old patchwork is really applique. By it effects may be gained much more quickly than by embroidery and some very beautiful pieces may result from a combination of the two. The art is a very old one.

The applierl piees are fastened to the fabric by a variety of stitches, the most common, perhaps. being the buttonhole stitch. If a cord is nised to show a line or vine, it is couched down. The best effects are produced hy simple conventional designs, and the re- 
strained use of color. A ehild's nursery blanket of red or blue flannel figures on white or buff, illustrating some nursery rhyme, would appear better than if an attempt is made to have the applied pices in their natural colors. It can readily be seen how such a work as this can be made a developing oceupation. the rhrme being selected, the crude design made and claborated, the patterns eut from paper, then from the fabrie, then baisted in place, and finally finished with some more elaborate stitch. An excellent article on this work appeared in Good Honsekeeping. ${ }^{1}$

\section{PATCH WORK.}

Patch-work is but little used in these days when machine wearing has made fabrics so much cheaper than formerly, and when there is less necessity for saring material. and time has a higler value. 1 humdred years ago it was necessary to save seraps and piece them together to make bed-quilts. The housewife exereised her fincy, or good taste, and did her piecing in regular patterns. over two hundred of these heing known. It was left to a more degenerate age to originate the irregular pieeing to which the name crazy has been given. A number of these designs are formed by applique work. they numally heing called sewed-on quilts. The applied pieces are sewed on with the whip stitch. The scraps having been collecterd the pieces ane wht to the forms desiresl. often

1 Wilson, Alire. Applique Work. Goml Houselieeping. 
being baisted to a piece of paper while being joined together, in order to preserve the form. The piecing is done with a plain stitch in pieces about a foot square which are called blocks. A number of these are joined together to form a quilt. This is made with a lining of plain fabric, between which is placed cotton which is held in position by quilting-that is, the whole quilt is stitched through in lines which form designs which may add much to the beauty of the quilt. Much romance clusters around quilting and many writers have used it as a theme. To the one piecing patch-work the various seraps of material used may bring up pleasant memories.

\section{BEAD WORK.}

As an oeeupation requiring patience and perseverance bead work has few rivals. On this account it is especially valuable for cases of dementia, or of restless depression, though the nurse should be careful that it does not become too much of a task, and must give frequent encouragement, as the progress of the work is necessarily slow.

There are many rarieties of this work. The first is stringing beads of rarious kinds to form watch chains, neck chains, fan chains, etc. Usually this is done on one string, but when two string's are used smaller beads may be utilized to give some umusual effects, as when both strings are passed through one bead, then each through a bead, repeating until the length desired is attained. 
Belts may be woren on a special head loom (Apache loom) which may be bonght at most fancy work stores. Or may be made on two strings, each of which passes through the same set of heads from opposite ends, and run transversely to and fro the length of the belt. Or the beads may be sewn singly, or in short strings, or in long strings which are conched down, to belts, bags, purses, slippers, ete., to form an isolated ormament or to appear as solid.

Most of the Indian work is done in short strings. The single sewing of beads on canvas or linen probably emes from the Tetherlands and Germany and is silid hy one writer" to date from the "Berlin Wool "Work" period, which, as we already know; wats about $18: 30-70$. "In some of its productions it is very bad, while in others it is antistic and beantiful."

Most of the solid bead work is crocheted with silk, and in recent years there has been a revival of the old-fashioned lead purse with its gay roses, or more solver formal patterns. The last are less ditilenlt to do. als loarl work is mide in straight lines at right angles, and a sinple repeaterl figme (am be expresised moner ralsily than an rhaborate one which rerpuires rulverd lines. When but ane lind of heasl is to be

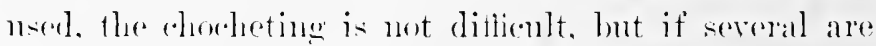

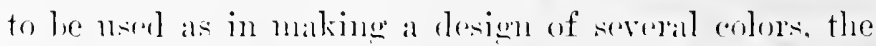
dexign must be andefully studied and the beats stmen in the proper order. ('ross stitch designing may be

1 Wilson, Mrs. Bead Work for Bags and Trimmings. Ladirs Home Journal, January, 1947. 
a great help in this, but the worker must know beforehand exactly where each bead or stitch is to be placed. On this account it is better for our patient not to attempt this form of bead work until she has had practice in sewing on single beads and crocheting designs of a simple kind.

The Professor of Ceramics of Newcomb College, Louisiana, from which so much good work has emanated, has told ${ }^{1}$ how to make beaded lamp shades which must be very beautiful. A brass frame covered with wire gauze is used as a foundation, on which the. beads are embroidered elosely together with fine wire. This is said to be more tedious than that of weaving with rertical and horizontal wires, as belts are woven on the Apache loom. Two wires go through each bead so that the work will be strong, but it would seem that as the work is done on a frame this is unnecessary. It would be an interesting problem for nurse and patient to work ont. Cross stitch designs would naturally lend themselves to this form of bead work.

Bead work is not especially cheap, hut may be very durable and beantiful. Linen thread should always le used for stringing.

1 Sheerer, Mary G. Beaded Lamp Shades. The Circle, Nay, 1907 ; p. 329. 


\section{PHOTOGRAPHY.}

Photography is made so simple for us nowadays by "you push the button and we do the rest." that some persons have the idea that it is too meehanical to be interesting; but even though the patient does not do his own dereloping and printing, there is much in choosing artistic subjects, seeing that they are properly lighted, and a number of other details.

Several years ago there was published in the Strand Magazine an article entitled "The Pageant of the Months," which was illustrated by twelve views of the same scene photographed during the different months of the year. This would seem to be an excellent idea and a favorite view taken at different seasons or at different times of the day would be an interesting study, and a series of such pictures would form an attractive sonvenir. Especially if these riews were taken by colored photography wonk they be beartiful. What homelover but would be pleased to receive on Christmas morning four views of his. home taken at the different seasons of the year.

Still life of various sorts, or posed pictures illustrating some story or poem might have a eommercial ralue, lesides being interesting to the person taking them.

Instructions for taking photographs are to be found in the pamphlets published ly cameria makers or may. 
he found in more pretentious books. Experience and practice are necessary to acquire and are perhaps the hest teachers.

\section{TINTING PHOTOGRAPHS.}

Tinted photographs may be very beantiful, as, for example, those done by the Japanese. It is not especially difficult and a small outfit for the purnose may be purchased at art stores.

\section{BLUE PRINTS.}

If the patient does not care to take photographs, and if on account of the expense, or for some other reason it seems inadvisable as an occupation, a much simpler one, which is a step in making photographs, is to make blue prints. The printing frame is not expensive and the paper can be bought already prepared or ean be made very cheaply, as follows: For white on blue ground use the following: Dissolve $1 \frac{7}{8}$ ounces of eitrate of iron and ammonia in eight ounees of water, and mark $A$. And in another bottle dissolve $1 \frac{1}{4}$ ounces of ferricyanide of potassium in eight ounces of water, and mark $B$. Mix equal parts of $A$ and $\mathrm{B}$, and apply with brush or by floating the paper in a bath of the mixture for three minutes; then hang the sheets to dry in a darkened room.

For black lines upon a white ground use the following: Water, 9 ounces; gelatine, 3 drams; perchloride of iron solution, U. S. P., 6 drams; tartaric acid. :) drams; ferric acid, 3 drams. 
Filter off any precipitate that mily be found, and roat any good, stout white palper with the full-strength solution. Expose in smlight till details of lines are visible, and develop with gallie aleid. 6 drams; alcohol. 6.1 ounces; water. ::2 omuere. Wash well in several rhanges of water.

Brown ferreprissiate prints mily be made on blue print paper which is treated in the nsual way. It is then washed in one part of ammonial to nine of water mutil nearly white, when it is rinsed and placed in a toning bath of one part tamnic aceid to fifty of water nutil it is a decp sepia color, a process which may take sereral hours. After this the print is washed and driod hetween hotting paper.

Varrous flat oljeets can be printed in silhonette, and this method is need to impress the various slanpes of leares upon children engaged in nature study. Leaves. ferns, grasses, and other objects cam also be used. One writer hats recorded how freizes of leaves and forms were mate, or note decorative palnels. or I luteh tiles from negattives of hoats. windmills. ate.

1 Ayers, B. A. In Blue and White. Some luses of hlue prints. Latlies' Home Journal, September, 1897. 


\section{MUSIC.}

Music should be made a part of the patient's daily program for many reasons. It is best, as a rule, if the patient sings, or plays some instrument, but it is not necessary. If it is impossible to attend eoneerts, these should be brought to the patient by means of one of the many meehanical devices. A player piano gives greater opportmity for expression than do the disk playing machines, but is more expensive. Any family can afford one of the latter, and will make sacrifices to secure one if they are made to realize that its use will be of value to the patient. 


\section{CONCLUSION.}

In the foregoing pages an attempt has been made to express certain general principles of ocenpation therapy, to give a number of special directions which, it is hoped. will be of value in certain cases, and to tell brietly how these things shonld be done.

IIow successful has this attempt been? That is a question which time alone can answer.

Criticism may be made of certain light or jesting remarks which appear here and there. They are present with the hope that the work will be pleasanter reading and, on account of the association, that certain farcts will be more apt to be fixed in memory. Precedent for such a proceeding is not lacking.

Much more might have been written of waly to do things. but it is felt that snch would merely be a repetition of what hals already appeared in other places. That so much has been given is hecante it wats thonght that the nurse slond have the gromd work for varions occupations in a convenient form. and only by giving them could comment properly be made upon these or"upations. The main olject has been to point out the lenedite to be sained by ocenpation. and to indiante low eretain ones might he applied ats a therapentie

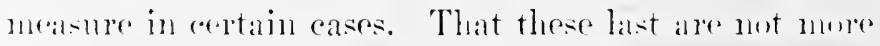

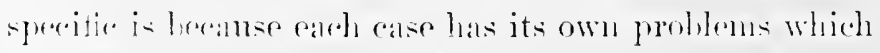


cannot be solved until they are met with, and it is wiser to give only general rules.

There is a strong temptation to reiterate mueh that has been said in order to emphasize it, but perhaps it is well only to again urge the nurse to perfect herself in one craft in order that it may serve as her hobby and safety valve, and to repeat these cardinal rules in applying oceupation therapy:

1. The oceupation should be new-that is, something to which the patient is not acenstoned, in order to arrest and hold his attention.

2. One oceupation should not be followed to the point of fatigue. A change of ocenpation may be the best form of rest, as throwing a ball or bean bag after sitting over leather punching, or taking a walk after being at work at a loom.

3. The work should be useful and the patient should he shown what this use is. Aroid aimless work.

t. It should preferably lead to an enlargenent of the patients mental horizon, and a study and interest in associated things. It is for the reason that the nurse may appreciate the greater interest in an occupation if such are known that the historical and other farcts have been introduced in this book.

5 . The nurse should participate in the occupation and show an interest in it.

6. The patient should be encouraged by praise, and criticism should be given sugar coated.

7 . It is better that the patient do bad rork than none at ail. 
If the murse masters the above she will undoubtedly be suceessful in applying ocrupation as a therapeautic measure and it is hoped that this little book will help in their mastery. 


\section{BIBLIOGRAPHY OF OCCUPATION THERAPY.}

The following bibliography on occupation theraly is the most complete known. As will be noted, the additions in recent years have been more numerous, indicating a greater interest in the subject.

Allinson, H. E. The moral and industrial management of the insane. Alienist and Neurologist, vii, 286-297, 1886. Anderson, Paul V. The value of employment in cases of dementia praecox. Charlotte Medical Journal, lx, 19, 1909. Antonoff, E. Y. Physical labor as a means of treating mental diseases. St. Petersburg, 1889, 80

Barton, George Edward. A view of invalis occupation. Trained Nurse and Hospital Review, lii, 327, June, 1914. Barton, George Edward. Occupational therapy. Trained Nurse and Hospital Review, liv, March, 1915.

Barton, "George Edward. Occupational nursing. Trained Nurse and Hospital Review, liv, 335, June, 1915.

Bltimer, G. Alder. The medical and material aspects of industrial employment of the insane. Proceedings of the American Medico-Psychological Association, iw, 230. 1897. Booth, Carolyn. Entertainment for convalescents and invalids. Chicago Medical Recorder, June 15, 1911.

Bower, D. Employment in the treatment of mental disease in the upper classes. Journal of Mlental Science, xriii. 182. Bower, D. Treatment by occupation in an English private asylum. Transactions of Ninth International Medical Congress, Washington, 1857, y, 2.79-281.

Bratten, F. D. Some problems involved in providing for the personal welfare of insane women. IIimnesota Quarterly, ix, 48. November, 1909.

Browne, W. A. F. The moral treatment of the insane. Journal of Mental Science. $\mathrm{x}, 1864$.

Browne, W. A. F. On rewarling and employing patients. Journal of Mental Science, xxix, 1883. 
Iiurnct, Anne. Re-edueation of the insane. Bulletin of Iowa State Institutions, xi, 45-49, 1909.

Cameron, Reba G. Industries and Amusemenis. The Traincd

Nurse and Hospital Review, August, 1914.

Carlisle, Chester L. A graded and systematized plan of o::tdoor exercise for the demented insane. American Journal of Insanity, lix, 637 .

Carroll, Robert $S$. The therapy of work. Joirnal of the American Medical Association, liv, 2082, June 13, 1910.

Cohn, Eugen. The systematic occupation and entertainment of the insane in public institutions. Journal of the American Medical Association, 1, 1249, April 18, 1908.

Cohoon, E. H. The therapentics of industrial occupation in the treatment of the insane. Report of the Superintendent of State IIospitals for the Insane to the Boand of State Charities and Corrections of Rhole Islan!l for 1911, 1). 29 .

Crumbacher, W. P. Diversional occupation for the insan:. Bulletin of Iowa State Institutions, July, 1913.

Jumion, W. R., Jr. A nurses' ocrupation course. Procedings of the American Medico-Psychological Assoration, xix, 269,1912 .

lunton, W. R., Jr. Oceupation as a therapeutic mrasure. Medical Rocord, lxxxili, 38s, 1918.

Dunton, W. R., Jl., Chatiman. Report of the committec on diversional oecmpation. Procerdings of the American Ntdi.o-Psychological Association, xxi, 1:S, 1:14. Also in American Journal of fnsanity, lxxi. 211, July, 1911.

Editorial. The moral tratmont of insanity. Amerioan .Ion:nal of Insanity, is, $1,1847$.

Eelitorial. Occupational treatment of insanity. Tedical Record, lixx, l:3, 1911.

Elitoral. Oconpation for convalescents. Medical Recori, l:xxiii, 7(:), 1913.

Everett, Elwarl A. The treatment of nevous and merntal discases by oecupaional mothods. The llamenannian Monthly, Angust, Is12.

Firlus, cisace L. The effort of oceupation mon the iustividual. Amerion Jomrnal of Insanty, lxviii, 10:3, 1911. 
Francis, L. Outdoor work as a remedial agent in insanity. Journal of Mental Science, xxxiii, 364-372, 1887-8.

Geissler, G. Bedeutung und wert der Arbeitshandlung Nervenkranken. Muenchener Medizinische Wochenschrift, liii. Abstracted in Journal of the American Medical Association, xlv, 431, August 5, 1905.

Goss, Arthur V. Occupation as a remedial agent in the treatment of mental diseases. American Journal of Insanity, Ixx, 477, 1913.

Gross, Ellen Kate. Occupation and recreation classes for the insane. Maryland Psychiatric Quarterly, 1, 72, January, 1912.

Hall, Herbert J. Work-cure. A* report of five years' experience at an institution devoted to the therapeutic application of manual work. Journal of the American Medical Association, liv, 12, January 1, 1910.

Hall, Herbert J. Manual work in the treatment of functional nervous diseases. Journal of the American Medical Association, 1v, 295, July 23, 1910.

Hail, Herbert J. Hospital and Asylum workshops: Some possibilities of handicapped labor. Journal of the American Mellical Association, lxi, 1976-1977, November 29, 1913.

Hamlin, F. M. Schools for the issane. American Journal of Insanity, lviii, 141-150, 1901.

Haviland, C. Floyd. Discussion on occupations for the insane and their therapeutic value; What is now done and what if anything further should be done. New York State Hospitals Bulletin, Nay, 1912.

Haviland, C. Floyd. Occupation for the insane. Proceedings of the American Merlico-Psychological Assoriation, xix, 249, 1912. Also American Journal of Insanity, lxix, 4.).

Ferring, Arthur P. Dirersional occupation of the insane. Proceedings of the American Medico-Psychological Association, xix, 245-249, 1912.

Herring, Arthur P., Clatiman. Report of the committee on the diversional occupation of the insane. Proceedings of 
the American Medico-Psychological Association, $\mathrm{xx}, 40$, 1913. Also in American Journal of insanity, 1xx, 246, July, 1913.

Husted, Mary Irving. Industrial work and the value of reeducation. Clifton Medical Bulletin, i, 63, July, 1913.

Hutchings, R. H. Demonstration of work done by patients in kindergarten. New York State Hospitals Bulletin, May, 1912.

Jacoby, G. W. A colony sanitarium for the nerrous and neurasthenic. A much needed philanthropy. New York Medical Journal, lxxxvii, 719, April 18, 1908.

Jarvis, Edward. Employments for mechanical and other patients in the British Innatic asylums. American Journal of Insanity, xix, 129, 1862 .

Jones, Edith Kathleen. State control of hospital libraries. American Journal of Insanity, lxviii, 709, 1912.

Jones, Edith Kathleen. Library work among the insane. Bulletin of the American Library Association. vi.

Jones, Edith Katlleen. The value of the lilirary in the losspital for mental disease. Maryland Psychiatrie Quarterly, iv, $8.13,1914$.

Jones, Fuith Kath!een. "Culture courses" in training schools for nurses. The Modern Hospital, iii. 1914.

Layoure. Charles T. The value of systemic teaching in cases of dementia praecox. Alienist and Nenrologist, xxxi, 1!11".

LaMonre, Charles T. The reeducation of the insane. Maryland Psychiatric Quarterly, i, 37. Octoleer. 1911.

Lalioure, Charles T. Reeducation of dementia praerox cases and industrial training of the chronic cases. Procesdings of the American Merlico-Psychological Association, $\mathrm{xix}, 26: 8,1912$.

LaNonre, Charles T. Toy making as an orculation for the insane. Naryland Psychiatric Quarterly, iii, 16. 191:?.

Lindsay, W. Iauder. Reprint from the renort of James Murray's Royal Asylum, Perth, Scotland, for 1stit-f,1. Maryland Psychiatric Quarterly, iii, 10, 191:.

Marie, Inr. Work in the treatment of the insane. Rerue fo Psychiatrie of de Psychologie Experimentale, $x, 1$, $19+1 \%$. 
Moher, Thomas J. Occupation in the treatment of the insane. Journal of the American Medical Association, xlviii, 1664, 1907. Abstract in American Journal of Insanity, lxiv, 212. Neff, Mary Lawson. Occupation as a therapeutic agent in insanity. Nedical Record, lxxviii, , December 3, 1910.

Neff, Mary Lawson. The use of waste materials. Maryland Psychiatric Quarterly, iii, 9-14, 1913.

Neff, Mary Lawson. The minimizing of insanity. Journal of the American Medical Association, 1xi, 559, August 23, 1913.

Neff, Mary Lawson. Hilda's pillow: Healing the insane through work. The Craftsman, xxvii, 99, September, 1914. Neff, Mary Lawson. A model program for a ward in a state hospital. Bulletin of Iowa State Institutions, July, 1914.

Nickerson, Mary A. A plan for the re-education of dement:a praecox cases. Maryland Psychiatric Quarterly, iii, 7, 1913.

Paidoleau, A. De la medicine morale dans le traitement des maladies nerveuses. Paris, 1864.

Parigot, A. General mental therapeutics. American Journal of Insanity, $\mathrm{xx}, 300,1863$.

Purdum, H. D. Report of the re-educational work at Bay View Asylum. Maryland Psychiatric Quarterly, 1, 68, January, 1912.

Purdum, H. D. The psychotherapeutic value of occupation. Maryland Psychiatric Quarterly, i, 35, 1911.

Ray, Isaac. Labor in principal hospitals for insane in Great Britain, France and Germany. American Journal of Insanity, ii, 359, 1846.

Ray, Isaac. The labor question and hospitals for incurables. Reprinted from Report to Corporation of Butler Hospital for 1865. American Journal of Insanity, xxii, 439, 18, 1866.

Ricksher, Charles. Occupation in treatment of insane. Illinois Medical Journal, April, 1913.

Sanborn, Bigelow T. Employment of the insane. Transactions of Mraine Medical Association for 1887, 211-220.

Schwab, Sidney I. Therapeutic value of work in hysteria and neurasthenia. Interstate Medical Journal, ix, May, 1902 .

Slagle, Eleanor Clark. History of the development of occupa- 
tion for the insane. Maryland Psychiatric Quarterly, iv, 14, July, 1914.

Smith, S. Compensation of insane labor, suggestions in regard to the better organization of a system of labor for the chronic insane. Proceedings of Conference of Charities of $1884,222-228$.

Stelman, Henry R. The art of companionship in mental nursing. Boston Nedical and Surgical Journal, 1914.

Thayer, Addison S. Work cure. Journal of the American Merlical Assoeiation, 1i, 148.-148T, October 31, 1909.

Tomlinson. H. A. The infuence of occupation in the prevention of mental reduction. IIinnesota Quarterly, November 1907,39 .

Tracy, Susan E. Stulies in invalid occupation. Boston, 191?. Whitcomb and Barrows.

Van Nuys, J. D. The value of oceupation in the treatment of the insane. Sixth Semi-annual Buletin of Kansas State Charitalle Institutions, February, 1911.

Veraguth. Otto. Ueber Arbeitstherapie. Therapie der gegn wart (Berlin), xlvi, 190.). Abstracterl in Journal of the American lledical Association, xly, 662, 1905.

Wade, J. Percy. Remarks on oneupation of the insane. Maryland Hospital News, November, 1908 .

Wale, J. Percy. Ocenpation of the insane. Maryland Psychiatric Quartelly, i, 11". 1911.

Wardner, H. Ocmuation in treatment of insanity. Transactions of Ninth Intemational Medical Conuress at Washington, 1857, v, 273-27s. Also in Alienist ant Nello'ogist, ix. $227-2966,1888$.

Winterode, Rohert P. Romedial, esonomis, ansl othical value of employment of patients as utilized in siate hospitals. Xlaryland Medical Jounal, liii, 2.:11, Octoher, 1911.

Viest. Anna. Beschaftigungshuch fuer Kranlse mn Reknnvalescenten.

Zeller. George A. Nole work and recreation for the whronic insane. Kansas ('ity Medical Index-Lan*et, October, 1!10. 


\section{REFERENCE IS ALSO MADE TO THE SUBJECT IN THE FOLLOWING BOOKS:}

Barrus, Clara. Nursing the Insane. New York, 1908, Nacmillan Co. Chaptel on Amusements and Occupations.

Baker, Ray S. New ideals in Healing. New York, 1909, F. A. Stolies Co.

Cannon, Ida M. Social Work in Hospitals. New York, 1913. Servey Associates. Chapter on Medical Social Problems. Deers, Clifford W. The Mind that found Itself. New York, 1908, Longmans, Green \& Co.

Cabot, Richard C. What Men Live By. Work, Play, Love, Worship. Boston, 1914, Houghton, Mifflin Co.

Gulick, Luther MI. Mind and Work. Chapters on Handicaps, and The Spirit of the Game.

Partridge, C. E. The Nervous Life. Chapters on Recreation, Work, The Individual.

Nusgrove, C. D. Nervous Breakdowns and How to avoid Them. New York, 1914, Funk \& Wagnalls Co. Chapter on Holbies, etc.

Witmer, Lightmer. The Special Class for Backward C'ildren. Chapters $\mathrm{V}$ and VI. 



\section{INDEX}

A.menicax literature, 46,48 Applique work, 217

Arrow, 142

Art, 46,47

Asylum, Friends', 14

Attention, 24, 120, 153, 198, 209

BAg, Macramé, 97 raffia, 97

Bars, 94

Bases, basketry, 128

Basket, Japanese flower, 148 Madeira fruit, 148

Baslietry, 131 bases, 138 borders, 143 handles, 146 stitches, 151 weaves, 141

Beadwork, 219

Beads, starch, 188

Bed table, 121

Bibliography, 229

Bight, 82

Binding, pampllet, 159 stabbed, 160

Black line paper, 223

Blankets, Indian, 105

Block printing. 184

Blue prints, 22:3

Bookbinding, 156

Book collecting, 170 scrap, $16 ; 0$

Borders, basketry, 148

Braiding, 87

C.xixg chairs, 154

Cap, taloggan, 102

('arrl games, 5:5

trick, 56
Casts, plaster, 187

Catches, 38

Cat's cradle, 62

Cement work, 189

Chair caning, 154

Chicago School of Civics and Philanthropy, 15

Christian Science, 46

Cleveland, Grover, 22

Clothes, doll, 214

Clove hitch, 84

Coil work, 150

Collecting, 166

books, 170

stamps, 167

College, teachers', 18

Colonial mats, 105

Coping saw, 120

Corn huslis, 136

Crepe paper work, 116

Crocheting, 100

hairpin, 100

Cross stitch worli, 214

Crown knot, 85

Cup, 112

Cut out dolls, 114

Cutting paper, 114

Dixcixg, rhythmic, 58

Defective, mental, 199

Dementia, 25, 28, 214, 219

pracox, $25,33,35,45,10 \mathrm{~s}$, 201

Depression, 27, 28, 119, 198, $204,209,219$

Developing occupation, 100 . $156,199,218$

Director of occupation, 34

Doll clothes, 214

liammock, 101

string, 91 
Dolls, cut out, 114

Dominoes. 58

Irawing, 192

Duster, shoe, 92

Emiromint, 217 stitches. 215, 216

English literature, 46,47

Envelope. 112

Etched metal, 204

Excitement, 25, 28

Exercises, physical, 51

FE.1R, 45

Figure-of-eight knot, $\$ 3$

Figures, string, 60

Fish's month. 112

Fob, watch, 96

Folding paper, 111

Friends' Asylum, 14

Fuller, Chief Justice, 23

G.unes, card, 55

Gardening, 174

Grass, sweet, 136

Guard, watch, 96

H.Amix crocheting. 10 o

Ifammered metal, 202

Ilammork, doll's. 101

Ilandles. basketry, 146

Henry Phipes Psychiatric

Clinie, 19

Historical, 11

Hoblies, value of, 21

Honeysuclie vines, 13 ;

Hoolied rug, 108

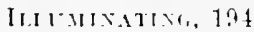

Imbereifity, 115, 214

Intian liankets, 14:

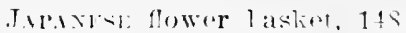
Jowelry. 201

Iolms lloptins Hospitat, 1!

Kithori, 100

ralit. $5+1$

spoul, sy
Knot, crown, 85

figure-of-eight, 83

overhand, s2

reef, 83

sailor's, \&3

Solomon's, 86

square, \&:3

true, 83

wall, 85

wearer's, $\$ 4$

Knotting, 81

L.A(E weaving, 109

Lavendar. 17\%

Leather work, 205

IICLex Hospital, 12

Macramé. 92

bag. 97

Madeira fruit basket, $14 \mathrm{~S}$

Maiden hair fern stem, 136

Making rugs. 10\% sweet jar, 176

Mass. General Hospital, 16

Mats, colonial, 105

Mechanism of recovery ly occupation, 27

Mental defective, 199

Metal, etched, 20I

llammered, 2it?

pierced or sawed, 201

punched. 200

work. 200

MInsic, 2.5

Natrin: study. 178

Nedlework, 211

Netting. 14it

Nenrasthenia. 45

Nip. 82

Nurse in hospila?, it

Ocerperme rard. 86

developing, low, 15i, 1:4, "1s

lireselor of, : :t

merhanism of recovery by, 27

psycho'ogy of, 24 
Occupation, purpose of, 25 rules of, 227

Overhand knot, 82

Paintixg, 192

Pamphlet binding, 159

Paper, black line, 223 board, 120 crepe, work, 116 cutting, 114 folding, 111 sepia, 224 wall, 117 work, 110

Paste, 117

Patch work, 218

Petals, rose, 175

Photographs, tinting, 223

Photography, 222

Physical exercises, 51

Picture puzzles, 128

Pierced or sawed metal, 201

Plaster casts, 187

Plastic work, 185

Printing, 199 block, 184

Prints, blue, 223

Psychiatric Clinic, Henry Phipps, 19

Psychology of occupation, 24

Punched metal, 200

Purposes of occupation, 25

Puzzles, 38 picture, 128

Pyrography, 210

Quits. sewed-on, 218

R.iris. 134 bax, 97

Rake linitting, 91

Reading, 42

Records, 37

Reed, 133

Reef linot, 8.3

Rewards, 35

Rhythmic lancing, 53

Rose petals, 175

Rug, hooked, $10 \mathrm{~s}$
Rug making, 107

SAILoR's knot, 83

Saw, coping, 120

scroll, 120

Schedule, 26, 35

Science, Christian, 46

Scrap book, 160

Scroll saw, 120

Seizing, 86

Senility, 108, 190

Sepia paper, 224

Serving, 86

Sewing, 213

Sewed-on quilts, 218

Sheppard and Enoch Pratt Hospital, 16

Shoe duster, 92

Shut-in personality, 45

Solomon's bar, 95 linot, 86

Splints, wood, 135

Spool linitting, 89

Square linot, 83

Stabbed binding. 160

Stamp collectins, 167

Star, 112

Starch beads, 188

Stenciling, 179

Stevenson, Robert Louis, 21

Stitches, basketry, 151 embroidery, 215, 216

String doll, 91 figures, 60 work, 59

Study, nature, $17 \mathrm{~s}$

Sweet grass, 136; jar, making, 176

T.sine, bed, 1:1

Tatting, 100

Taunton State Hospital, 18

Teachers' college, is

Tidies, 105

Tinting photograpls, 22:

Toboggan eap, 102

Tracy, Miss, 15, 16

Trick, card, 56

True linot, 83 
Turl's head, 86

Urica State Hospital, 119

Vexftax iron work, 203

Vines, honeysuckle, 136

WALL knot, 85

paper, 117

Watch fob, 96

guard, 96

Weaver's knot, 84

Weaves, basketry, 141

Weaving, 101

lace, 109

Willow, 134
Wood splints, 135

work, 119

Work, applique, 217

bead, 219

cement, 189

coil, 150

crepe paper, 116

cross stitch, 214

leather, 205

paper, 110

patch, 218

plastic, 185

string, 59

Venetian iron, 203

wood, 119 

University of California SOUTHERN REGIONAL LIBRARY FACILITY 305 De Nave Drive - Parking Lot 17 - Box 951388 LOS ANGELES, CALIFORNIA 90095-1388 Return this material to the library from which it was borrowed.

HOY $0, \cdots$ 


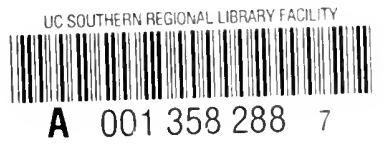


